DE KINA-B00M

urr

ZUID-ANERTKA OVERGEBRAGT

NAAT

JAVA,

ONDER DE REGERING

VAN

KONING WILLEM III.

Medegedeeld

door

W. H. DE VRIESE, Rideler der Orrle van den Nederl. Lecur, l'hil. nat. \& Afeclicinae Doctor, Iroogtecrar aan 's Rijks Hoogeschool te Lciden, Lid ran te Koninkl. Akademic yan Wetenschappen, enz.

$R D, Y C \cdot 221$

C. W. MTELTNG. 1.855 .

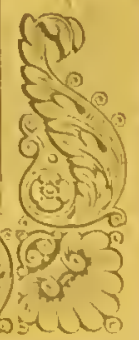




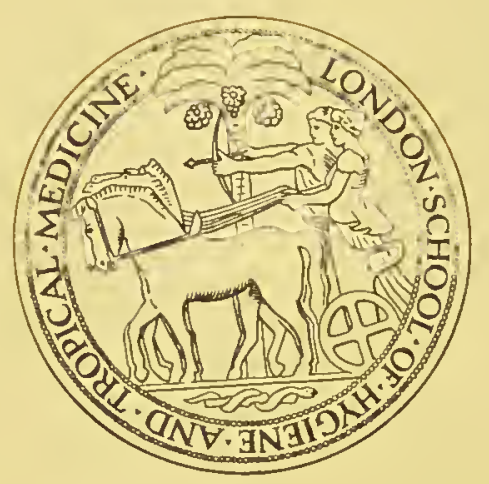

\title{
LIBRARY
}

\author{
Date 5 th January, 1959 \\ B.P.D.YC. $221 \quad 50988$
} Class Mark ....... 1855 


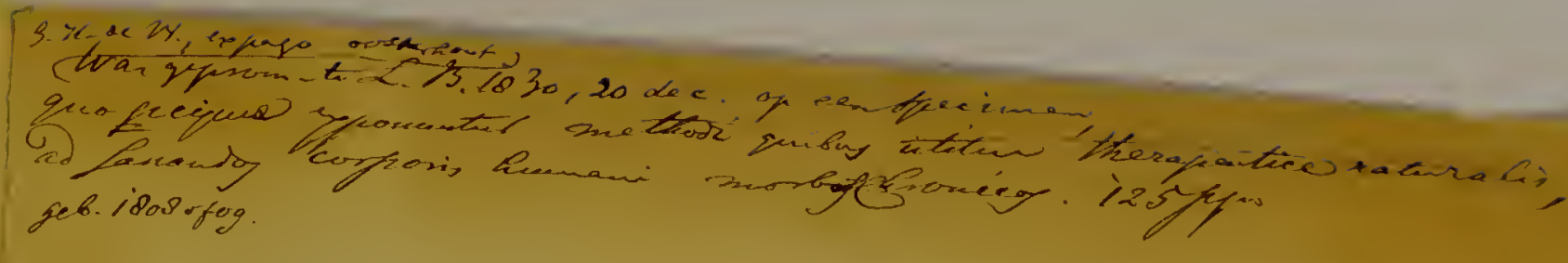

$$
\begin{aligned}
& \text { Inr. 2. Parce Veutury } \\
& \text { aren een, } \\
& \text { Trek. } \\
& \text { spoburand }
\end{aligned}
$$





\section{DE KINA-BOON}

urr

\section{ZUID-A MERIKA OVERGEBRAGT}

NALl

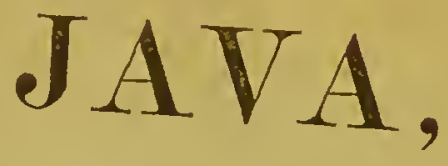

ONDER DE REGERING

$\mathrm{V} \perp \mathrm{N}$

\section{KONING WILLEMI III.}

\section{Medegedeeld}

door

W. II. DE VRIESE,

Hooslecrar an 's len Nerlerl. Lecuw, Phil. nat. \& Nedicinae Doctor.

Akademic van Wetensehappen, Lid van de Loninkl.

$$
\begin{aligned}
& \text { 'S GIRAVENILAGE. } \\
& \text { C. W. MIELING. } \\
& \text { 18.5.5. }
\end{aligned}
$$


"Ce médieament, le plus préeieux de tous eerux que possède l'art de guérir, est une "des plus grandes eonquêtes faites par l'homme sur l'empire végétal. Les trésors que "le Pérou renferme, et que les Espagnols eouraient y arraeher du sein de la terre, "ne penvent être comparés, sous le rapport de l'utilité, avee l'éeor'ee de l'arbre à "quinquina, qu'ils y reeucillirent aussi et qu'ils dédaignèrent ou ignorèrent longtems.... "Il n'est point d'épithète qu'il ne justifie, lorsqu'il est manié par des mains habiles " et qu'on en fait un usage éelairé. On pent trouver à l'opium, à l'ipeeacuanhe, au "muse, ete. des suecedanés. Nous n’en eonnoissons point qui puisse remplaeer la pro"priété la plus remarquable du quinquina, qui puisse, eomme lui, arraeher des bras "de la mort l'homme dévoré par une fièvre pernieieuse, qui montre plus puissamment "les ressources ct l'habilité de l'art de guérir et qui le veuge mieux de ses injustes "détraeteurs. "

Laubert, dict. d. sc. méd. 1820. 


\section{AAN DEN LEZER.}

De overbrengst van den boom, dic het lostbatarste van alle geneesmiddclon van hel gehccle plantenrijle oplcvert, nit Zuid-Amerilat naar het eiland Java, verdicnt in de geschicdenis der linllunr, wat meer is, in die der humanilcit, als cen gowiglig foit to worden angeleckend.

IIct belang der zaak maakit het wenschelijk, dat dit ondorwerp, reeds zoo dikwerf openlijk besproken, in zijne bijzondcrheden worde wit cen gezel en can het licht gebragt.

Ili ben overluigd dat mijne Landgenoolen, dic gewoon zijn clle. poging, lot heil der menschheid en de bevordering van waren voorvilgang on beschaving ondernomen, op prijs te stcllen, met welgevallon zullen vernemen, wat or in de laalst verloopen jaren, op last des Koxrsas, onder de leiding van den legenwoordigen Minisler van Koloniën, ten anuzien van de bedocldo overbrengst is lol stand gebragl.

It heb hel gewaagd daartoe mijne zwakke pogingen to beprocren.

Dic laak was nich gemalikelijli. It mecnde clat hel, lot regle waardering van helgeen verrigt is, nc-ly was, de kina-liwestir voor het beschaafd publick wil ecn 10 zellen, zonder mij al te nilshitend op het gebied der webenschap te howeyen. Hon aal dhs willen inzion, dat dil geschrift niel bepardelijk voor de golector 
Wereld bestemd mocst zijn en dat het, nit dion hoofde vooral, diliwerf mocijelijli was om sleeds hel juiste standpme to bewaren lussehen eene te oppervlakkig populaire en cene le streng velonsehappelijlie behandeiing.

IIel tweede gedeclle is van geschiedlinndigen aard. It had het voorregl, bij de zamenstelling daarvan, de offeiële beseheiden bij het Ministerie voorhanden, mij velwillend door Z. E. den Ileer Minister van Koloniën ten gebruile loegestaan, te launnen raadplegen. Ili bied daarvoor Zijner Excellentie cerbiedig mïne dankbctuiging aan. Il vleije mij van die bronnen cen nullig en gepast gebruilk te hebben gemaalit, waardoor dat gedeelle van dil stulije, helgeen nit zijnen aard hel meest belangrijlie moest wezen, zijne waarde heeft verliregen.

Ili beveel, voor 't overige, mijne poging aan hel billijk oordeel en de velwillendheid mijner Landgenoolen aan. Indien zij zullen lellen op mijn doel, de vermelding en de handhaving van den reglmaligen room van het ons zoo dicrbaar Nederland, in eene $\approx 00$ nilersl gewviglige zaak, - dan zal ik mij welligl zelfs mel eenige loegevendheid mogen vleijen voor de leemlen, die ongelwijfeld hier en daar mijn opslel zullen aankleven.

Leiden.

Augustus 1855

IV. II. de Vriese. 


\section{IDE KINA-KIVESTIE, IN EENIGE TREKKEN, OP HAAR 'TEGENIVOORDIG STANDPUNT'.}

Seder't de ontdekking van de Nienwe IVereld helıalden de Volken van het reeds beschaafdere Europa op die van het, in dit opzigt, nog jeuglige Amerika, eene reeks van overwinningen, die door schilterende feiten zijn gekenmerkt. - Hunne vloten doorkliefden de zceën en kecrden, met de schatlen van den school der aarde of van hel groeijend rijk beladen, thuiswaar's: maar die niel zelden waren afgeperst of verkregen ten lioste van lıel geluk en hel leven van onschuldige, soms weêrlooze volken, loor 't geweld van wapenen ten onder gebragt. Zoo lionden Beheerschers van destijds maglige Staten zich heroemen, dat in lıu gebied de Zon nimmer onderging; zoo zag nucn de Vorslelijke paleizen van KareL V le Madrid en te Tolcdo verrijzen, lol wier houw alleen de ophrengst der helasting op de suilier op Hispaniola (hel tegenwoordige St. Doningo), gedurende weinige jaren, was voldoende goweest. Zoo werden de Vorsten en Staten van het toenmalige Europa allengskens werkelijk de Beheerschers van deze nog hetrekliclijli voor liorl onllekte Rijlien :an gene zijde van den Oceaan; zoo scheen inderdaad hoe langer hoe mecr de Nicuwe aan de Oude Woreld te bchooren. 
Er slaat in de geschiedrollen van die tijden menigr feil vermeld, wat men tot eer der menschlieid liever zon weuschen voor altijd te zien uilgewischt. - Milar, geen wonder voorwailr, zij bevalten tevens de vermelding van menige schoone en nutlige ontdekking, die van eene groote waarde is voor onze kcnnis vau landen ell volken, van voortbrengseleu en hunne aanwenling, waarvan zells de incest verwijderde Staten, door hun onderling verkeer, groute voordeclen hebben getrokken.

Amerika, eerlijus bijna geheel en al door de Oude Wercld bchcerscht, lieeft zich voor lich grootste gedeelte aan Europa's magl ontlrokken. - Europa evenwel gaat niellcmin voort mel het maken van veroveriugen, maar van eenen geheel anderen aard als voor dezen. - Ilel ziju noch vloten die met vernieling bedreigen, noch legers die bloedige vanen ontrollen; het zijn geene overweldigingen door hel zwaard en verwoesting; necn, het zijn bovenal veroveringen op het gebich van kennis en beschaving in alle takken van de welenschap der natuur, dic der menschheid tot eere zijn.

Aan de spits der aanvoerders en overwinnaars in dien edelen zin staal in de negentiende ecuw de onovertroffen von llunbolut, «als een andere Alexander, die Anerika niet door wapenex, " maAr cay het gerien van den menscuelijken geEst heEet o. "DERworpen» ell aim wien men, zeker mol groot regl, den naam van DEN Groote kan lockennen.

Hel was in dicuzelften zin dat Nelerlaul al rroeg zijuc lotrekkingen met overzesche landen; zijue hindelsonderneningen, 
zijne togten naar de meest verschillende en meest verwijderde zeeën en landen, wist dienstbaar le maken aan wetenschap en heschaving, en hel behoefle, in dit opzigh, voor geene natie ter wereld onder te doen. - Een Houtman, die liet eerst naar OostIndië reisde, bepaalt onderscheidene zuidelijke sterrenbeelden en doet eene ouschatlsare dienst aan de wetenschap en de zeevaartkunde; de namen van Lemane en Schoutey en van Abel Jasssen Tasman staan te regt als die van de grootste ontdekliers opgeteekend, en de logt van Banentz en zijne wakkere zeelieden werd meermalen mel dien van Americo Vespucius en Kolumbus vergeleken (1).

Het Plantenrijk van Oost-Indië, vooral ook in zijne nultige strekking, werd 'l eerst door Nederlanders nagegaan en de slotsom valı hel onderzoek, in kostbare geschriften wereldkundig gemaakt, die daarvoor nog heden eenen voornamen grondslag en eene rraagbaak uitmaken; - terwijl de togt van Msunits vay Nassau naar Brazilië tevens, door Marggraf en Willey Piso, de eerste aanleiding werd tot de betere kennis van lietgene, wat dat deel der Nicuwe Wereld oplevert.

Nederland is in gelijken zin steeds voortgegaan om lienmis aan de natuur in vreemde en overzeesclie landen, ten nutte van eigen landaard of van de geheele menschlieid te doen opsporen. Het behoeft, in dit opzigt, zelfs bij grootere en nuecr magtige Staten, niet acliter te staan.

(1) MoLL, verlt. over cenige vroegere zeetogten der Noderlinders, 1825. 
De latst verloopene jaren hebben daarvan een nicuw lewijs geleverd, door de overbrengst van den kostbaarsten boom, dieu

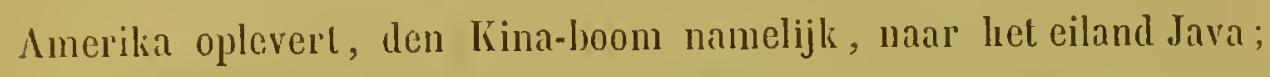
eene gebeurtenis welke in hare aanleiding, bijzonderlıden en mogelijke of vermoedelijke gevolgen wel verdient te worden aangeteekend.

Ik acht let nuttig en pligtmatig om het mijne bij te dragen, opdat voor de geschiedenis bervaard blijve, wat, in dit opzigt, Nederland tot eenen altijddurenden roem zal verstrekken. Indien mijne pogingen daarloe te kort zullen schieten en mijne roorstelling niet geheel zal beantwoorden aan de hooge waarde van lıet onderverp, - zeker zal het mij aan ingenomenheid inet deze voortreffelijke zaak niet ontbreken.

Ik anvaard deze taak met de overtuiging, dat ik meer dan gewone toegevendheid behoeven zal en al heb ik ook geenerlei regt om daarop te rekenen, - ik houde mij toch verzekerd dat de Nederlandsche Natie deze mededeeling met belangstelling aannemen en met erkentelijklıeid vernemen zal, wat onder de Regering van Kosing IVILeEM III, door een verlicht Staalsman, tot heil del menschlseid, in dil opzigt, is lot stand gebragt.

Omstreeks het midden der zeventiende ceuw werd in Europa een geneesmiddel bekend, lietwelk toen reeds als een der meest gewightige en meest nullige beschouwd werd en waar aan $10 \mathrm{~g}$ heden ten dage, na meer dan twee eeuwen, eene toenemende belangstelling ten decl valt. 
Ik bodocl den lina-hast. Ilet is voor den geregelden zamenhang van hehandeling van ons onderwerp en tot juiste waardering van het feit, hetwelk de hoofdzaak dezer mededecling zal uitmaken, noodig, zijne geschiedenis hier in korte trekken te schetsen en in cen onderling verloand te beschouwen.

Het juiste tijdstip van den invoer van de Kina in Europa wordt door von Iunbolot gerekend te zijn het jaar 1640 (1); terwijl uit andere mededeelingen met eenigen grond zou zijn op te maken, dat dit acht jaren vroeger en dus in het jaar 1652 zou wezen. Die onzekerheid is echter ligtelijk te verklaren. Nieuwe produkten vinden dikwerf geenerlei goedkenring en, in vele gevallen althans, niet dadelijk den bijval, dien zij waardig zijn, en de eerste oirkonden aangaande dezelve zijn daardoor vaak als in nevelen gehuld.

Zoo mag het ook met den Kina-bast gegaan zijn.

Niet minder onzeker zijn en bijna aan liet fabelachtige grenzen de berigten, of zal men liever zeggen legenden, wegens zijne ontdekking zelve, waaromtrent men de mededeclingen ran Grofhroy (2), von Humboldt en anderen kan raadplegren. Zóóveel echter kan men als waarsclijnlijk aannemen, dat de inboorlingen van sommigge deelen ran Zuid-Amerika, reeds róór de annkomsı der Spanjaarden in dat Werelddeel, de Kina hcbben gekend en tot genezing van tusschenpoozende koortsen heblben aangewend. In andere gedeelten van Amerika daarentegen schijnen de in-

(1) Alex. vox Ifumbond, ucher die Chimi-Wakler, in Berl. Mag. s. 59.

(2) Traile de la maliene mélicale, II. 73. 
landers de líina weinig of niet te hebhen gekend, noch geacht. Vos Hunionot toch heeft streken bezocht, waar de koortsen in ongewone mate heerschten, terwijl de lijders liever stierven dan dat zij den Kina-bast gebruikten.

Eene door lıet gezag van de La Condamine (1) en van andere geloofwaardige schrijver's bijna authentiek geworden en in alle populaire geschriften over dit onderwerp herhaalde mededeeling wegens de eerste toediening van den Kina-bast aan de Onder-Koningin van Peru, de Gravin dec Ginahon, is te bekend om hier te worden lierliaald. Aan de juistheid daarvan wordt door voN Hunвoldt getwijfeld, wien het echter als waarschijnlijk voorkomt, dat door die aanzienlijke Vrouw let poeder van den Kina-bast omstreeks 1640, na hare terugkonst van Peru, het eerst in Europa is verbreid geworden.

Ééne zaak verdient daarbij echter onze opmerking: lıet is namelijk deze, dat de bast, welke aan de Gravin dec Cincuon zou zijn toegediend, van Loxa afkomstig en dus welligt die Kinasoort kan geweest zijn, welke in latere jaren in den Europeschen lıandel als Loxa-Kina is onderscheiden geworden; anderen echter louden het voor waarschijnlijk, dat dit de roode Kina kan geweest zijn, die, blijkens de mededeclingen van DE LA Condanne, ook in dezelfde streek van Loxa voorkomt; welk gevoelen, om het altijd zeldzamer voorkomen van de roode Kina, mij minder aannemelijk voorkomt.

(1) Sur l'arbre de Duninquini. Mcém. de l'Acad. Royale des Sciences de l'aris. 1738. 4. ग. $226-243$. 
Na hare hekendwording in Madrid, schijnen er al spocdigy niente en groote aanvocren te licblen plaats gehad, doch is de Kina in Europa nict in gelijke mate in roem gestegen, als zulks in Spanscl Amerilia het geval was. Dit lad ecrst later plaats.

In Italië, vooral in den Kerkelijlicn Staat ingevocrd, cn daar op Hoog Gezag onderzochı en aanbevolen, vond lıaar gelıruik geen tegenstand meer en werd zij wcldra van daar over gelıcel Enropa verbrcid. Het is ons niet duidclijk, welkc de eigcnlijkc oorzaak gewecst zij, waardoor de Kina later in hare schatting cen tijl lang is gedaald; maar nict onmogelijk, zelfs cenigermatc waarschijnlijk is het, dat de grootc aanvragen uit Amcrika recds destijds, aanleiding hobben gegeven tot het inzamelen van allerlei basten, waaronder er welligt geweest zijn, die geencrlei genecskrachtig vermogen liadden en wier aanwending dus gcen ander gevolg dan een wantrouwen in dit geneesmiddel kon to weeg brengen.

Daaraan hragt nict weinig toc cenc nict gelukte of althans onvolkomene genezing van LEOPOLD, Aartshertog van Oostenrijk, Gouverneur der Oostenrijksche Nedcrlanden, dic zijnen lijfarts Cinflet opdroeg dit geval tc hockstaven en der wereld lict gebruik van dit hedriegclijkc genecsmiddel tc ontraden. - Zijı geschrift, dat in 1655 verscheen, maakte grooten opgang en werd door cen aantal anderc van gelijke strekking, maar dic in nog meer lıcvige verklaringen vervat waren, gevolgl, als wilde men de maatschappij tegen cenc pest dic haar bedreigde, waarschuwen.

Ilet onlbrak echter ook nict aan voorstauters van dit Godde- 
lijk geneesmidlel. Ook hume namen en geschriften zijn hij de sehrijver's over dit onderwer'p vermeld. In enkele Staten breidde zieh, nietlegenstaande de waarsehuwingen daartegen, het gelıruik in die mate uit, dat men toen reerls klaagde over lict gelorek aan genoegzamen roorraad.

Amsterdam, Brussel en Rome sehijnen vroeger (ongeveer in 1661) de plaatsen, waar men de Kina bovenal kon verkrijgen, te zijn geweest. Weldra kon men laar ook tc $\Lambda$ ntwerpen, cn naar mate de tegenstand meer en meer weck, mede in de Fransche handelsteden bekomen. IIet bleek daarna al spoedig, dat sommige geheime geneesmiddelen tegen de koorts, tot hoogen prijs verkocht, werkelijk uit Kina bestonden.

Om de Kina in haren reglmatigen roem te herstellen, was niels meer afdoende dan de herstelling van den Dauphin, later LodewiJk XIV, door TALBor's (of TALBoT's) arcanum, dat cigenlijk Kina was; welk areanum voor eene groote som gelds en cen jaarlijkseh pensioen, den cigenaar door de Fransche Regering werd afgekoeht. Er ontbrak sleehts aan, dat zelfs diehters den lof van het hoog gewaardecrde geneesmiddel hezongen en dat con Condé en een Counert aan de toediening van de Kina het behoud van hun leven hadden te danken.

Er sehijnt intussehen aan een cigenlijk wetensehappelijk onderzoek in de cerste tijden van het bekend worden van de Kina, zelfs niet gedacht te zijn. Men kende van het kosthare geneesmidden niets anders, dan dat liet de bast van cenen Perunanschen boom was. - Maar van dien hoom zelven kemle men volstrekt niels. 
Laat ons in korte truken nagaan, hoe dit wetenschappelijk onderzoek aangevangen, allengs toegenomen en uilgebreid is, on daardoor op lıet tegenwoordig standpunt der krwestie te kunnen komen.

De ecrste wetenschappelijke narigten omtrent den Kina-hoom zijn wij verschuldigd aan eenen wis- en sterrekundige, Cirances Marie de la Condanine. Hij was door de Fransche Regering, mel eenige andere geleerden, naar Zuid-Amerika gezonden, onı daar in Zuidelijke rigting de lengte van eenige graden van den meridiaan van Quilo te bepalen. - In zijn relaas vinden wij omstandiglıeden vermeld, welke door latere reizigers niet herhaald zijn en waarvan er daarom hier enkele worden vermeld, omdat zij, iı betrekking tot de tegenwoordige mededeeling, van eenig helang kunnen worden gerekend (1).

Volgens de la Condanine, was destijds Loxa of Loja eene lileine stad, die in 1546 door de Spanjaarden gebouwd, ongeveer 70 mijlen zuidelijker dan Quito en op eene hoogle van 800 toises gelegen is. Het klimaal is zacht, de litte wel sterk, maar niet ondragelijk. - De beste Kina, zegl hij, is die van den berg Cajanuma, op $2 \frac{1}{2}$ mijl afstands van Loxa. - Van die plaats zou de eerste Kina naar Europa gehragt zijn; nog weinige jaren te voreu voorzagen zich de kooplieden, die dezen bast in den handel bragrten, van een notariëel certilicaat, tot hewijs, dat hij te dier plaatse was ingezameld.

(1) De ta Cononmes, Relation abrigée d'un voyage fail dans l'intéricur de l'Ameringe móridionale, al Piaris 1745. 8. 1. 26, 27. 203. 
Op den $3^{\text {den }}$ Februarij 1737 bragh we ua Conbsure den nacht door op den top van dien berg, in de woning van een der Kinainzamelaars; hij had op dien logt het voorregt de Kina-boomen te zien, hij maakte eene schets van eenen tak met bloemen op de plaats zelve, even als van de vruchlen, Die (gelijk hij zegl) or alLe tiJden VaN Het JaAR te Zien ziJN.

De la Connamine werd daar ter plaalse reeds opmerkzaam gemakt op hel verschil van soorten, de witte, gele en roode Kina-soor', hebbende, volgens aan hem gegeren informatien, de boomen van welke de beide laatste afkomen, zelfs geenerlei verschil in de bloemen, vruchten noch bladen en ook uitwendig niet in den bast. De onderscheidene soorten groeijen veelal naast elkander.

In de vlakten (dus gaal de la Condanine voort) komt de Kina. boom niel voor, en evenmin behoort hij tol de gezellige planten, dat is, dezulke, die tol eene en dezelfde soort van gewassen behooren en in grooten gelale bij elkander groeijen. Hij steekt boven andere hem omringende boomen uit. Laat men den loom groeijen, dan ontwikkelt hij zich tot eene soms enorme dikte als van eens mans midden, maar de gemiddelde dikte is $8-9$ dıim. Zóo enorm dik vond men de Kina-boomen echter, tijdens hel onderzoek vau de la Condanne, op dien berg, die de cerste Kina voor Europa heeft opgeleverd, niet meer; al die oude boomen waren, nadal men ze geheel en al ontschorscht had, gestorven; men heeft daarentegen bevonden, dat sommige jonge boomen door dic behandeling ook sterven, mar ditismel helgrootste antal niet liet geval. De groote consumlic heeft te weog ge- 
bragt, dat men er destijds slechts weinige boomen meer vond. Dikker daı een arm zag men er zelden, en meestal waren zij niel hooger dan 12-15 voeten. De afgesneden stronken loopen weder uit. Het schillen kan op alle tijden des jaars geschieden, zoo men slechts zorg drage den last beloorlijk te droogen. De inzameling van de zaden, in hunne volkomen rijpheid, is uiterst moeijelijk; door' 't uildroogen van de vruchten sterven zij allengskens; de wind doet ze verstuiven, en zoovind $t$ men slechts ledige viuchten aan de takken.

DE la Coydamine was de eerste en, voor zoo ver wij weten, de eenige, die eene proeve heeft gedaan om jonge Kina-boomen levende naar Europa over te brengen. Toen hij in 1745 Loxa voor de tweede maal bezocht, en zijne rigling nam naar den Amazonenstroon, verzamelde lij jonge uilloopers van Kina-boomen en vond lij, vergezeld van twee Indianen, dire hem tot gidsen verstrekten, na veel inspanning, gedurende eene geheele dagreize, niet meer dan acht of negen jonge planten, die hem tol dil oogmerk konden dienen. Hij liet deze in kisljes met aarde zetlen en met groote voorzigligheid dragen naar de plaats waar ze moesten tworden ingescheepl. Langs eenen moeijelijken weg van 1200 mijlen (Lieues) werden ze met alle mogelijke zor'g beliandeld, en toch moest hem het onbeschrijfelijk leed te beurt vallen, dat alle zijne jonge planten door éénen golfslag verloren gingen; namelijk werd bij Cap d'Orange ten Noorden van P'ara, de canol, in wellie ziclı de boompjes bevondeı, overstroomd, waardoor zij met lict zwalkie vaartuig verzonken. 
Bij zijue amkonst te Cayenue werden proeven genomen met het uitzaaijen van zaden van Kina-planten (of Cinehonen), welke echter niet opkwamen, niettegenstanade zij sleehts acht maanden oud en dus ter kieming nog geschikt geneht waren. Zoo verdween vool ne ta Condanine de laatste hoop om liet verlies van zijne planten te herstellen.

In 1759 , dus bijna gelijktijdig met de ta Condanine, werden de Kina-streken om Loxa, even als die van het hoogere gedeelto van Peru, bezoelit door Joseri de Jussieu. Door hem leerde men wel eenige soorten van dit plantengeslaeht kennen, maar vaı zijne waarnemingen aangaande de historie van de Kina, is bijna niets bepaalds in het licht gekomen (1).

Zijne soorten heeft later Linnaeus als ééne soort, de Cinchona officinalis, hesehreven; doch vox Humbozde lieeft de eene later onderzoeht en als zijne Cinchona Condaminea bekend gemaakt en de andere als Cinchona cordifolia Mutıs erkend.

De Jussieu maakte de autoriteiten daar ter plaatse en in de provincie Quilo opmerkzaam, dat men bij let sehillen de soorten van bast moest niteenhoudeu en vooral de beste onder deze naar Europa zenden.

De Kina begon intusschen meer en meer de aandaelit der be-

(1) Een kort verslag daarvan vindt men in de Ilistoire de la Société Royale le Mélicine, anno 1779, grelitelel: Réllexions sur deux espéces de Quinquina, lécouvertes nouvellement aux environs de Sinta lé, daus l'Amérique méridionale. 
selıaafde wereld op te wekken. -- Ifet was namelijk dertig jaren later, dat bijna gelijktijdig ıvee wetensclıappelijke expeditiën, tot onderzoek van de Kina-boomen, naar het Zuidelijk Peru en en in Nicuw Grenada werden ondernomen. Aan het hoofd van de cene was José Gelestino Mutrs en aan dal van de andere stonden de bekende kruidkundigen Ruz en Pavox.

Ioe geheel anders waren de omstandigheden, onder welke, in die tijden, deze onderzoekingen werden ondernomen en begunsligd. De landen, welke toenmaals onder het gebied van Spanje stonden, zijn thans wel onafhankelijke republieken, maar waar burgeroorlogen onafgebroken elkander opvolgen; waar men zich om beurle te vuur en te zwaard de opperste magt betwist en waar de legers, die tegen elkander optrekken, den natuur-onderzoeker lijna bij clke schrede mel gevaar voor zijn leve! hedreigen.

Er zijn geene door de natuur meer gezegende oorden, dan die van hel zongenaamd centraal en tropisch Zuid-Amerika; er zijn er tevens geene, die, door 's menschen toedoen, tot eene grooterc diepte van cllende zijn gezonken. De natuur-onderzoekers in de vorige eeuw hadden, wel is waar, met groote moeijelijkheden te strijden; maar zij ondervonden van de Spansclıe bevolkiugen der onderzochte landen slechts hulp en medeverking en hadden dus, althans van die zijde, geen hinderpalen of wantrouwen te vreezen, hetgeen zoo vaak den reiziger van wege inlandsche bevolkingen Ien deel valt.

Dit is volstrekt van loepassing geweest op de expeditiën van ne ta Coninune, van Mutis, die Nieur-Grenada onderzocht, en ran Ruı en Pavos, dic eenige jaren later, omstreeks 1777 , zich naar Peru beblon begeven. De Spaansche Regeringen in deze gewesten on- 
dersteunden met alle mogelijke hulpmiddelen die ondernemingen, waarvan men zich zóo veel vruchıl bcloofde; en, niellegenstaande deze gunstige omstandigheden, hebben zij loch niet in allen deele aan de verwachting beantwoord.

Mutrs ontdekte in 1772 dat de Kina ook groeide in de nabijheid van Santa Fé de Bogota en wel in hel bosch van Tena, nabij de helling der gebergten van Santa Fé. Hij vond die een jaar later tusschen Honda Guaduas. Toen in het jaar 1773 de Onderkoning van dat Rijk den Magdalena-stroom opvoer, overhandigde Muris aan denzelven, als een nieuw ontdekt en hoogst kostbaar bewijs van de voortreffelijkheid en de vruchthaarheid van het land, eenen hloeijenden tak van eenen Kinaboom. Hij schijnt zelfs plantagiën van de Kina te hebben aangelegd en de eenige geweest te zijn, die ooil Kina gekultiveerd heeft.

Hij heeft de volgende soorten in het Koningrijk Nieuw-Greneda ontdekt.

I. Cinchona lancifolia Mut.

(C. Condaminea Lamb. var. \& lancifolia sec. IVedo.)

Van deze stamt: volgens Muris, de Oranje Kina af. Hij neemt aan, dat de bast, dien de inlander's Calisaya noemen, ontwijfellaar tol deze soort behooren moet.

II. C. cordifolia Mur.

Van deze komt, volgens Murss, de gele Kina van Nieurv-Grenada.

III. C. oblongifolia Mu'T.

(Cascarilla magnifolia \& vulgaris IVEnn.)

Dit zou de moederplant zijn van de roode Kina va Nieuw-Grenada, die in dal land zeer gemeen zou we\%en. 
IV. C. ovalifolia Mut.

(Cascarilla macrocarpa WEvb.)

De wille kina van Nieuw-Grenalla.

Zijnde alzoo III en IV, volgens de nieuwere onderzoekingen, geene eigenlijke Cinchonen.

Men verlieze hierbij vonral niet uit het oog de onschatbare ontdekking van Mutss, dat een der Kina-boomen door hem ontdelit en in de wetenschap als Cinchona oblongifolia bekend geworden, de roode lina van Santa Fé de Bogota oplevert, waarvan let bestaan als eene eigene soort van Kina-bast, later door WEDDELL ontlend is en ook zelfs, volgens de berigten, door de inzamelaar's aan DE LA Condunine in der tijd gegeven, twijfelachtig zou zijn.

Ik kom welligt hierop nader en elders terug, omdat ik, tot. hetere overtuiging, de zienswijze van den Heer WedDeLL, op het punt van roode Kina, als zijnde geene eigene bastsoort, nog niet geheel kan bëamen.

De uitvoer uit de havens van Nieuw-Grenada, vooral uit Carthagena en Santa Martha, werd een noodzakelijk gevolg van de ontdekking van Mutıs, dal de bosschen van Nieuw-Grenada de Kina opleveren; terwijl zij sedert niet meer nitsluitend uit de ha. vens aan de Zuidzee gelegen en in de rigting om Kaap Hoorı behoefde verscheept te worden.

Sedert 1780 had de uitvoer naar Spanje, Noord-Amcrika en Engeland reeds uil meerdere lavens, als b. v. Lima, Payla. Guayaquil, Buenos-Ayres, Carthagena en Sanla Martha plaats. Maar van dat tijdstip af dagteekent ook de rermenging van gnede. 
basten met die van mecritere soorten en geheet indere gestachten van planten. Aan vervalschingen, door ondergestoken hasten, scheen het al mede niet te ontlureken.

Ten laatste wilde men geen Kina nit Nieuw-Grenada meer en liet ontbrak zells niet aan de buitensporigste middelen on de soorten uit dat Rijk te weren. Men liet cens op Hoog Gezag, te Cadix, eene aanzienlijke hoeveelheid van de kostbaarste basten verbranden, welke Mutis op 's Lands kosten in Nieuw-Grenada lad laten verzamelen, en men kwam van die dwaling niet eerder terug, dan nadat deskundigen en daaronder vooral de Spaansche liruidkundige ZEA, tegen het gezag van Ruz, hadden bewezen, lat de soorten van basten uit Nieuw-Grenada aan die van Peru volkomen gelijk waren.

Het oogmerk van dit overrigt kan niet zijn om alles te ontwikkelen, wat tot de opvolgende kruidkundige ontdekkingen op het gebied van de Kina behoort. Wij zouden daarloe de geschriften van de verschillende reizigers, die Amerika, met het doel om ontlerzoekingen betreffende de Kina te doen, hebben hezocht, vooral van Hiprouto Ruz, von Humboldt, St. Hilaire en anderen moeten ter hand nemen. Wij willen ons daarom slechts tot de nieuwste en voornaamsle reiziger's bepalen. Zij zijn, na vox Humroldt, vooral Poeppig (1), Tsairudi (2) en Weddell.

Helgeen, waarin de reiziger's, de kruilkundigen, de kemner's van handelswaren het meesi in gevoelen verschillen, betreft het aantal van soorten van Cinchona en van basten. Dit is noodzakelijk

(1) Reise in Peru, Chili und anf Ien Amazonen-Ströme.

(2) P'eru, Reise-skizzou aus Ilem Jalıen I. 1833-1842. II. 1856. 
eene der gewigtigste kwestiën; want daarin moet vooral worden gerekend de grondslag te zijn voor het annemen van het verschil van de waarde der basten, die in den handel, onder verschillende benamingen voorkomen. Hoc de inzigten te dicn aanzien uiteenloopen, is daartit op te maken, dat, terwijl Ruız en Pavox dertien soorten aannamen, daarentegen anderen de Kina-boomen tot vier soorten helben teruggebragt. Von Hunbolot schirift dit verschil van gevoclen toe aan de groote afwisseling van vormon der bladen, vaak aan eenen en denzelfden boom voorkomende; welke vormen, afzonderlijk of in hcrhariën gezien, aanleiding geven kumnen tot het aannemen van soorten, die niet als zoodanig bestaan. Tegen die dwaling zijn de reiziger's, die de planten in de bosschen zelve konden nagaan, meer dan andere kruidkundigen, gewaarborgd. Het beschrijven en het voorstellen van soorten naar aanleiding van planten, door anderen in r'reende gewesten ingezameld, is daarom altijd min of meer moeijelijk of zelfs onvoorziglig.

De ontwikkeling van jonge Kina-planten in 's Rijks Akademictuin te Leiden heeft mij de gelegenheid gegeven om te zien, in welke eene groote mate de vormen, in de ver'schillende ontwilikelings-perioden, afwisselen.

Von Hunbold gaf hel eerst eenige algemeene mededeelingen omtrent de gcographische verlureiding der Cinchonen (1).

De streek waarin zij roorkomen, is tevens die der Joomachlige

(1) Essai sur la géographic des plantes, accompagne d'uu ableau pliysignuc

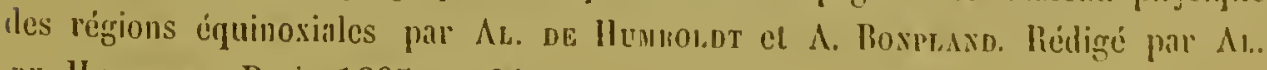
de Ilumblot. Paris 1805. p. 64. 
rarens, hoven de l'alnten en Bananenstreck. Vele soorten van Cinchonen komen op de bergketenen der Andes voor, tot op eene loogle van 8000 voeten. Enkele soorten, die gele Kina opleveren, zoo als de Cinchona lancifolia en Cinchona cordifolia Mut., seliijnen zelfs de koudere temperaturen te verdragen. De thermometer daalt daar dikwijls tot op het rriespunt. Er zijn soorten, die tot de lagere, dat is, warmere streken afdalen, en dit zijn, volgens von Honboidt, de planten die de roode basten opleveren. Van de Cinchona longifolic zag von Hunbocdt in de dalen zeer hooge stammen, die nog geen 2270' boven de oppervlakte der zee voorkwamen. De Kina van Loxa komt roor tussehen 6000-7000 roeten hoogte. (1)

De Cinchonen groeijen, volgens von Humboldt, op de Andes op eene lengle 700 mijlen van den $20^{\circ} \mathrm{Z}$. Br. tot den $11^{\circ} \mathrm{N}$. Br. Men vindt ze in groepen verdeeld. De geheele helling van dit gebergte, bezuiden Huanuco, is een te zamenhangend Kina-woud. Meerdere provinciën, als La Paz, Guailas, Huamalies, Jaen en Huancalsamba leveren deze boomen op. Men vindt ze op de westelijke helling van den Chimborazo, op de looge vlakten van Riobamba en Quilo. In de provincie Paets schijnt geen Kina voor te komen, terwijl men ten noorden van Almagriez in de provincie Papaylen, ze weder aantreft. Men vindt ze bijna onafgebroken zich uitstrekkende op de met sneeuw bedekte bergen van Quindiı en Tolima, de plateaux van Supia en de berghellingen van Mariquita, Guaduas, Pampelona, tot aan de bergen van Merida.

De bekende natuuronderzoeker Hsenke ontdekte de Cinchonen

(1) De distributione geographica plantarum secumbum cocli temperiem. Isutetiae-Paris. 1817. 1. 101. 
op een aantal plaatsen, alwaar men ze nimmer lad ingezameld. (1)

De gemiddelde temperatuur, waaronder de Cinclionen groeijen, is, volgens von Humboudt, $16^{\circ}$ R. Hierop maken Cinchona lancifolia en $C$. ovalifolia, die zeer hoog stijgen, vitzonderingen, en die alleen over dag onder eene temperatuur van $8-9^{\circ}$ leven, terwijl des nachts, uren lang, de temperatuur tot het vriespunt daalt. $C$. oblongifolia en $C$. caduciflora dalen het diepst in de valleijen af, alwaar de gemiddelde warmte tot $24^{n}$ en hooger stijgl.

De nieuwste reiziger, wiens onderzoekingen ter algemeene kennis werd gebragt, is Dr. Weddell. Hij was een tijd lang de reisgezel van den Franschen Consul, den heer de Castelnau, gedurende eene expeditie op last van de Fransche Regering ondernomen in Zuid-Amerika (2), en van wien hij zich, van Paraguay af, gedurende de jaren 1845-7, lieeft afgezonderd. Zijn geschrift over de geschiedenis der Cinchonen heeft hem te regt cene groote beroemdheid gegeven en als eene der autoriteiten in dit gedeelte der wetenschap eene voorname plaats doen toekennen. (5)

Het zij mij vergund hier melding te maken van eenige der voornaamste facta, waarvan Dr. Weddect in zijn geschrift gewaagl.

$\mathrm{Er}^{\mathrm{r}}$ is hierhoven reeds vermeld, dat de ontdekling van Mrutis, dat de Kina-boom niet verre van Bogota groeide, de aanleiding werd dat men de Kina niet uitsluitend meer langs Kaap Hoor'ı

(1) Zic zijne mededeclingen verval in: Don Felix de Azara, Voyage dans l'Amérique móriclionale, depuis 1781-1801. Paris, 1809.

(2) Expédition dans les parties contrales de l’Amérique du Sud, de Rio de Janciro à Lima el de Lima au Para, 1813-7, sous li direclion de Fraxcis de Casteinau. I-VI vol. Paris 1850-1. Ocl.

(3) Ilistoire maturelle des quinquints, nu Monographic du grenre Cinchona cle. par M. II. А. IVEduela. Paris, 1849. 
naar Etropa voerde, maar ook uil de haven van Carthagena over den Allantischen Oceaan daar henen bragt. Had nıcn uu tol het jaar 1776 waarschijılijk geenc anderc Kina-basten meer gekend dan die van Loxa, en verkeerde men in de ntecning dat benoorden den aequalor gecne Kina konde grocijen, -- er opende zich voor den lrandel en voor de genceskunst cen nieuw veld, serlcr't de scloone ontdekkingen van Mutis in Nieuw-Grenada gedaan. De Kina-streken, die nog bijna geheel en al onbekend bleven, waren die, welke zich uitstrekken achter en ten zuiden van de groote keten ler Cordillières; althans had de wetenschap weinig voordeel getrokken van de nasporiugen in dic streken door Jozeru de Jussieu, die slcchts cnkelc punten bczocht liad.

De lieer WedDeLL, overtuigd van hel gevaar, waarmedc men bedreigd wordt, dat, ten gevolge, van de groote exploitatie en consumtie, dc beste soorten, voornamelijk cchter de Calisaya- of Konings-Kina (van welke de clinine bereid wordl) zal wordeı uilgeroeid, had zich hepaaldelijk voorgenomen, om zich met een opzctlelijk onderzoek van alle Cinchonen bezig tc houden, vooral ook om daardoor de aandacht te vestigen op cenige soorten, wellie latcr welligt de betere soorten zullen mocten vervangen, en die, loczecr minder werkzame bestanddeclen bevaltende, echter, wegens haar ovcrvlocdiger voorkomen, nog cenigcrmate waarborgen tcgen lıet algeheel verlies van liet kostbaarste geneesmiddel van let gehcele plantcnrijk.

De hecr Wedoert heeft de volgende route genomen. In AugusLus 1845 kwam hij uit Brazilië, lnor het land del Indianen van Chiquitos, in Bolivia. Tot aan Santa-Cruz de la Sicrra lion hij slechts onvolkomen herigten over de Kinl hekomen. Van daar af echter 
werden dezelve al meer en meer luelangrijk, en naar aanleiding daarvan, begaf hij zich, op 't laatst van Novemher, in meer zuidelijke rigling naar de Rio Grande, langs Peray en Abapo, door de provincie Cordillera, dic van Azero, de looge plateaux van Pomabamba en de provincie Cinti tot aan Tarya, alwaar hij op 't laatst van Januarij 1846 aankwam. Deze allermoeijelijkste reize lad ten doel om met naauwkeurigheid de zuidelijkste grens van de Kinastreek (Reyio Cinchonifera) tc bepalen. De heer WEddell vond daar de allerlaatste en zuidelijkste Cinchona op $19^{\circ} \mathrm{Z}$. br., aan welken boom hij, als den zuidelijksten en in dic verre oorden afgezonderden wachter ("sentinelle retiréc») den naanı gaf van Cinchona australis.

In het begin van Augustus verliet Dr. Weddelt die streken om de groote steden van Bolivië, Potosi, Chuquisaca en Cocháhamba te bezoeken, in welke steden de handel in Kina-basten niet zeer belangrijk was; evenwel zou in Chuquisaca, de hoofdstad van Bolivië, eene fabriek van sulphas chinini tot stand gebragt worden. Ik durf niet hepalen of dit hctzelfde plan zij, waarvan de heer Tschudi gewaagd heeft (1); maar, indien dit zoo mogt wezen, dan meen ik, op gezag van dezen laatsten natuuronderzoeker, te kunnen verzekeren, dat dit plan niet tot stand is gekomen.

Van Cocliabamba hegaf zich de heer Wendelt over de hooge bergkelenen der Andes, naar de Provincicn La Paz, Ayopapa, Enquisivi en Yungas. Recls bij het hegin zijner komst in de Prorincic Enquisivi had Wenderl gelegenheid om de heste van alle soorten van Kina to, hestuderen, namelijk die, wellic de Calisaya

(1) Seru, Skizze enz; hicronter nilvocriger anogchaald. 
oplevert, zijnde de kostbaatste van alle hasten, uithoofde van de groote hoeveelheid chinine, welke daarin hevat is. Deze plantsoort, welke, tot dus verle, volgens WedDerL, bolanisch gehecl en al onbekend was, heeft hij onder den naam van Cinchona Calisaya beschreven.

De Provincie Ayopaya is, uilhoofde van hare aanzienlijke loogte boven de oppervakte der zce, bijna gelıeel zonder bosschen. Meer noordelijk, namelijk bij Palca, verhaalde men den heer WeddelL dat er bij de Rio Ayopapa een zeer uitgestrekt Kina-wond was ontdekt. In de Provincie Yungas cvenwel, de rijkste en de vruchtbaarste van geheel Bolivië, verkreeg WEDdeLL de beste narigten omtreut de wijze van exploiteren, bereiden, het verkoopen en vervalschen van Kina-basten; waartoc inzonderheid strckte een bezoek aan de steden Yrupana, Chulumani, Coroico, enz., alwaar men zich meer of min met den Kina-lıandel bezig loudt. Te Puno, Arequipa en in de omstreken van het groote meer Titicaca bevinden zich magazijnen van Kina-basten, welke daar onafgebroken worden aangebragt.

Gedurende den regentijd van 1847 hield de heer IVEDdecl ziclı met het onderzock van die groote magazijnen bezig, en toen dezc voorbij was gegaan, werden vervolgens de Provinciën Larecaja, Caupolican of Apolobamba onderzocht. De stad Sorata of Esquibel, gelegen op de westelijke lıelling der Andes en aan den voet van cenen der hoogste pieken, wordt te onregte gehoulen voor cene der voornaamste stapelplaatsen van de Kina. Zij is slechts de plaats waardoor de transito-handel van de producten der meer inwendig gelegen valleijen plaats vindt. Ilet was daarhenen, dat de hecl WeDdele zich hegaf over de hooge suecuwbergen van den Illaupo, 
alwaar de rivier 'lipoani, de hoofdstroom van Bolivië, haren oor' sprong ontleent. Langs de gevaarlijkste ravijuen, welke ziclı welligt ergens tor wercld bevinden, komt men tol het dorp Tipoani, eene zeer ongezonde plaats, alwaar alleen de zucht naar gervin (namelijk goud) den monsch kan nopen zich te vestigen. In alle deze streken vindt men Kina, maar gecne groote hoomen.

Ten einde de nog ondoordrongen streken te kunnen onderzocken, besloot de heer Wedpell de bosschen aan de Rio Mapiri te bezoeken, waarna hij, na vele togten, uitgeput van krachten en aangetast door de koorts, te Apolobamha aankwam. Dil land is meer heuvelachtig dan bergachlig en weinig boschrijk. De starl Apolobamba, bijna op eene kale vlakte gelegen, is het middelpunt van een der vroegst gec̈xploiteerle gedeelten van Bolivië en waar sedert lang geen Kina meer groeit. Om deze te vinden moest WEDDELL zich op cenen afstand van 8-10 dagrcizen van de bewoonde streken verwijdcren.

In Junij 1847 bezocht de heer Wendell de Provincie Carabaja, wclke in menig opzigt eene der meest bclangrijke is van golıcel Peru. De Cordillic̀res verdeelen zich daar in twee deelen, waarvan liet eene door hooge plateaux, het andere door lange en evenwijdig loopende valleijen wordt gevormd. Het is in die valleijen, dat, roor' 't grootste gedcclte, de Kina-baston worden ingezameld, welke tcgenwoordig uit Peru worden uitgevoerd. Bezoelien an de steden Sandia, Cruzero, Cuzco (de oude Incas-stad), de vallei Santa-Anna, Cocabambilla, schijnen de laatste punten van lict Kina-onderzoek van den heer IVedoelt geweest te zijn.

Wij hebluen bij de opgave van de door de heer Weonela bezochte plaatsen en de rightingen welke hij gevolgd liceft, ons mei 
opret langer bezigr gehouden, omdat hierdoor niet alleen de verbreiding der Kina boomen moet worden toegelicht, maar ook, omdat daardoor moel uitkomen, in hoeverre de Kina-streken iı Zuid-Amerika, na von Humbolnt, zijn onderzocht, en vermits aldus al de nasporingen op dit punt en van alle reizigers in ZuidAmerika, sedert de la Condanine in Loxa, Mutis in Nieuw-Grenada, Ruiz, Pavon, von Humboldt en Bonplanu in onderscheidene gedeelten van Amerika, eindelijk die van PoepPig om en hij Huanuco (waarvan wij hier niel opzetlelijk kunnen gewagen), een geheel maken mel die des Heeren Weddels, en ons inderdaad thans beter dan te voren de geographie der Ginchonen doen kennen. Het is te verwachten dat de onderzoekingen in Peru, nu onlangs door den ijverigen Hasskanl gedaan, onze kennis, in dil opzigt, nog meer volkomen zullen maken.

De Kinastreek heeft eene lengte van ongeveer 29 graden. Zij strekit zich uit van den $10^{\circ} \mathrm{N}$. Br. Lot den $19^{\circ} \mathrm{Z}$. Br. Zij vorml eene smalle strook, die min of meer bogtig is en die de rigting volgt van de groote Cordillières der Andes, te lieginnen van den 19 den zuidelijken parallel en meestal aan de oostelijke helling, waar zij op eene hoogte voorkomt, die volgens de breedte eenigzins afwisselt, maar die tusschen de 1,200 tot 5,270 meters lievat is. Het midden van de bogt, tevens het meest westelijke punt, dat het digtste bij de kusten is gelegen, bevindt ziclı, wat de holle zijde van de bogt hetreft, bij Loxa, op $82^{\circ}$ W. L. van Parijs. Het laagste punt grenst aan den $62^{\text {sten }}$ en het hougste verliest zich nabij den $71^{\text {stcn }}$ graad.

Het tableau van de vegctatie der Andes (1) geeft, in betreliking

(1) Essai sur la Créographie des plantes, accompagne diun lableatu physiquue 
tot de Kina-boomen, een overzigh van de loogte-punten, op welke de verschillende soorten voorkomen. De streek waar de Kina-boomen voorkomen, noemt von Hunbolot Région des Cinchones, en welke niel minder dan 2,200 meters uilgestrektheid in de hoogrte heeft, aanvangende bij de hoogle van 700 , en eindigende bij 2,900 meler's.

De geheele uitbreiding der Cinclionen of het zoogenaamde domein der Kina rekent WeDDell op ongeveer $4000 \square$ mijlen.

Tol nog toe heeft, na de la Condamne, niemand zoo opzettelijk en zoo uitvoerig alles wat tol de exploitatic van de Kina behoorl, nileengezel, als zulks in de laatste jaren door Dr. Wedpect gedaall is.

Hoezeer nu ook daarin wel een en ander te wenschen en te vragen overblijft, meenen wij evenwel aan den ijver en de zorgvuldigheid van dezen natuuronderzoeker hulde te moeten doen. Onze lezer's zullen (als wij ons niet bedriegen) ook deze bijzonderheden met belangstelling vernemen, indien zij die altlans, uil de werken van WebdeLL zelven niet mogten hebben leeren liennen.

De personen, die de Kina inzamelen, worden tot dil moeijelijk werk, van kinds af opgeleid. Men noemt ze Cascarilleros. Zonder ander kompas dan dal van een natuurlijk instincl, begeven zij zich in de onmetelijke bosschen, waar zij mot evenveel gerustlıeid ronddwalen, als hadden zij den horizon voor zich. Ongeoefenten evenwel raken verdoold en men vindt dan somwijlen lunne sporen nimmer terug.

des régions équinoxiales, par A $\mathrm{L}$. de Hunuozdr el $A$. Boxplaxd, rédigé par At. ne IIumoldt. Paris, 1805. 
De inzamelingstijıl is van Mci tol September. Dan volgt het regen-saisoen, 't welk ongeveer met onzen winter overecnkomt.

De Casearilleros zamelen de Kina celiter niet in voor eigen rekening. Zij doen dit onder opzigl van een' zoogenaamden Mayordomo, een vertrouwd persoon, die of door particuliere kooplieden, of door de eene of andere kleine compagnic wordt afgevaardigd en zieh met een gezelsehap Cascarilleros naar de bosschen begeeft. Hij houdt daarover het toezigt en draagt hovendicn zorg voor de ingezamelde schorsen, welke uit de onderselıeidene declen van de bosschen worden aangebragt.

Bij den aanvang van eene nieuve exploitatic in eene nog nict onderzochte streek, worden er diestros of practicos, gelijk men ze noemt, eene soort van kwartiermakers (gelijk wij zouden zeggen) vooruitgezonden. Het zijn de meest geocfende Cascarilleros, die de bossehen in alle rigtingen moeten doorkruisen, ten einde na te gaan, in hoeverre en in welke rigting het wenselielijk is, dezelve te exploiteren. Hecft men eene geschikte plaats gevonden, alsdan'wordt daar een soort van kamp ingerigt. Meı slaal er hutten en eenc soort van schuren op, de laatste om den Kina-voorraad te bewaren en tc besehutten, en men zaait in den omtrek Maïs en andere veldvruchten voor levensonderhoud. De ondervinding heeft geleerd, dat de inzameling te beter slaagt, naar gelang er meer voorraad van levensmiddelen in het kamp aauwezig is. De Cascarilleros trekt de bossehen in, voorzien van zijn' bijl en van eene soort van zak, die over zijnen schouder hangt, en verder van wat noodig is tot zijn cenvoudig nachtelijk leger. Hij is bij zijne nasporingen aan ecne menigte bezwaren en gevaren, dic zelfs zijn leven bedreigen, blootgesteld. De Kina- 
boomen vormen wel geene bosschen, maar komen toch hier en daar in kleinere groepen voor; anderen vindt men gelieel en al eenzaam staande tusschen andere boomen. De Cascarilleros erkent reeds aan de gesteldheid van de toppen der boomen, of aan de kleur of aan het geritsel der blaten, zoo als dit aan sommige boomsoorten karakteristiek is, die soorten, welke hij zockt, en het is opmerkelijk, hoe hij, reerls op eenen zeer grooten afstand, aan den bloei alleen, die zich aan de toppen der boomen vertoont, de soort die hij zoekt, kan erkennen. Somwijlen is hel ook alleen de schorslaag, die hem tot kenmerk dient. Anderzins zijn het de drooge en afgevallen bladen, die onder 't geboomte op den grond liggen.

Niet zelden komt hij, na lange inspanning, zouder eenige vrucht van zijnen moeitevollen togt te hebben medegebragt, terug, wanneer zijn voorraad voedsel verbruikt en hij tot die terugtogt wel genoodzaakt is. (1)

Men velt de boomen, ten einde ze te ontschorsen, nabij den wortel, zoo diep mogelijk in den grond, waar de bast tevens het dikste is. Van den gevallen boom neemt men 't eerst de buitenste laag, of het zoogenaamd opperhuidsvlies weg, door het te kloppen of te blekken met stukken hout of met den rug van den bijl. Daarna wordt het ontbloote deel van de schors met eenen borstel schoon gemaakt. Men snijdt vervolgens, door middel van messen,

(1) IIetgeen ons door WeDDELL is bekend geworden ten aanzien van deı arme cascarilleros, doet denken aan de bijna even ongelulikige kamferinzamelaars in de Battas-landen van Sumatra, waarvan wij de bijzonderheden donr Dr. Juvgnum hebben lecren kennen. Zie unijne Verhandeling over rien Kamferboom van Sumalra (Dryobalanops Camplinra Colebr.) volgens Dn. JuxGuuns's waarue. mingen, Lciden, 1851. 
strooken of plaatjes, in den vorm in welken men er die van wil afzonderen, en waarbij men zoo vecl mogelijk vermijdt om het lout mede weg te nemen. Men snijdt ook dikwerf den stam aan stukken, om dien te kunnen keeren en in alle rigtingen het schorsgedeelte weg te nemen. Zooveel als mogelijk is, tracht men aan die stukken eene lengle van 4-5 palmen en eene breedle van 8-10 duimen te geven. De schors van de takken wordt niet geklopt, en laarom komt die ook doorgaans, met de opperhuid of het buitenste vlies nog voorzien, in den handel voor.

Dat echter in de grootere stukken deze methode van behandeling niet altijd doorgaat, zulks bewijzen de stukken die men net de epidermis of opperhuid in den handel aantreft, en die de handelaars noemen: sine peridermide.

De wijze van droogen verschilt naar gelang dat de stukken van dunnere takken zijn genonten, als wanneer dit alleen door de zon geschiedt. De grootere stukken worden, om het krom trekken te verhinderen, geperst. Men legt ze, na eene eerstc blootstelling aan de zon, in vierkante stapels op elkander, zoo als men dit wel planken doet, en hierop plaatst men dan een of ander zwaar ligchaam. Hierna lloogt men ze op nieuw en zoo gaat men bij afwisseling voort. Goed droogen is altijl aan te bevelen, omdat door in deze stukken achtergebleven waterdeelen, de basten ligtelijk ecne soort van fermentatie ondergaan en te eenemale bederven.

De Kina, aldus ingezameld en bereid, moet dan nog uit de bosschen worden gebragt naar de stapelplaatseı. Hiertoc zijn vaak 15-20 dagen noodig, gedurende welke reize de cascarilleros zijnen zwaren last moet torschen langs eenen weg, dien hij slechts met mocite kon vervolgen, reeds toen hij nog nict met lict produlit 
helast was. Neemt men nu in aanmerkingr tot welken geringen prijs op de markten of de stapelplaatsen de Kina wordt betaald, dan kan men niet anders dan zich verwonderen, dat er menschen worden gevonden, die zich met ecnen arlıeid, die zóó slecht beloond wordt, willen afgeven. Van uit de kampen wordt de Kina in pakken op den rug des cascarilleros of op dicu van hunne muilezcls gedragen naar de steden, en aldaar in lederen zakken, welke men scroenen noemt, overgepakt en in den groothandel gebragt.

Dic serocnen wegen gewoonlijk 70-80 Ned. pd.

De uitvoer van de Kina uit Bolivië is, blijkens de opgave van WedDeLl, ook in zijne Ilistoire naturelle du Quinquina, zeer belangrijk. Hij kan echter in verre na niet voldoende zijn voor de behoefte. Wij mocten gelooven, dat die uitvoer niet in zijn geheel bekend is. Alleen de Companie van La Paz, aan welle de Boliviaansche Regering het monopolie van dit produkt had afgestaan, werd bevoegd verklaard tot een' jaarlijkschen uitvoer van 4000 quintalcn, of 40,000 Spaansche ponden, d. i. 400,000 kilogranmen Kina-bast. (1) Men legde haar ten laste dat zij deze hoeveelheid overschrijdt en er zijn, dien ten gevolge, reclames ontslaan.

Men neme nu eens aan, zegt $W_{\text {EDDELL }}$, dat er volstrekt gecnerlei beperking op den uitvoer bestond, tot welk cene mate zon die dan niet rijzen?

(1) Hel kivintaal gerekend tegen 100 Ned. ponden of kilogrammen.

Bij de Engelschen is liet livintaal of quintal een gewigt van $112 \mathrm{Eng}$. pul.

Het oude kivintaal van 100 Amsterdamsche pl. waaggewigt is $\Longrightarrow 49,409$ kilogr. - Het Fransche quintal $=48,951$. - Ilet Engelsche quintal $=$ 50,803. - IIet metrieke quintal $=100,000$ lilogram.

Ik volgde, bij het overbrengen vau de 4000 kwintalen, Waarvan Wennetus gewaigt, liet metrieke kwintial. 
Het is intusschen te betreuren, dat, omtrent den uitvoer uit verschillende havens van Peru vooral, en die van Nieurv-Grenada zoo velerlei legenstrijdige opgaven bestaan en bijna nergens juiste statistieke aanwijzingen gevonden worden betreffende dit gewigtig arlikel van handel.

Wednell b. v. verhaalt, dat de uitvoer van Kina uil Peru zóó enorm is, dat dit aan het fabelachtige grenst. Wij willen het gelooven, het moet zoo zijn. Van waar zou anders de enorme massa, die voor fabrieken van chinine noodig is, haren aanvoer hebben? Maar dezelfde Dr. Wedpell zegt ook, dat men thans uit de haven van Carthagena naauwelijks eenige arrobes (1) nitvoert, terwijl in 't begin dezer' eeuw, in 1806, die nitvoer tot het enorme cijfer van 1,200,000 ponden was geklommen. (2)

Het eerste, namelijk de groote uitvoer van Peru, is in regelregten strijd met een beweren van den Hr. Francis 'Castelnau, Fransch Consul te Bahia, in wiens boven reeds aangehaalde reize (5) wordt aangevoerd, dat de uitvoer van Kina uit Peru van weinig belang is, en wij moeten dit toestemmen, als wij de cijfers raadplegen betreffende de statistieke opgaven van den uilvoel uil Peru naar Europa en de Vercenigde Staten, gedurende de jaren 1858,1859 en 1840 , te welen :

$1858-5,579$ kwintalen 557,900 kil: waarde 164,570 piasters.

\begin{tabular}{|c|c|c|c|c|c|}
\hline $1859-866 \frac{1}{2}$ & 3 & 86,650 & $"$ & $"$ & 150,527 \\
\hline $1840-2,660$ & " & 266,000 & $n$ & $"$ & 117,999 \\
\hline
\end{tabular}

(1) Eenc arrobe is $=11 \frac{1}{2}$ lilogr. (volgens WeDD.)

(2) WendeLL L. i. pl. 13.

(3) Expédition dans les parties centrales de l’Amérique du. Sud. IV. p. 114.

(4) Het enorme verschil tusschen de jaren 1839 en 1840 zou hijna anulciding geven om rle juistheid der opgave te doen betwijfelen. 
Zeer opmerkelijk is let dat 'l'scuun (t. a. jl.) zegt, dat vroeger de Kína-bast een artikel van den groothandel voor Peru was, maar dat dit sedert lang in zijne warde is verminderd, vooral wegens de vele soorten, welke uit andere strcken worden aangevoerd. Onjuist moet het zijn, wanneer Tscuud beweert, lat, vooral wegens het gebruik der chinine, dic handel is verslapt, oundat namelijk ter bcreiding van dit loogzoulachtig beginsel niet zoo vecl Kina zou worlen gebezigd, als er vroeger in substantie in Europa werd gebruikt. Het niet doorgaan van zoodanige bewering is, dunkt mij, reeds uil dien hoofle tastbaar, vermits men, om dertig grammen zwavelzurc chinine tc maken, ongeveer een kilogramme calisaya-kina behoeft; hoe meer chinine men dus maakt, des te grooter mocl de behoefte aan meerderen uitvoer worden.

Gedurende den bcvrijdings-oorlog, zegt Tscirubi, onderging de Kina-handel den doodslag, terwijl er vele jaren verliepen, in welke uit Peru geen enkele centenaar Kina werd uitgevoerd. Gecn wonder, bij revolutiën of oorlog waagt niemand zijne kapitalen lot exploitatiön of industriële ondernemingen.

Wat de inzameling en behandeling betreft, zijn, voor liet overige, de berigten van Wedpell en Tsciudr eensluidende, en hierbij hehocven wij dus nict stil tc staan. Maar, zecr belangrijk is het, wat Pocprig mededcelt, dat de versclie groene hast mel liet beste gevolg wordt tocgediend. (1)

Vor van allc bewoonde oorden waar men geneeskundige lutp kon inroepen, ziclı verwijderd bevindende, leed Posprıg aan eene lıcvige andercndaagsclıe koorts. Hij bezigde den versclı van de

(1) Reise in Chili, Peru, und den Amazonen-Strïms. n. s. w. 
boomstammen afgenomen, groencn bast met het gelukkigste gevolg en zulks tot dric malen toe op verschillende tijulen, en liad alzoo liet voorregt, om in ruime mate de werking van een zoo uitnemend geneesmiddel als de Kina in eenen zuiveren en gelıeel onvermengden of onveranderden toestand te ondervinden. Deze omstandigheid geeft althans een bewijs, dat de bast in den groenen en verschen staat reeds het belangrijke loogzoutachtig beginsel bevat, waarom wij dit geneesmiddel te regt zoo hoogschatlen.

Er blijven, na de hoogst belangrijke mededeelingen van WeddecL, eenige vragen en wenschen over, waarop later nog moel worden teruggekomen.

Wij zouden b. v., ook in ' $\mathrm{L}$ belang der' kultuur van de Krinaboomen, gewenscht hebben dat de heer WeDdect hadde kunnen doen kennen, in welke gronden de Kina-boomen groeijen, opdat men bij zijne terugkomst die gronden aan een sclieikundig onderzoek had kunnen onderwerpen; dat hij had toegelicht hoe hoog de ver'schillende boomsoorten, van welke de basten in den lıandel voorkomen, gemiddeld worden; - hoe de verdere afmelingen zijn van den stam; - loe oud een boom moet wezen, alvorens hij het koortsdrijvende beginsel voldoende bevat en tol Kina-inzameling kan dienen; — of men de hoomen altija moet vellen; dan wel of men ze kan schillen zonder ze te vellen (1); wat de hoeveelheid ponden hina is, die een hoom van zekeren leeflijd, loogte en dikte van den stam gemidleld lian opleveren.

(1) Ontrent dit punt lezen wij bij Posupig het volgende:

"Bei einirger Vorsicht von Seiten der Cascarilleros wünden die verschiedenen "Cinchona-bätume nic ausgerottet werden. Mat hat blos die Vorsichı zu beob"achten den Stamm möglichst nahe an den Wurzel abzuhnuen, um des Nach- 
Wij zoeken te vergecls in de geschriften, welke tot dus verre over dit onderwerp zijn verschenen en ook in lict werk van Dr. Wennelu, naar de oplossing van zulke belangrijke vrageu, waaraan wij, nu vooral, bij de overbrengst van de Kina naar het eiland Java, behocfte gevoelen. Slechts verspreide en als 't ware toevallige data moeten ons bij benadering tot andere, waaromtrent ivij nergens bepaalde aanteckening vinden, doen besluiten.

Het onderwerp der Kina, op zijn tegenwoordig standpunt, is een der mocijelijkste in lıet gebied der natuurkundige wetenschappen. Het is daarbij van ecnen zeer grooten omvang; het grijpt aan de eene zijde in de natuurlijke geschiedenis, de geneeskunst en de sclieikunde, aan de andere in het gelied van den handel van de meeste zeevarende en handeldrijvende volken.

De omstandigheid, dat men al vroeg zoo vele tegenstrijdigheden omtrent het nut en de aanwending van dezen bast vindt aangereekend, moest (het werd boven reculs aangemerkt) al dadelịjli leiden tot het vermoeden, dat men Kina-basten van ondersclıciden kwaliteiten had aangevoerd, en dus evenzecr tot de meening dat Zuid-Amerika basten van verschillend gehalte en denglzaamleid oplevert. De loop der tijden heeft dit te eenemale bercsligl. De basten, op onderscheidene tijdstippen van de hina-gुeschichlenis, en uit verschillende landen van Amerika aangevocril, rerschillen in hoclanighcid derwijze, dat men, in lateren lijd, nict liceft

\footnotetext{
"waehsens aus derselben gewis seyn zü diürlen. I" den milderen Gegenden, wie "um Cuchero, erfolgt dieses so schnell, das man schon nach sechs Jahiren "dic jungen Stammen von Nenen fällen lian; in der Lislten der Puna benach"barten Region der Cejawälder, wo die allerwirksamsten Cinehonen wachsen. "sind gegen \%wanzig Jahren erforderlicht." PoEprus lieize 1. a. pl. II. 222.
} 
geaarzeld, om ze van verschillende soorten van planten af te leiden, waartoe men echter vaak zonder genoegzame en op onzekere gronden besloot.

Wat de geschiedenis dienaangaande heeft geboekstaafd, is luttel en onzeker. Dat er in den loop der tijden Kina is aangevoerd van Loxa, uit Peru, van Bolivië en van Nieuw-Grenada, dil staat vast. Maar welke soorten waren het, en op welke tijden is haar invoer geschied. Hieromtrent kunnen wij ons slechts in gissingen verdiepen of moeten ons met onzekere opgaven te vrede stellen.

Een Hamburger droogerijen-handelaal Heinrici von Bebgen (1), leverde een geschrift, hetwelk voor den tijd waarin hij schreef, en in meer dan een opzigt nog tegenwoordig verdienste heeft.

Von Bergen heeft de volgende Kinasoorten onderscheiden:

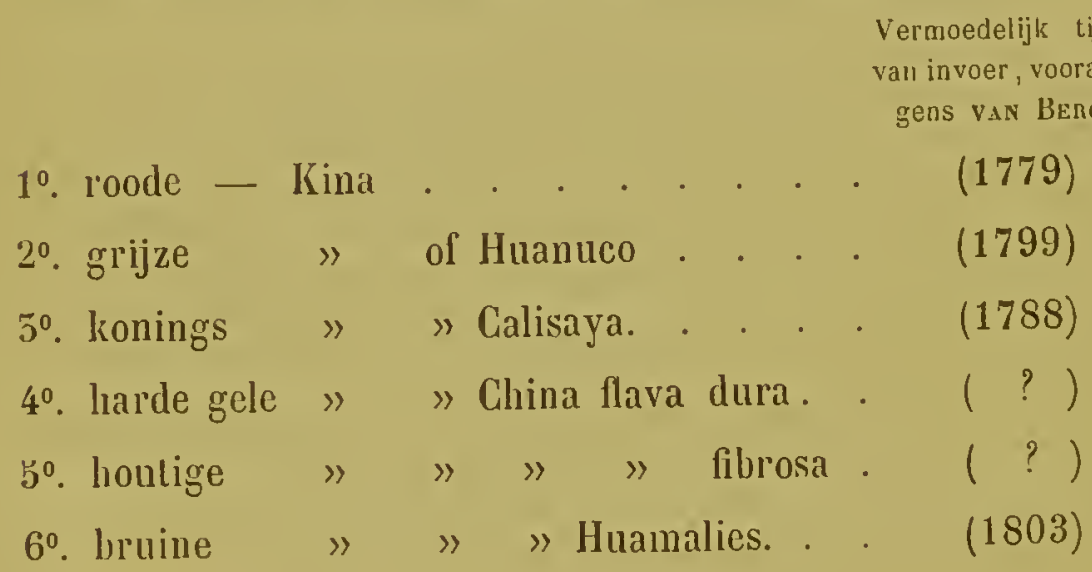

(1) Monographic der Ghina. Hamburg 1826, mil Kupfertafeln und Tahellen. VriJdak ZiJnen, de Kina-basten van den Ilandel, 1835.

Jonathas Peneind, The elements of the materia medica and therapeutics. III. Edition. vol. II. part. II. London 1853. p. 1605, Het laalstgenoemule geschrift beval veel, van hetgeen tot dit onderwerp behoort, bijecngebragt.

Dr. C. А. J. А. Oudemass, Aantcckeningen op de Pharmacopoca Necrlandica, 2de Al1. liollerilant, 1855. 
$7^{0}$. Kroon - Kina of China Loxa $(1)$ het ende der Xvil Eeuw?

$8^{\circ}$. bleeke of ten-Kina » " Jaen.

$(180 \tilde{3})$

Er zijn sedert von Bergen's geschrift, zoo velerlei soorten en verscheidenheden van Kina-basten in den liandel gekomen of onderscheiden en beschreven geworden, dal men bij de bovengenoemde eene geheele nieuwe reeks zou kunnen voegen.

De afbeeldingen van von BerGes's soorten van Kina-basten zijn gelijk aan het heste, wat men later over dit onderwerp heeft in het licht gegeven. $Z$ ij maken welligt de grootste verdienste van zijn werk uit. Zij worden niet overtroffen door die, welke DElondre en Boughardat in hel vorige jaar te Parijs hebhen in hel licht gegeven (2).

De beschrijvingen van vos Bergen zijn naauwleurig, maar de kenmerken waarop hij zijne liarakteristick heeft gegr'ond, kan men thans niet meer in allen deele essentiële kenmerlien noemen, ondat zij niet zoo zeer het wezen, maar slechts uiterlijke karakters wedergeven. Die karakters nu werden door hem ontleend aan de vormen der Kina-slukken, hunne uit- en inwendige gesteldheid (althans wat de oppervlakte betreft) het meer of mindere verschil van de doorbreuk, den geur, de kleur' en den smaak.

De karakteristiek van von Bergen’s Kina-soorten lieeft intusschen nog eene andere rigling, - en men zou onregt doen door dit uit het oog te verliezen, - maar welke toch in de praktijk nict geheel en al zonder bedenking en bezwaar schijnt te wezen. Het zijn de ken-

(1) Dit is vermoedelijk de ecrste als lamdels-arliliel ingevocrde kina van deze soort. Volgeus vroegere auteurs toch, is liet jaar van iuvoer 1640 of 1632.

(2) Quinologic. Des quinquinas el des questions qui dans l'ilat présent de la science el du commerce s'y ratlâchent. Jaris, 1854. 
merken, welke te ontleenen zijn aan de veranderingen welke in aftreksels of afkooksels van de hina worlen te weeg gelıragl, door sommige sclıeikundige hereidsels, als : galnoten-tinctuur, zoutzuur ijzerverzuursel, sulphas ferri, visehlijm enz.

Op grond van eigene ondervinding zou ik durven verklaren, dat, indien de opgegeven eigensehappen al mogen doorgaan, - die kenmerken voor de praktijk en alzoo voor de herkenning van soorten van basten, voor het algemeen, moeijelijk aan te wenden zijn, en dii om redenen hieronder te vermelden.

Toen in 1842, hij Koninklijk Besluil van 21 Auguslus, ㄲ․ 26 werd bepaald, dal el eene hierziening van de I'harmaeopoea Belgica zou plaats hebben, was met eenige andere deskundigen (1) die taak mede opgedragen aan den steller van deze aanteekeningen en den sedert eenige jaren overleden Amsterdamsehen sehei- eu artsenij-bereidkundige A. J. D'ArLty. In de werkplaats van dien bekwamen man, zijn in een volgend jaar door hem en mij gezamenlijk een aantal reaetiën herhaald en de uilkomsten met die, welke vox Bergen heeft opgegeven, voor een deel niel in overeenstemming bevonden. De tahellen, waarin de uilkomsten van die proeven vervat zijn, zouden hier misplaatst wezen; maar indien dit noodig mogt wezen, kunnen zij worden geleverd.

Ik kan niet aannemen, dat een zoo hekwaam Artsenijbereider als de heer D'Altur, die gedurende eene lange reeks van jaren als schei- en artsenijhereidkundige aan het hoofl heeft gestaan van eene der roornanmste fabrieken in ons land, en die zoo zeer

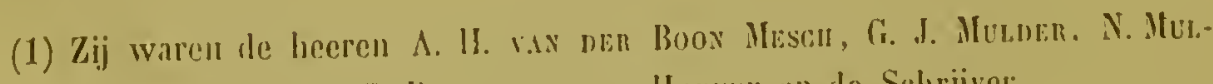

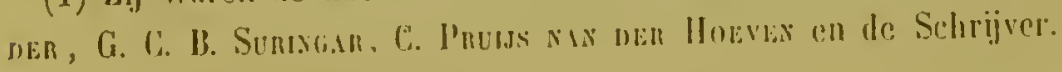


liet algemeen vertrouwen heeft mogen genieten, inzonderlieid ook van al zijne medeleden der evengenoemde Staats-Commissie, zulke eenvoudige en gemakkelijke reactie-proeven niet met genoegzanse kennis en voorzorg zou heblen genomen en ik moet dus komen tot dit alternatief, dat òl de door vor Bengen opgegeven reactiën niet in alle soorten of verscheidenleden doorgaan als kenmerken van de Kina-soorten, ôf dat de uiterlijke kenmerken van soorten en sorteringen van basten eenigermate onzeker zijn, zoodat zells mannen, die grondige kennis en eene veeljarige ondervinding in liun vak bezitten en die ook in de behandeling en herkenning der Kiula-basten eenigen roem heblen verworven, in dat sortereı kunnen dwalen. Is dit laatste waar, hoe zal het dan wel gesteld zijn met hen, die niet in de gelegenheid waren eene zoo ruime ondervinding en kennis op te doen.

De melhode van von Bergen, om de Kina naar uiterlijke kenmerken te diagnosticeren, die langen tijd de algemeene geweest is, werd ook door de schrijvers van de herziene Plarmacopoea, die sedert onder den titel van Pharmacopoea Neerlandica is uitgegeveu en in 1849 kracht van wet verkreeg, gevolgd. Men lieeft sedert eenen anderen weg ingeslagen, die van de zijde eener strenge wetenscliap, goede uitkomsten schijnt te beloven en reeds gedeeltelijk heeft geleverd. Het was de aanwending van den mikroskoop tot lret leeren kennen van het innerlijke maaksel der basten, waarhij de waarueming met let bloote oog of met gewone vergroolglazen te kort schiet; uit welk microscopisclı onderzoek de Heer $W_{\text {EDDELL }}$ heeft afgeleid, dat er eene niet te miskennen overeenkomst bestaat tusschen de kenmerken van de structuur en die wellie aan de sclreikundige zanenstelling der hasten worden ontleent. 
De heer WEDbets heeft langs dien weg eene andere rigting aan heL Kina-onderzoek gegeven, dan waarin men tot hiertoe verkeerd heeft. Komt men nu eenmaal na een naauwkeurig eı vergelijkend onderzoek van de structuur der verschillende Kitla-hasten tot liet vinden van differentieële karakters der Kina-soorten, dan voorzeker zal de heer Wedpect eene verdienste te meer hebben. Wij willen het beste van zijne pogingen hopen, zonder de resultaten vooruit te loopen.

Maar, het is voor eene riglige orde in deze voordragt noodig, dat wij voor eene wijl ons van het natuurkundig gebied op dat der geneeskunde begeven, om later op het eerste, mel des te beter gevolg, terug te komen.

Zoo verre zich het Plantenrijk uitstrekt, van het noorden tot het zuiden, van de oppervlakte der aarde tot de toppen der bergen, is dit den Mensch en al het geschapene ten zegen. Geen nederig grashalmpje mist het doel van zijn aanzijn in de groote huishouding der natuur. Menschen en dieren kunnen slechts leven dáár, waar de oppervlakte der aarde met planten bedekt is. De noordelijkste en zuidelijkste volken in dit opzigt kariger bedeeld, vinden niettemin voorziening in hunne behoeften, bij gezonden en zieken loestand, in lretgeen de bodem waarop zij wonen, oplevert. Maar binnen de keerkringen, dáár, waar de zon hare stralen bijna loodregt op de aarde laat vallen, - waar warmte, licht en vochtigheid vereenigd en in hoogen graad aanwezig zijn; - daar is het aardrijk als met eenen prachtigen gordel van de heerlijkste en nulligste gewassen omgeven en biedt dit den mensch op vele plaatsen, zelfs zonder zijn loedoen, voor zijn onderhoud eenen overvloed aaı, die alle voorstelling overtreft. 
Het was voorzeker geen louter toeval, dat onder dit millivenental van de voortbrengselen van het groeijend natuur-rijk in ds: keerkrings-landen van Amerika, eenen boom deed ontdekken, die als eene der grootste zegreningen, door de Voorzienigheid aan het menschdom geschonken, is te beschouwen, en wiens waarde niet kan worden geëvenaard door al de edele metalen en kostbare gesteenten, die de schoot der aarde bevat. Gaven de mijnen van Per'u aan Spanje weleer ongehoorde schatten, die echter als Spanjes toenmalige grootheid zijn verdwenen; - in den koortsbast, dien de Spanjaarden het eerst dedeu kennen, verkreeg het Menschdom een Groddelijk geschenk en gelijk wij hopen, althans wenschen, een' blijvenden zegen. Al de schatten der aarde zijn niet in staat, bij dreigend gevaar, één menschen-leven te behouden, maar de Kina redt van een gewis verderf en trekt den lijdende, als mel geweld, uit de armen des doods terug.

Welk ook het verschil van gevoelen van geneeskundigen, omtrent het heirleger van plantaardige middelen ter genezing aangeprezen, zijn moge, - in dit opzigt zullen wel de meeste, zoo niet alle artsen overeenstemmen, dat daaronder aan de Kina de allereerste plaats toekom en dat de ondervinding van ruim twee honderd jaren heeft bewezen, dat de Kina onmisbaar en in hare eigenaardige werking op het ligchaam door geen der bekende voortbrengselen der aarde te vervangen is.

Dat dit werkelijk zoo is, moge, voor niet-genceskundige lezers, door liet volgende worden toegelicht.

IIct menschelijk ligchaam is vaak onderhevig aan ziekelijke aandoeningen, die ecuen geheel periodicken vorm hebben, dat is, dis zich op regelumalige lijgen voordoen. of zich na zockere 
Lusschempoozingen vertoonen en din weder verdwijnen. In die lussclentijden is de lijder dikwijls volkomen wel; somwijlen bijitl echlter eene of andere ziekelijke gesteldheid over, die van hei periodick verschijnsel de oorzaak of het gevolg is. Aan den toestand van wèlgevoelen maakt de terugkeer van den aanval plotseling cen cinde. Die periodieke verschijnselen zijn in hunnen aard of wezen duister en in liunne oorzaken onbekend. Van hunne hevigheid, hunnen korteren of langeren duur, van de verschijnselen die er mede gepaard gaan, van de organen, welke daarhij vooral worden betrokken, van den individuëlen toestand des lijders, hangt de meerdere of mindere mate van het gevaar af, dat laarbij is te duchten. De tusschenpoozende (intermitterende) koortsen bchooren tol die periodieke ziekten. Onder deze zijn er vaak van eene zoo kwaalaardige natuur en zoo verraderlijken vorm, dat zij bij den lweeden aanval dooden, indien de arts het gevaar niel inziende, niel ter juister tijd de Kina of hare bij uitnemendheid koortsverdrijvende bereidsels aanwendt. De zouten van chinine zijn dan het eenige zckere en veilige anti-periodieke geneesmiddel, - hij haar gemis volgt vaak een gewisse dood. De ondervinding van alle artsen heeft dit gestaafd (1), en zonder van de schier dagelijksche ondervinding te gewagen, vooral in het jaar 1826, tijlens de epidemie, die toenmaals inzonderheid de noordelijke gedeelten van ons vaderland heeft getcisterd, genoegzaan bevestigd, van welk cen heilzamen invloed de Kina is als koortsverdrijvend geneesmiddel. (2)

De Kina, sedert hare ontdekking en invoer, met eenige uit-

(1) Tokт, iherapeutice specialis ad febres perniciosas. Francofurti ct Lipsiac. 1754.

(2) Nen zis de geseluriften teze epidemic betreflente. uitgegeven donr 
zonderingen, op haren regrten prijs gesteld, steeg vooral in de hoogste waarde, toen in liet jaar 1820 twee Fransche scleeikundigen outdckten, dat er in de Kina-basten een beginsel voorlianden is, waarin het koortsverdrijvend vermogen als het ware bij voorkeur zijuen zetcl heeft en dus in den hoogsten graad is geconcentrecrd. Het waren de heeren Pescetien en Caventou te Parijs, die uil de Kina-basten de zoogenaamle Kina-alcaloïden hereid heblen en aan wie de eere toekomt van de schoonste ontdekking te hebben gedaan, die de nieuwere scheikunde aan de praktische geneeskunst heeft bewezen. (1)

De Fransche regering schonk aan die bekwame mannen daarvoor een belooning van 10,000 francs, die welligt nog aanzienlijker zou geweest zijn, indicn men toenmaals reeds in zijn' geheelen omvang en met zekerheid had kunnen vooruitzien, van welk eene onschatbare waarde die ontdekking voor het menschdom zou worden.

De chinine en cinchonine, de eerste als koortsverdrijvend middel bij uitnemenheid hoog geschat, de laatste misschien niel genoegzaam als zoodanig gewaardeerd en welligt te onregte, reeds kort na hare ontdckking, bijna geheel ter zijde gesteld, maken wel cen zeer vooruaam bestanddeel uit van de Kina, maar stellen toch, wat men zou kunnen nocmen, hare quintescence niet daar, zoodanig dat zij al wat de Kina geneeshrachtigs inhoudt, als let ware in cenen geconcentrecrden toestand zouden bevatten. Het tegendeel is waar. De scheikundige wetenschap lecrde ons in de

E. J. Tuomassen a Tuuessink. (Algemeen overzigt der zickite, wellie in 1826 epidemisch te Groningen geheurselıt heeft.)

Jelat Barga (Verhandeling over de epidemiselıe zielite van 1820 in de noordelijke Provinciën der Nederlanden, 1328) enz.

(1) Annales de Chimie et de pliysique. V. 15. p. 289. 337. 
onderscheidene soorten van Kina-basten meerdere andere bestand. deelen kennen, om welke wij die ook behooren hoog te schatten; en de geneeskunst lecrt dagelijks van welk eene onwaardecrbare waarde ook die soorten van basten zijn, in welke een van beide cerstgenoemde beginsels in kleinere hoeveelheid of bijna in 't geheel niet aanwezig is. Maar als de meest waardige en de meest koortsdrijvende, worden niet te min die basten aanbevolen, die deze stoffen, maar vooral de chinine, in grootere hoeveelheid bevatten.

De Calisaya- of Konings-Kina staat in dit opzigt op den hoogsten trap en zij heeft als zoodanig van alle basten de grootste waarle: het chinine-gehalte is toch steeds de maatstaf van de waarderingr ler soorten, die de handel aanbiedt.

Dit hebben de natuur- en geneeskundigen, dic zich met dit onderzoek op eene zuiver weteuschappelijke wijze hebben afgegeven, allezins bevestigd. Dit onderzoek gaf, als van zell, aanleiding tot eene classificatie van basten, op een ander beginsel dan dat , van de kenmerken van de kleur (1) of den geographischen oorsprong, dat is, den naam van het land, waar de inzameling verondersteld was te hebben plaats gehad. Hoe wisselvallig b. v. de kleur is, kan zelfs iemand van weinig ondervinding in het Kinavak weten; en dat bijna al de soorten van Zuid-Amerika zich van den $10^{\text {den }}$ graad N. Br. tot den $19^{\text {den }}$ graad Z. Br. uitbreideı, dit is met zekerheid uitgemaakt. De onderscheidene soorten van Ginchonen zijn aan geen gedeclte van de Kina-streek uitsluitend ge-

(1) Bij de redactic der Nederl. Pharmacopoea is geene verdeeling van linabasten naar de kleur, gelijk te onregte heweend is, gevolgu. Dat men moest spreken van bruine, roode en gele bas ten, omdal leze zoo heeten, sprak van zelf, en de Kouings-Kin zou din geheel huiten de klassificatic gevallen ziju. 
bonden: een verschijusel dat welligt in verband staat met de eigenaardige gesteldleid der zeer kleine, mot vliezige uitbreidsels voorziene en derlaalve door den wind gemakkclijk naar zeer verre afstanden verstuivende zaden, waardoor deze in verwijderde streken, vaak op lionderden mijlen afstands, kunnen kiemen en ziclı tot boomen ontwikkelen.

Men zocht nu de onderscheidingskarakters in de al of niet aanwezigheid en hoeveelheid der alcaloïden, dat is, de chinine en cinchonine. Hierop werd tevens eene verdeeling der basten gegrond, en dit wel inzonderheid naar aauleiding der vergelijkende onderzoekingen van Prof. Pfaff te Kiel (1), welke leerden, dat er basten zijn, die beide en die een van beide, of geen van beide alcaloïden bevatten.

De lieer WeDDELL heeft, in zijn meer aangehaald geschrift, in meer dan een opzigt, eenen nieuwen en beteren weg in de historie der Kina-basten betreden. Hij zet geene namen van basten voorop, waardoor men in twee eeuwen zoo weinig vorderde en slechts staan bleef bij het standpunt van de eerste kindsclllieid der warenkunde; - neen, hij trachtte, zoo veel in zijn vermogen was, in Zuid-Amerika de soorten van boomen te onderscheiden en te bepalen, door welke soorten van Cinchona de bastsoorten, zoo als die in den handel zijn onderscheiden, worden opgeleverd. Onderscheidene omstandigheden lieblen te weeg gebragl, dat WeDdell daarin beter kon slagen dan de meeste

(1) Abhandlung von Herm Prof. PFafy, in von Bergen's Monograplie der China, p. 333. 'Tromml. Jouru. de Pharm. Bel. XXV, s. 3. Schweigg. Journ. Bd. $X$, s. 259. - Zie het meer aangehaalde werkje vau den Ileer VIndos Zisses p. 36 en volg. 
zijner voorgangers op dit nitgestrekt gebied. De kemnis van hetgeen deze ladden verrigl, stond hem natuurlijk ten dienste, en hij lion die kennis gedurende een langdurig verblijf en op zijne in bijna alle riglingen op let gebied van Bolivië en Peru volbragte logten, ter toetse te brengen. De uitwendige karakterisliek, het innerlijke maaksel en de seheikundige zamenstelling der basten moesten de kina-geschiedenis, zoo als IVEDDELL zulks heeft voorgedragen, volkomen maken. Weddect is dus thans bovenal onze autoriteit in het gewigtige onderwerp, wat hij zoo uitmuntend heeft hehandeld, en een groot deel van de vroegere autoriteiten moel, na WeDDELL, gerekend worden te zijn vervallen.

Alvorens dil eerste gedeelte van onze taak te eindigen, zij liel mij vergund nog voor eenige hoofdresultaten van WeddecL's reize, in verband net het tweede gedeelte van dit opstel, den invoer namelijk der Kina-boomen op Java, de aandacht des geëerden Lezers beseheidenlijk in te roepen.

WEDDELL besehrijft 21 soorten, allen van het eigenlijke geslacht Cinchona.

Onder deze soorten verdient onze bijzondere aandacht, ook wegens hare overbrengst naar Java

De Cinchona Calisaya WedD. Deze bewoont Bolivië en Zuidelijk Peru. Het is een lonoge boom met een' regten stam, niet zelden het dubbele van den omvang van het midden eens volwassen mans liebbende. De kroon dezes booms is zeer bladrijk, en overtreft bijna die van al de boomen van het woud door hare sterlic ontwikkeling. Deze soort komt voor in de alhelling van het gebergte op 1500-1800 meters, in de bossehen van de heetste valleijen van 
Bolivië en zuidelijk Peru op $15^{\circ}-16^{\circ} 50^{\prime} \mathrm{Z}$. Br. en $68^{\circ} \cdot 72^{\circ} \mathrm{W}$. Lengte, bepaaldelijk derhalve in de Boliviaansche provinciën Enquisivi, Yungos, Larecaja, Caupolican en in de provincie Garabaya van Pertu. De bloeitijd is April en Mei. Bij de Indianen en de Spanjaarden wordt de bast dezes booms onverschillig met den naam cascarilla, calisaya of culisaya aangeduid.

Deze soort levert den kostbaarsten van alle basten op, welke men in de geneeskunde bezigt, die in den liandel onder den naam van Calisaya, Quinquina Calisaya of Konings-Kina bekend is en waarvan de botanische oorsprong door WEDDELL liet eerst wetenscliappelijk is aangetoond.

Het kan uict liggen in liet plan van deze anteekeningen om de geheele historie van de kinabasten te behandelen ; alleenlijk willen wij nog kortelijk wijzen op de nasporingen door de heeren Delondre en Bouchardat in een scheikundig opzigt gedaan.

De heer Delondre heeft met Weddell, gedeeltelijk althans, de Kina-streken van Bolivië doorkruisd, en is in de kennis der basten zeker mede een man van gezag. Hij beproefde in 1828 de exploitatie in het groot in Bolivië, maar vermogt niet te slagen.

Hij maakte in 1858 zijne bevindingen aaugaande de Calisaya bekend, benevens de ontledingen met HénRY gedaall, waaruit blijkt:

1.. dat de bladen en vrucliten niet dezelfde loogzoutachtige beginsels bevatten als de basten van takiken en stammen;

2. dat de scliorsen van de wortels die loogzoutachtige stoffen ook bevatten, hoewel in mindere hoeveellieid;

$3^{\circ}$. dat de sappen, door iusuijding uit den stam verkregen, dezelfde bestanddeelen bevatten, als de nittreksels van de basten ill water. (1)

Merken wij op, dat vooral dit laatsle van veel belang is.

(1) Degontire cil Bovchardat, p. 24. 
Niet alleen toch zou dit aanteiding kunnen geven dat de aldus te extraheren stoffen, in plaats van de basten zouden kunnen worden overgezonden, uit de landen waar de Kina groeit of waar men ze nu reeds kweekt; maar liet zou welligt aanleiding kunnen geven tot het beliouden van boomen, wier stammen men anders, door ze om te houên of te schillen, verliest. Op Java zal men al spoedig de proef kunnen nemen, in hoeverre het door Deconde aangegeven denkbeeld van toepassing zij, zonder het leven van den boom in gevaar te brengen. De scheikundige ontleding van het uitvlocijende sap, zou moeten uitmaken, welke de verhouding van de alcaloiden zij en in hoever're de geheele zaak van toepassing zou zijn te achten.

Delondre zegt dat deze Kina in seroenen van $70-75$ kilogrammen meestal uit de haven van Arica, somwijlen uit dien van Colya wordt uitgevoerd. Deconbre verneldt de belangrijke omstandiglıeid, dat, in 1837, de eigenaars van de Kina in Peru, Bolivië en Chili al humnen voorraad met dien van eenen groothandelaar Don Francisco de Los Heros vereenigden, aan wien zij de vrijheid lieten om met de furma Pelletier, Delondre en Levaillant een contrakt aan te gaan, wegens de levering van 12,000 seroenen Kina, die gemiddeld 32 grammen en 25 centigrammen zwavelzure chinine (1) per

(1) In den kinabast zijn de chininc en de cinchonine rerbonden met eene eigene soort van zuur, het kina-zuur. Bij de bcreiding van chininc wordt dit zuur van de twee eerstgcnoemde stoflen afgescheiden, en door bijroeging ran zwavelzuur bij het vocht, hetwelk de chinine alsdan in oplossing berat, ontstaat daarin de zwavelzure chinine. Tot nadcre toeliehting van het bovenstaande dicne het volgende.

Nadat door de ontdekking van Derosae en Sertürner van twec plantenbascs in het opium (de narcotine en de morphine) de aandacht der scheikundigen op deze stoffen gevestigd was, ontdekten, gelijk boven vermeld is, de hecren Pelletrer en Caventou in 1820 de chimine of quinine. Hierna legden zij zich spoedig toc op de fabriekmatige bereiding, nict ran de basis (de chi- 
liilogr. moesten opleveren, hebbende de geleverde massa aan dit vereischte werkelijk voldaan. IIij voegt er bij, dat er welligt nimmer grooter koop is gesloten, en wij voeren dit feit hier ter plaatse aan, als cen bewijs van den enormen uitvoer, die in vorige jaren, uit die landen heeft plaats gehad.

Men onderscheidt de Calisaya-Kina als volgt:

$$
\begin{array}{ll}
\text { Zwavelz. } & \text { Zwavelz. } \\
\text { ehinin. } & \text { einchonin. }
\end{array}
$$

a. Platte stukken, welke opleveren 30-32 gr. 3-8 gr.

b. Pijp- of opgerolde stukken, welke opleveren

$$
15-20 \text { " } 8-10 \text { " }
$$

Het spreekt wel van zelve, dat men zulk eene opbrengst alleen van echte calisaya-kina bekomt.

De toenemende schaarschheid van deze Kina-soort en de noodzakelijk daaruit voor'gevloeide hoogere prijs der echte Calisaya hebben te weeg gebragt, dat de fabrikanten van zwa* velzure chinine in den laatsten tijd hunne toevlugt hebben genomen tot andere soorten, die wel goedkooper zijn, maar minder opleveren.

Ook nieuw Grenada lever' eene Calisaya op van Santa Fé de Bogota, die in alcaloide-gehlalte aan de Calisaya van Bolivië zeer nabij komt, want zij bevat 30.52 grammen zwavel-

nine zelve), maar van het zwavelzure zout, den sulphas chinicus, sulphate de chinine. Dit zout, dat weldra ook in andere landen fabriekmatig bereid werd, kwam spoedig zoo algemeen in gebruik, dat het regel werd, om bij de bepaling van de handelswanrde ecner kina-soort, te ouderzocken, hoeveel van dat kostbare kina-zout daaruit kon verkregen worden. Aangezien dus het gebruik van den sulphas chinieus in de geneeskunde algemeen is, terwijl de zuivere basis bijua nooit gebruikt wordt en in dat geval altijd nit den sulphas ehinieus wordt daargesteld, die in het groot fabriekmatig bereid wordt, zoo is dit de reden, warom versehillende sehrijvers over kina nooit van de zuivere basis, maar altijd van de zwavelzure elinine, den sulphas eliniens, spreken. 
zure chinine en 5-4 grammen zwavelzure cinchonine op elk kilogram.

Aan dit gelıalte van zwavelzure chinine konten lict naaste bij de hoogroode lina (Quinquina rouge vi/) met $20-25$ grammen zwavelzure-chinine en 10-12 grammen zwavelzure cinchonine, alsmede de quirquina pitayo van Nieuw Grenada mel gelijke loeveelheid. (1) Maar zeer sterk wijken daarvan al de Loxa- en de Huanuco-kina, gelijk uit het volgende kan blijken.

Eerslgenoemde, bij de Franschen bekend als Quinquina gris fin de Loxa, terwijl de zwartgrijze kleur vermoedelijk aanleiding was dat de Indianen haar Cascarilla negrilla noemden, wordt in seroenen van 50-60 kilogrammen uitgevoerd uit de haven van Guayaquil en somwijlen uit die van Payta. Men vindt haar, gelijk hierboven vermeld is, in de bosschen van Loxa. Delonde verkreeg daaruit 2 grammen zwavelzure chinine en 10 grammen zwavelzure cinchonine per kilogr. (2)

De Quinquina gris fin condaminea wordt van de laatslgenocmde quinquina gris fur de Loxa, door de Franschen onderscheiden. Zij bestaat uit kleine, fijne, gerolde pijpjes van 3 strepen dikte, is grijs-zilverkleurig van buiten, in alle rigtingen fijn gespleten; de spleten op de breuk hebben een harsigen glans met fijne vezels. Ilet produlit der ontleding op het gelıalte der alcaloideën was 8 grammen zwavelzure chinine en 6 grammen zwavelzure cinchonine. Derondre is genegen uit dit gehalte van die kleine takjes te bestuiten tot eenen grooteren rijjidom in dil opzigt van den stam, waardoor, volgens dien scheikundige, deze kina-soort tot de Calisaya zeer zou moeten naderen.

Deze bast nu is de Quinquina gris fin de Lima, aldus ooli

(1) Deiondue ch Boucinanat, p. 34, pl. 12.

(2) Dezclfden, 1. а. pl. p. 30. 
genoemd, omdat men haar, gelijk Detonbre beweerd heeft, sedert hare eersle ontdekling, van Lima naar Spanje zou hebben gezonden. Von Ilumbolot en Bonpland noemden hare moederplant Cinchona Condaminea, naar den beroemden sterrekundige, die deze plantsoort 't eerst liad doen kennen. Deze Kina-soort wordt mede langs Guayaquil uitgevoerd in seroenen en somwijlen in kisten van 40-50 kilogrammen inhoud.

Uit platte ongedekte stukken zongenaamde Huanuco van Peru (Quinquina IUuanuco sans epiderme) werden verkregen 6 grammen zwavelzure cinchonine. De bleekgele (Janne pälc) platte Huanuco, leverde 6 grammen zwavelzure chinine en 10 grammen zwavelzure cinchonine op. De gedekte pijpstukken (roulé avec épiderme) leveren 2 grammen zwarelzure chinine en 8-10 grammen zwavelzure cinchonine op (1).

Deze Iluanuco-kina wordt ingezameld in de bosschen van de provincie Iluanuco en ten noorden van Lima. Uit de haven van Callao wordt zij uilgevoerd in seroenen van $70-75$ lilogrammen. Zị heeft in haar uiterlijk aanzien eenige gelijken is op de kina van Bolivië (d. i. de Galisaya), zoodanig, dat men liaar meermalen daarmede heeft verwisseld, hetgeen vooral de platle stukien betreft. De pijpstukken, zoowel de bedekte als de naakte, maar vooral de eerste, zijn in de laatste jaren in groote hoeveelheid in den liandel gebragt.

Hier te lande wordt echter, men weet niel waarom, de Loxa verkozen.

Van de roode Kina is boven het gehalte an zwavelzure chinine opgegeven en er is hierbij alleen nog te roegen, of liever te herhalen, dat ook de geschiedenis van dezen uitmuntenden bast, wat zijn soorts-verschil of overeenkomst met andere meer bekende basten aangaat, bij velen nog als nict uitgemaakt wordt gehouden. De roode Kina wordt vooral in

(1) Detondie en Boucinadoat, pl. 4 ell 5, p. $2 \%$. 
de bosschen van de provincie Quito, maar ook, gelijk boven reeds is gezegd, in Nieuw-Grenada aangetroffen, alwaar zij 't eerst door Mutrs is ontdekt. Zij wordt urt de haverr van Guayaquil in seroenen of in kisten van 50-60 kilogrammen uitge voerd.

Haar aanzienlijk gehalte aan alcaloiden heeft haar sedert lang bij de geneeskundigen eene groote voorkeur doen genieten. De hooge prijzen echter en hare zeldzaamheid staan het gebruik van deze Kina aanıerkelijk in den weg. Nergens schijnt men den rooden bast zoo zeer op prijgs te stellen als in Nederland, waar men dien doorgaans bezigt, wanneer men de Kina in poedervorm wil aanwenden (hetgeen bij ons nog zeer gebruikelijk is), of bij het toedienen van een afkooksel van Kina-bast met zwavelzuur. De duurte en schaarschheid van dezen bast verklaart zich daaruit, dat die meestal werd genomen van dikkere boomstammen, die meer en meer verdwijnen.

Eene roode Kina, die de Franschen Quinquina rouge de Mutis de la Nouvelle Grenade noemen, staat nabij an die roode van Quito, welke als rouge vif wordt onderscheiden; naar deze levert cen belangrijk verschil op in chinine-gehalte, met de gewone roode Kina van Carthagena. De rouge de Mutis bevat 12-14 grammen zwavelzure chinine en 6-7 zwavelzure cinchonine per kilogram (1).

In onze botanische tuinen worden (zie hieronder) thans ook $n \log ^{\mathrm{g}}$ gekiweekt eenige andere soorten, welke lier, in betrekling tot hare basten, moeten vermeld worden en waarvan er mede reeds naar Java zijn overgebragt of nog overgebragt zulleu worden.

Zij zịn Cinchona pubescens Wedd. van welke eene ver-

(1) Deloyore on Bouchardat, pl. 15, p. $3 \pi$. 
scheidenheid a Pelletierima oplerer't den zoogenaamden Cusco-bast (Quinquina de Cusco Guib.) en de Arica-Kina (Q. d'Arica Guib.). Slechts de laatste verscheidenheid bevat sporen van chinine, namelijk 30 centigrammen op één kilogr. Deze C. pubescens komt voor in Peru en Bolivië. In den handel schijnt de Cusco-Kina met andere soorten vermengd voor te komen.

Een tweede soort is Cinchona ovala $R$. et $P$. Van deze komt de gewone vorm mede voor in de bosschen van de gematigde bergstreken der Andes van Peru en Bolivië, op eene hoogte van 1800-2300 meters. Eene verscheidenheid, welke WEDDELL noemt rufinervis, d. i. met roode bladnerf, kout roor op de hellingen der smallere valleijen en dus in de warmere streken van Zuidelijk Peru, in de provincie Carabaya en in Bolivië. Tot deze soort en hare verscheidenheden schijnen te moeten worden gerekend onderscheidene variëteiten van Loxa en Huanuco-Kina. De Heel Guibourt heeft een baststuk van deze soort van Cinchona, hem door Wedpels voorgehouden, erkend als die Kina, welke hij noemt Quinquina de Lima gris fibreux. Welle de waarde van die $C$. ovata zij, is wel niet met zekerheid uit te maken, zoo lang daarover niet meer licht verspreidt wordt.

Uit hetgeen wij hieronder zullen mededeelen, betreffende de missie van den Heer HAssikarL, zal blijlien, dat aan dien natuuronderzoeker bepaaldelijk was voorgeschreven, om, bij de inzameling van Kinaboompjes of zaden van Ginchonen, zich niet uitsluitend te bepalen tot de Calisaya, maar om zoo veel mogelijk alle soorten; welke hem zouden voorkomen, in te zamelen. Dit voorschrift had ten doel, om, ten anzien van eenige nog minder bekende soorten en hare produliten, nadere inlichtingen te bekomen, of die later door 
kultunr te verkirijgen. Men dient derhalve uit dit vorpunt hier te beschouwen de $C$. ovala $R$. et $P$. en enkele andere. De C. ovala is bepaaldelijk een bewijs van hoevecl belang liet is, om de aandacht zoo veel mogelijk op alle soorten to vestigen; lıetreen onder anderen blijkit nit de volgende woorden van Weddelt:

"Aucun Cinchona, si ce n'est le $C$. Condaminea, n'est aussi susceptible de varier avec le terrain et avec le climat que le $C$. ovcula, et c'est surtout dans l'écorce que ces variations sc fout sentir; elles se présentent tantôt daus la coulcur, tantôt daus sa structure même ou dans les deux à la fois. Dans quclques circonstances, la physionomie du quinquina ovata se rapproche tellement du quinquina Calisaya, que c'est arec difficulté que l'on l'en distingue."

- "Un même individu du. C. ovata produit fréquemment de chaque côté de son tronc des variétés distinctes d'écorce. "

- "Jc ne doute pas que beaucoup des quinquinas roulés de Loxa et de Huanuco ue doirent se rapporter à cette espèce (e'est à dire au Cinchona ovata.) "

Ik ben door de bijzondere welwillendheid der Hoogleeraren van het Muséum d'Histoire nalurelle to Parijs, in staal geweest om aldaar de voorwerpen en basten, door Dr. Wedect in ZuidAmerika verzameld, te bezigtigen. Ik heb later door de goedheid van den Heer T. Mastenbroek, te Amsterdam, aan wien specimina van de bastsoorten van WEDDELL zijn ten geschenke gegeven, de gelegenheid gehad om die voorwerpen met opzet na te gaan. Hicrdoor en bovendien door de welwillende inlichlingen van dezen onzen ijverigen landgenool, zag ik mij in staal gesteld, oin inij van de juistheid van lıetgeen WEDDELL (die thans boven alle anderen onze autoriteit moet ziju) in zijne Hisloire naturelle des Quinquinas, omtrent die C. ovala mededeelt, door cigen aanschonwing, nader en bij herhaling te overtuigen.

Ik vinde nanelijk onder die specimina niet minder dan twaclf basten, welke tot de Cinchona ovata betreking hebben en onder die basten ziju er werkelijk goede, name- 
lijk die overeenkomen met of zeer nabij komen aan de Calisaya, de Loxa, de flava Americana, enz. Andere van deze specimina behooren tot de minder waardige, gelijk nit de bijzondere mededeeling omtrent dezelvo en de daartoe betrekking hebbende plaatsen in het greschrift van Wrodell kan blijken (1).

Eindelijk is te Leiden nog voorhanden eene soort als Cinchona lancifolia Mutıs benoemd, mede uil zaad opgekomen, volgens Weddell $G$. Condaminea et lancifolia, van welke de vezelige Carthagena lina ( $Q$. orange de Mutis, volgens Gurb.) wordt afgeleid, en waarvan de zaden nit Zuid-Amerika zijn herwaarts overgebragt en wel uit Nieuw-Grenada,

(1) Zie hier de bijzonderheden omtrent de .mij door den Heer Mastersroek afgestane voortverpen, nit de eolleetie van WEDNELL.

N". 1. Cinehona ovata $R$. et $P$. var. rufinervis. De bijliggende bast is eene soort van Calisaya-Kina (volgens Mastenbroek).

No. 6. Idem. De bijliggende bast heeft tot bijsehrift: cascarilla morada ordinaria. Eene bijsoort van Calisaya. WEDDELL zegt el van, p. 62 : "Dans "les parties du Pérou que j’ai visitées, les belles qualités du Quinquina " ovata roulé passent pour du Calisaya. Quant aux variétés oldinaires, "quelle que soit leır forme, on les appelle Cascarilla morada " enz.

No. 9. Idem. Heeft tot bijsehrift: Provincie Carabaya. Eene bijsoort van Calisaya. (MAst.)

No. 57. Idem. Heeft tot bijsehrift: Cascarilla Zamba Morada. Wedpeul zegुt er van: "C'est surtout dans la provinee de Carabaya qu'elle se reenille " et elle y sert habitnellement ì sophistiquer le quinquina Calisara."

No. 67. Idem. Heeft tot bijsehrift: Cascarilla najaranda Nrodd. Dipart. Cuzco. Perm. De bijliggende bast heeft veel van Loxa-lina. (MLAst.)

No. 66. Idem var. erythroderma Wedd. Met dezelfde bijsehriften en ran denzelfden oorsprong. De bijliggende bast is houtaelitig als China nora. (Dezelfde.)

No. 85. Idem. De bijliggende bast is de zoogenamude gele Amerikaansche kina. (Dezelfde.)

No. 92. Idem.

No. 93. " 1 De basten niet wel te bestcumen.

No. 78. "

Nn. 79. " Bijsoorten ran de eenc of andere kina van den liandel, doch

No. 80. " $\mid$ niet wel te bepalen. 
Van deze C. Lancifolia Mutis komt eene zeer goede bastsoort, welle, volgens Delondre en Boucirardat, 15 -16 grammen zwavelzure chinine en 8-10 grammen zwavelzure chinchonine per kilogram oplevert (t. a. pl. p. 35).

Men zal zich uit het boven (bladz. 18) door ons medegedeelde herinneren, dat Mutis van deze zijne soort de oranje kina heeft afgeleid.

De hooge waarde van de kina-basten van Nieuw-Grenada, op welke het ecrst is gewezen door Mutrs, blijkt onder anderen uit de resultaten van scheikundige ontledingen van Delondre (p. 32), en waaruit gereedelijk is op te maken, dat men die basten niet genoeg lian op prijs stellen. Zeer te regt zegt dan ook Delondre:

"Nous devons la découverte de tous les Quinquina's de eette partie de l'Amé"rique du Sud ì MUTIs, médeein Espagnol. Maintenant qu'ils sont l'objet d'un " commerce si important et que leur valeur est bien constatée, nous ne pensons "pas qu'il soit utile de faire ressortir de noureau le serviee immense que Muris " a rendu à la seience et à la médieinc."

Hoe meer chinine een bast bevat, des te meer kan hij gerekend worden een koortsdrijvend vermogen te bezitten en des te kostbaarder is lij te achten. De waarde van de kina als geneesmiddel en als artikel van handel is dus afhankelijk van de hoeveelheid van dit zout, hetwelk daaruit is te verkrijgen. Dat goede Calisaya dus boven aan moet staan bij den invoer in onze Kolonie, dit spreekt wel van zelve. Naar de bekende resultaten van de onderzockingen der basten op dit chinine-gehalte, zou men bijna tabellarisch kunnen voorstellen, in welke mate de soorten meer of minder dit koortsdrijvend vermogen bezitten, zoo ver dit van het gehalte aan chinine afhankelijk is (1).

(1) Wij laten hicr volgen eene tafel van de versehillende en roornaamste basten, in betrekking tot hun gehalte aan de dusgenaande kina-zouten, volgens DELONDRE EN BOUCHARDAT. 
Men zou echter geheel te onregte, uit het mindere chinine-gehalte, tot het nutteloos zịjn van sommige bastsoorten, 200 als de Loxa- en de Huanuco-kina besluiten. Integendeel, al rekent men de overige soorten van basten, om het min-

Zwav. Chit. Zwav. Cinch.

Per kilogram.

Bolivie.

Pérou.

Nouv. Grenade.

Côte d'Afrique.

Equateur.

Nour. Grenade.

Brésil.

Nouv, Grenade.
Quinquina Calisaya, plat, sans épiderme $30-32 \mathrm{gr} .6-8 \mathrm{gr}$.

roulé, avec " $15-20$ " $8-10$ "

Carabaya, plat, sans " $15-18$ " $4-5$ "

" roulé, avec " $8-10$ " $5-6$ "

rouge de Cuzco plat, sans " 4 " 12 "

" " " roulé avec " " $6-8$ "

Huanuco, plat sans " 612 " 12

" jaune pâle " $6 \quad$ " 10 "

" roulé avec " 2 " $8-10$ "

de Jaen

10 " 4 "

$20-25$ " $10-12$ "

$15-18$ " 5-6" 6

8 " 6 "

2 " 10 "

$3-4$ " 30 "

jaune de Guayaquil

" orangé roulé Calisaya 18 " $4-5$ "

" de St. Fé de Bogota 30-32 "3-4" *

Pitayo

Carthagène ligneux

jaune orangé de Mutis

$20-25$ " $10-12$ "

20

$15-16$ " $8-10$ "

rouge de Mutis

jaune " "

rosé

Maracaybo

de Cuzco

des Iles de Lagos

gris roulé

faux rougc brun

inféricurc rouge pîle

blane

12-14 "6-7"

12-14 " 6-7"

18 " 4 "

10 " $3-4$ "

0,50 " 0,40 "

- " 0,60 "

0,60 " -

0,18 " 0,02 "

0,06 " 0,12 "

Taux quinquina 
dere gehalte van de meermalen genoemde zouten, te zijn van mindere waarde en dus van ondergeschikt belang, zoo zijn daaronder toch vele zeer nutlige basten, die door de genees: kundigen steeds utet goed gevolg, zells bij periodieke ziekten, ntaar bovenal om het tonisch en opwekkend vermogen worden aangewend. Tegen de mindere achting van die basten liebben bekwame natumr- en geneeskundigen teregt gewaarscliuwd (1). Het nut dier basten is door eene zeer lange ondervinding bevestigd; want de kinabasten in let algemeen behoorden steeds onder de voornaamste geneesmiddelen, toen er nog geene zouten van chinine en cinchonine bekend waren. $\mathrm{B}$ ij de beoordeeling van deze liwestie verlieze men vooral de waarde der cinchonine niet uil het oog.

Daargelaten nu nog of nien de Loxa- en de Huanuco-kina, om het geringere gehalte of het gebrek aan chinine, minder te achten hebbe, moet men niet voorbijzien dat zij belangrijke artikels van lıandel zijn. Een voornaam handelaar te Amsterdam heeft mij inedegedeeld, dat hij in 't begin dezes jaar's groote verzendingen heeft gedaan naar Rusland en dergelijke voor Japan gereed maakte. Ofschoon nu voor eenige jaren haar gebruik wel door de chinine verdrongen werd, zoo kan men toch inet zekerheid aannemen, dat het gebruili dagelijks meer en meer toeneemt, hetgeen vooral door de staten van de leverantiën aan de hospitalen zou zijn te hewijzen.

In verband met de thans op Java reeds aanwezige of derwaarts uit onze botanische tuinen nog over te brengen soorten en variëteiten van Cinchonen, is in liet hierboven medegedeclde slechts gehandeld over eenige voorname soorten vau kinabasten. Maar er is nog over één punt, vooral ter gelegenheid van de.cinchonine-houdende basten te spreken.

(1) Ossian, Henry en Delondre, in Nov. 1552 bij de Académic Impériale de Médicinc, en Soubernas in het Joumal de P'hamicic, Oct. 1552. 
Is het namelijk niet te verwonderen, dat men zóó weinig waarde schijnt te hechten aan de cinchonine? En dit niettegenstaande het cinclionine-houdende basten (Loxa-kina welligt rermengd mel roode lina, die eene mindere hoeveclheid chinine dan de Calisaya beval) schijnen geweest te zijn, die van ouds de grootste vermaardlıeid als koortsdrijvende kina-basten hebben gelıad? Het sclijunt inderdaad dat men aan dat alcaloïde geen genoegzaam regt laat wedervaren; terwijl toclı de getuigenis van geneeskundigen, die gezag verdienen, dat is, om de nuttigheid van die stof, vooral in hare verbindingen met zwavelzunr of zoutzun te staven (1). De waarnemingen wegens haar nut bewijzen, dat zij, wat hare werkzaamheid aangaat, voor de chinine en hare verbindingen niet belıeft onder te doen. De behandeling van tusschenpoozende loor'sen in de laatste jaren, door onderscheidene Fransche artsen, schijnt regt te geven om de cinchonine als tegenwoordig meer dan vroeger op hare juiste waarde geschat, te beschouwen. Dit zal de cinchonine-bevattende basten meer op prijs doen stellen, het zal goede basten, dic tot hiertoe te weinig geacht zijn, doen waarderen gelijk zij verdienen en bij het gevaar, helwelk ontstaat uit de hand over hand toenemende vermindering van chinine-houdende basten, aan welke men wel zeer te regt, maar toch al te uitsluitend als geneesmiddel eene hooge waarde toekent, waarborgen, dat men, als cenmaal de groote voorraad van deze laatste in Zuid-Anerika zal zijn verminderd of zal ontbreken, een plegtanker zal hebben en behouden, op 't welk de geneesheer niet zonder' reden zijuc hope kan vestigen.

De Hollandsche Maatschappij van Wetenschappen te IIaar-

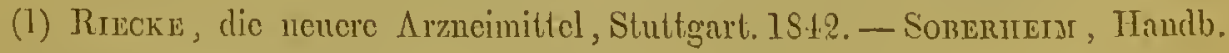
der pract. Arzncimitlellelire, 1551, 427.

Detontire ch Bouchardate, 1. с. p. 4.3. 
heeft, naar aanleiding van de boven vermelde omstandiglıedeı, in hare jaarlijksche Algemeene Vergadering, gehoudeu den 19 Mei jl., tot het voorstellen van de volgende vrage besloten :

"Sedert de uitvinding van de ehina-alealoïden. hebben de geneeskundigen, wegens hare koortsverdrijvende eigensehap, de voorkeur gegeven aan de zwavelzure ehinine of andere ehinine-verbindingen boven die van de einehonine.

"In de laatste jaren is men tot de ervaring gekomen, dat in Zuid-Amerika de beste kina-soorten, iwaaronder inen die verstaat, welke eene grootere hoeveelheid ehinine bevatten, sterk verminderen, zóó zelfs, dat men grond heeft om te vreezen dat de voorraad geheel zal uitgeput worden. Het is dus velen doelmatig voorgekomen om als febrifuga meer aandacht te sehenken aan andere kina-soorten, die daarentegen bovenal of bijna alleen einchonine bevatten.

"Hierbij zou dus de vraag verdienen in aanmerking te komen, in welken graad de einehonine en hare verbindingen het koortsdrijvend vermogen bezitten, om als surrogaten van de ehinine te kunnen dienen. De Maatsehappij stelt derhalve als prijsstoffe voor: "Een geneesknndig onderzoek omtrent de einehonine en "hare verbindingen." "

$W_{i j}$ vleijen ons, dat zij hierop eene goede beantwoording zal ontvangen.

Bij de uiteenzetting der Kina-geschiedenis komt eene allergewigtigste vrage in aanmerking, namelijk, betreffende den handel in de Kina; maar welke ik moet bekennen, niet te kunnen beantwoorden.

Er werden tol dat einde vele bronnen, maar te vergeefs, geraadpleegd, om namelijk te weten, welke de juiste hoeveelheid Kina-bast zij, die jaarlijks uit de verschillende havens van Amerika wordt uitgevoerd. Men kwam hierbij vaak tot de meest tegenstrijdige opgaven en slechts van ééne enkele dezer republicken bestaat een berigt van den heer Weddell, namelijk in zijne Voyage dans le Nord de la Bolivië, chapitre XIII, alwaar hij zeer belangrijlie mededeelingen heeft gegeven over dit gewigtig onderwerp en vooral berigten over den Kinahandel in Bolivië zelve en de verschillende compagniën voor de exploitatie in dat land:

Deze nu komen op het volgende neder: 
Eerst omstreeks 1776 (zoo luidt de mededeeling van W.) kwamen de Kina-basten van 't zuiden van Peru op de Europesche markten, terwijl zij tot dat tijdstip alleen haren voorraad hadden getroliken van de bosschen van Loxa. Omstreeks denzelfden tijd werden ook die van Nieuw-Grenada aangeboden; veel later kiwamen die van Bolivië met al de eerstgenoemde in concurrentie, welke sedert de uitvinding der chinine, vooral voor den hankel der overige staten, bedenkelijk werd, ondat het bleek, dat de Calisaya de overlıand verkreeg boven alle andere basten. De bosschen van Bolivië zijn inderdaad de eenige plaatsen, waar de natuur den Calisaya-boom in eene eenigzins grootere hoeveelheid heeft doen groeijen en het departement $\mathrm{La} \mathrm{Paz}$ is bovenal in dit opzigt begunstigd (1). Kort na dit tijdstip werden de bosschen zoodanig geëxploiteerd, dat men weldra, nabij de bewoonde plaatsen geene Calisaya meer vond; dat de markten overladen werden en de prijs zeer sterk daalde.

In 1830 beperkte de Regering den uitvoer tot zeker maximunı; doch vermits dit het doel niet deed bereiken, besloot men de exploitatie uitsluitend toe te staan aan eene nationale compagnie.

Het Congres besloot daartoe in 1834, maar de vastgestelde wet miste haar doel. De uitvoer werd nu weder rrij, maar op hare beurt vervangen door een besluit, waarbij de inzameling voor den tijd van vijf jaren werd verboden. Maar ook die maatregel werd, vóór het verstreken zijn van den termiju, ingetrokken en door een uitgaand regt van 12-20 piasters op ieder kiwintaal vervangen.

In 1841 kwam de generaal Ballivian aan let bestuur. Hij braght echter geenerlei wijziging aan den lina-lıandel. In dat

(1) MLen zic: Dr. H, A. Wennenu, Toyage dans le Nord de la Bolirië et dans les parties voisines du Pérou. Oct. Paris, 1S53, p. 235. 
jaar werd het Gouvernement gemagtigd om een kapitaal te negotiëren voor de oprigting van eene natıonale bank, dic al de kina, door het geheele land opgebragt, moest af lioopen en uitroeren en die betalen tegen zckeren tax, dien zij zelve zou bepalen in eventedigheid met lare fondsen en overeenkomstig de belangen der cascarilleros.

Het benoodigde kapitaal werd niet bijecngebragt en de Regering ging dus over tot eene publicke tocwijzing van het uitsluitend regt van exportatie voor cenen tijd van twec jaren. Nicmand echter bood zich daartoc aan.

In 1845 werd, na cenige wijzigingen, de monopolic toegestaan aan de heeren $D$. Tonge Tesanos Pinto en $Z Z^{\circ}$, voor de jaarlijksche som van 119,000 piasters, gedurende 5 jaren. Men zou 's jaar's slechts 4,000 kwintalen of 400,000 kil. uitvoeren. De geringe betaling voor de basten schijnt die compagnie zeer impopulair te bebben gemaakt. In 1849 werd haar privilegie ingetrokken.

De Heeren Aramayo en Co. verki'egen op 't laatst van 1849 op nieuw hel prrvilegic. Zij gaven een hoogeren prijs en hicrvan was het gevolg, dat zij met Kina werden overstroomd, die zij verpligt zouden geweest zijn te koopen, ware nict de Regering haar in deze crisis te gemoel geksomen, onder anderen door gedurende $\breve{5}$ jaren de inzameling te verbieden.

Deze impopulaire maatregel gaf in 't hinnenland groot misnoegen; hij werd niet geliandhaafd en daardoor werd de val der compagnie voorbereid, waarvan, kort daarna, het bestaan, in een congrès te La Paz gehouden, voor onwettig verklaard en waarbij hare ontbinding uitgesproken werd.

Eene volgende compagnic, die van de lieeren Pedro Blaye en $C^{\circ}$., is op hare beurt gevallen door overvoer van de markt en daling der prïzen. De laatste had namelijk tegen bijna gelijken prijs als de banco Aramayo opgekocht, en daardoor eenen enormen anvoer doen ontstaan. Er waren 
in de twee laatste jaren (vóór 1851), alleen uil de bosschen van Bolivië, meer dan 3 millioenen ponden Kina getrokken.

Hoe nu, bij deze enorme exploitatie, met de boomen geleefl werd, zal op eene andere plaats worden medegedeeld.

Wij weten, dat in rrocgere tijden Amsterdam mede de stapelplaals van den Kina-handel was. De lrandel van vele artikels wordt nu en dan (gelijk men weel) naar elder's verplaatst, maar gelukkig liomen andere artikels in hunne plaalsen. Hoezeer het ons leed doet, dat de Kina-handel thans niet meer voornamelijk te onzent haar middenpunt lieeft, worden er echter jaarlijks groote hoeveelheden aldaar en in onze andere groote handelstad Rolterdam ingevoerd.

Uit de statistieke opgaven in de jaren 1846-1853 van wege het Ministerie van Financiën beliend gemaakt, blijkt wel de waarde, maar niet de soort, noch de hoeveelheid ran in- en uitgevoerden Kina-bast.

- Hova van de waarde van den In-en Uitvoer van Kines, gedurende de jaren 1846-1853 (1), in en uit Nederland.

\begin{tabular}{c|c|c}
\hline JAREN. & INVOER. & UITVOER. \\
\hline 1846 & $f 193,494$ & $f 186,023$ \\
1847 & " 299,503 & " 276.481 \\
1848 & " 111,532 & " 101,715 \\
1849 & " 487,131 & " 472,944 \\
1850 & " 898,110 & " $\$ 92,591$ \\
1851 & " 568,853 & " 564,303 \\
1852 & " 722,409 & " 711,152 \\
1853 & " 523,827 & 512,724
\end{tabular}

(1) Zie: Statistick van don Inandel on de Schecpvaart van het Koningrijk der Nederlanden, over de jaren 1846-1853, nitgegevon door liet Departement. van Financiëu. 
Hetgeen dus in het land in die jaren is gebleven, zou rijn ecne waarde van

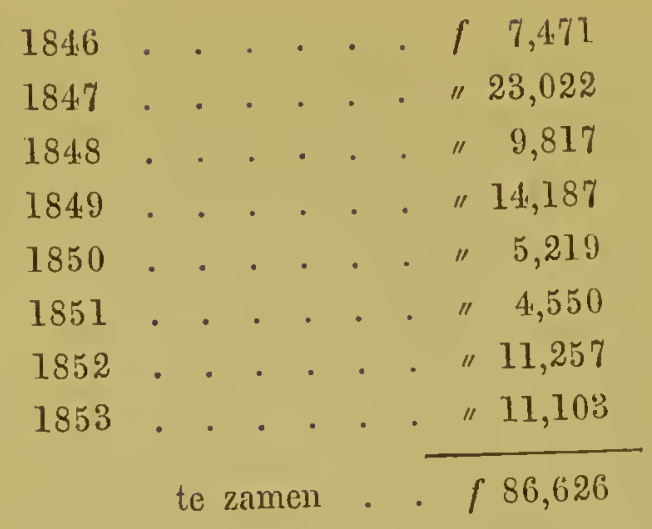

Hetgeen gemiddeld zou bedragen voor elk jaar eene waarde aan Kina van / $10,828 \frac{1}{1}$.

Aangenomen dat de aangevoerde soorten, noch de beste noch de minste in waarde zijn geweest, maar toch eene goede soort, bijv. de Huanuco, die in de laatste jaren heeft gevarieërd in prijs van 70 cents het $\frac{1}{2}$ kil. tot $f 1.40$, en verder als gemiddelden prïjs van 1 kil. $f 2.10$ stellende, dan zou dit ongeveer vertegenwoordigen cene hoeveelheid Kina van 5,156 kil. per jaar.

Het is evenwel te betwijfelen of deze berckening eene juiste maatstal voor het gebruik van Kina in Neferland zij; hoezeer het aan den anderen kant bekend is, dat de Kina-bast zelf (maar dit geldt van de beste soorten) sedert het algemeen aanwenden van chinine, niel zoo algemeen gebruikt wordt.

Mijn geẻerde ambtgenoot Prof. Mrouel heeft mij wel willen dienen met ecnige opgaven van de hoeveelheid zwavelzurc chinine, ingekocht alleen voor de stads. en gasthuizen te Amsterdam. Deze was roor 1850 eene hocveelheid van 10 kilogr.; voor 185 1 bedroeg zij 8 kilogr.; voor $1852-3=16$ kil.; voor $1854=10$ kil.

Alleen voor 's Rijks Magazijn van geneesniddelen, alzoo voor het Nederlandsche Leger en de Marine hier te lande en 
in de Overzeesche Bezittingen van het Rijk ziju in de jaren 1850-1855 aanbesteed de volgende hoeveelheden zwavelzure chinine, die voor elk der jaren gelijk staau, met de achter die jaren vermelde hoeveelheden Calisaya- of Konings-kina, aangenomen dat daartoe Konings-kina is angewend, die per kilogram 32 grammen zwavelzure chinine gemiddeld nagenoeg oplevert. 1850 S0 kilogr. zwavelzure chinine $=2500$ kilogr. Kina.

$\begin{array}{rr}1851 & 75 \\ 1852 & 80 \\ 1853 & 75 \\ 1854 & 120 \\ 1855 & 140\end{array}$

De zwavelzure chinine wordt van buitenslands aangevoerd. Wij zien ook hier, na een lijdsverloop van vijf jaren, eene verdubbeling van de verbruikte hoeveelheid.

Meer dan $\frac{3}{\frac{3}{k}}$ van deze aanbestede hoeveelheid wordt naar Oost-Indië uitgezonden. Ik ben de kennis van deze bijzonderheden verschuldigd aan de welwillendheid van den heer Dr. SNabilié, Inspecteur-Generaal der Geneeskundige Dienst.

Den gewonen jaarlijkschen invoer van Kina in Engeland, vinde ik bij Srmuovds opgegeven als afwisselende tussclien 225,000 en 556,000 (Ned.?) pond, van welke, voor' 't gebruik bimnenslands, onstreeks 120,000 Ned. pond wordt gebezigd.

Zoo de opgaven van Simuonos juist zijn, zou men in Parijs 's jaars produceren 120,000 (Ned?) oncen zwavelzure chinine, die vertegenwoordigen eene loeveelheid van 575,000 kilogrammen aan Galisaya-Kina en eene geldswaarde van drie millioenen driemaal honderd en vijf en zeventig duizend gुulden, berekend naar den tegenwoordigen (16 April 1855) prijs dezer Kina te Amsterdam (1).

Volgens eene opgave uit eene officiële bron, vernam ik van

(1) De prijs der Calisaya was 16 April j.l. to Amsterdam $f 4.50$ per half Ned. pond (Mastenkioek.) 
de statistiek der Kina in Frankrijk, hetgeen volgt in de hier onderstaande tabel:

Iloeveelheden Kina-bast in Frankrïk ingevoerd, gedurende de jaren 1849-1853 ingeslolen.

Jaren. $1849 \quad 1850 \quad 1851 \quad 1852 \quad 1853 \quad$ Totaal.

Algemeene $\left\{\begin{array}{llllll}\text { Kil. 272,924 269,071 } & 404,866 \quad 458,215 & 409,475 & 1,814,551\end{array}\right.$

handel.

Spcciële

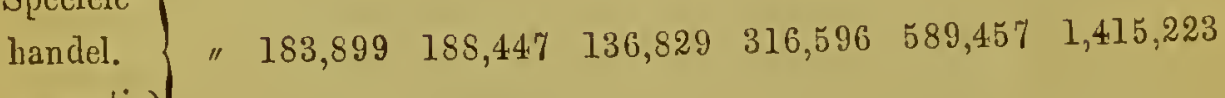
(consumtie)

Hieruit blijkt, dat de invoer en het verbruik in Frankrijk aanzienlijk toenemen. Het verschil toch van den invoer van 1849 met 1855 , dus van slechts vijf jaren, bedraagt 156,551 , en dat van het inlandsch verbruik in dezelfde jaren 405,555 hilogrammen.

Ten gebruike van het Fransche leger heeft men in 1855 eene hoeveelheid van 600 kilogrammen zwavelzure chinine ingekocht en in 1854 niet minder dan 1100 kilogr. Dil aanzienlijk verschil laat zich verklaren uit de groolere behoeften vool het leger in het Oosten.

Ik waag geene poging om de bovenstaande en andere opgaven met die van Simmonds in verband te brengen en ik kan slechts losse data aanvoeren, zoo als ze ter mijner kennis zijn gekomen.

Parijs en welligt andere steden van Frankrijk, voorzien zeker een groot deel van Europa van zwavelzure chinine.

Engeland bijv. ontving van daar, in

$1848 \cdot 3,856$ oncen $=$ aan cene geldswarde van $5,395 \mathrm{pd}$. st.

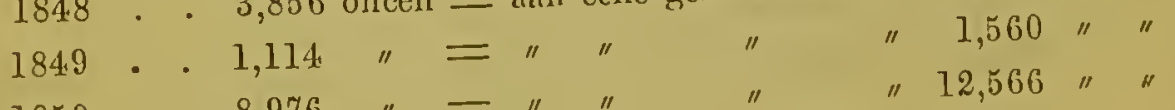

$1851^{\circ} \cdot 7,605 "=" 1 "$

In 1850 werden bovendien uit Frankrijk in Engeland in- 
gevoerd 489 centenaars Kina tegen 6,840 pd. st. In 1851 1,128 centenaars, tegen 15,787 pd. st. (1).

Srumonds berigt, maar hij geeft niet aan op welken grond hij zulks doet, dat de uitvoer van kina jaarlijks, en wel in de laatste jareı, eene waarde van twee millioen guldens beliep. Hij voegt er niet bij, of dit een uitvoer uit Peru of uit Bolivië, dan wel uil Zuid-Amerika in zijn geheel is.

Wij kunnen niet anders dan ons over het gebrek aan details in eene zoo gewiglige zaak en in een anders voortreffelijk geschrift verwonderen. Men schïnt er nog verre van af te zijn om de hooge waarde van eene goede statistiek, als basis voor économie politique, in te zien.

Er zijn, behalve te Parijs, in onderscheidene groote steden van Duitschland, maar ook in Engeland en Noord-Amerika fabrieken van zwarelzure chinine.

Door de welwillende mededeeling van den chef van een der voorname Amsterdamsche huizen, den heer T. Mastenbroek, an wien ik de ervaring en kennis van onderscheidene informatiën ben verschuldigd, is mij berigt, dat een der bekende fabriekanten van zwavelzure chinine in Duitschland, voor weinige maanden, commissiën voor Petersburg en Weenen had uit te voeren, waarvoor hij 80,000 kilogrr. kina-bast behoefde. Men verlieze echter niet uit hel oog, gelijk reeds is aangemerkt, dat de oorlog in het Oosten thans eene buitengewone consumtie vordert.

Bij de onvolledige uilkomsten van statistieke nasporingen, kan men echter met volle zekerheid tot deze resultaten komen:

1. Dat de uitvoer van de kina uil Zuid-Amerika ongeloofelijk grool is;

(1) The Commercial products of the regetable kingdom, by P. L. Sumoxins, 1854, Oct.

Dit morkwardige bock verdicnde in de haucten te aijn van ieder, dic in den handel en de kennis der produkten belang stelt. 
9o. Dat de produclie dumratan niet evenredig kan ziju aan te exploilatic;

$5^{0}$. Dat het te vreezen is, dat, zonder de aanwending van gepaste middelen om zulks te verhoeden, eenmaal een tijdstip zal komen, warrop de beste soorten niet meer zullen zijn te verlirijgen.

In het $\mathrm{II}^{\mathrm{a}}$ gedeelte van deze mededecling zal dit nader worden aangetoond. 


\section{DE OVERBRENGS' VAN DEN KINA-BOOM NAAR JAVA, OP LAST VAN HET NEDERLANDSGIIE GOUVERNEMENT.}

Waren deze aanteekeningen alleen voor de geleerde wereld bestemd, dan zou liet in de vorenstaande bladzijden voorģedragene eene grootere volledigheid moeten hebben, dan waarop het $n$ u behoefde of beöogde aanspraak te maken, terwjjl daarbij niets anders werd bedoeld, dan om elken niet-geleerden inaar beschaafden en belangstellenden lezer te doen inzien, wat Kina is, van welke waarde $\mathrm{z} \ddot{\mathrm{j}}$ is voor de lıumaniteit en van welk standpunt de Nederlandsche Regering is uilgegaan, bij lietgeen zij in deze belangrijke zaak, vooral sedert liet jaar 1851 heeft tot stand gebragt.

Indien dit opstel zulks duidelijk en bevaltelijk zal hebben voorgesteld, dan is zijn doel bereikt. Het zou, tot groot leedwezen van den steller, in het tegenovergestelde geval, gemist zijn. Het was noodzakelijk in sommige punten ran wetenschappelijken aard uitvoeriger to zijn dan anders noodig of wenschelijk was, daar de meeste leken (en wie zou dit misduiden?) met specialiteiten uit liet gebied der natuur- en geneeskundige wetenschappen veelal niet bekend zijn. Aan den anderen liant daarentegen was liet noodig zich te beperken. Icr vermijding van eene te groole nitvocrigheid. 
Wij weter, sedert de vroegste wetenschappelijke berigtrevers over de Kina, dal er door de bewoner's van Zuid-Anerika niels wordt gedaan our het onbeperkt inzamelen, wij zouden bijna zegrgen, berooven van de Kina-bosschen, tegen te gaan. Het is bijna als of deze zaak de Regeriugen van die Staten niel ter harte gaat. Aan aankweeken denkt niemand en het Openbaar Gezag schijnt zich daarmede ook niet te bemoeijen of is welligt daartoe niet bij magle. Tot dit laatste zou men bijna besluiten, als men nagaal dat de Kina-streek, volgens Wedderl, eene uitgestrektheid heeft van 2,000 vierkante mijlen. Men ziet toe dal ongehoorde massa's worden uitge. voerd; ja, wal meer is, dat er nu en dan geheele bosschen worden afgebrand! Het lian den Peruanen en Bolivianen inlusschen evenmin als an de Europeanen onbekend zijn dat de hoeveelheid vermindert, en dat de boomen, die men bij duizenden velt, niet zoo spoedig door anderen, die hunne plaatsen zouden kunnen vervangen, worden opgevolgd. Wie de Andes afdaalt, om zich in de bosschen, waar de Kina-boomen groeijen, te begeven, vindt als 't ware reeds van verre zijıen weg, op het geluid van de slagen van den bijl, waarnıde de cascarilleros die schoone boomen ongenadig en op eene roorbeeldeloos ruwe wijze, omhoúwen. Die ruwe handelwijze zelve werkt niet alleen noodlotlig voor de toekounst, maar alle berigten luiden eenstemnig, dat eene ongeloofelijk groote hoeveelheid bast op de meest roekelooze wijze te loor gaat.

Deze omstandigheden hebben liet treurige gevoly, wat reeds door dE LA Condame als magelijk voorzien en door alle latere reizigers bevestigd is, namelijk een' ziglbaren teruggang van de hneveelheid Kina-boomen.

Ifet is van zoo veel belang te achlen om deze omstandigheid in alle bijzonderheden te doen wilkomen, dal het noodig is gerelicnd hieronder, en dit wan liet gepast is met de 
ergen woorden der berigtgevers, te laten volgen, wat dienaangaande is aangeteeliend.

Don Avtronio de Uluoa (1) waarschuwde, ruim dertig jaren na de la Condaure, reeds tegren het bederven van de Kinabossclien, en stelde voor dat men tegen dat misbruik prohibitieve maatregelen zou nemen.

Dit heeft het Gouvernenent van Bolivië echter zeer laat ingezien, want eerst zes-en-zestig (!) jaren later, namelijk in Januarij 1838, werd een besluit nilgevardigd, waarbij het werd verboden gedurende den tijd van 5 jaren Kina uit te voeren.

Pereira (2) maakit de opmerking, dat, daal deze boomen slechls op een gedeelte der aarde voorkomen, en er geene zorg wordt gedragen voor humne aankweeking, het geenszins te verwonderen zon zijn, zoo deze basten na verloop van tijd uit den handel verdwenen.

Steversor (3) verklaart, dat, wanneer het Gouvernement van Amerika geene zorg aanwendt om den Kina-boom te behouden, hetzij door het omvellen der boomen te verbieden, of door de Gezagroerders der onderscheidene gewesten te verpligten om maatregelen te nemen, opdat de boomen niet vernieligd worden, het alsdan te vreezen zal zijn, dat dit voortreffeligk voorlbrengsel der nieuwe wereld gehcel zal UITGEROEID worden!

WeDdell verlilaart in de Introductic van zijne Ilistoire

(1) Schrijver van de Notitias $\Lambda$ mericanns, vol. I, 1772, 8०. Zic ook Hooker's Companion to the Botanical Magnzine, I, 247.

(2) The Filements of mat. med. and Therapcutics, bij Jonatran Perenra. Ill El. vol. 11, part. 1I, London 1853, p. 1605 sqq.

(3) Narrative of twenty Yenrs Residence in South Aucrica, 1I, 60. 
- naturelle des Quinquinas (p. 3), dat hij vooral zijue andacht heeft gevestigd op alle soorten van Cinchonen. Hij zegt:

"L'immcnse aceroissement pris par le commerec des quinquinas dans "ces partics, au détriment des ancicunes forêts, rendait en quelque sortc "néeessaire un travail ̀̀ leur sujet. A une époque aussi où la consomma"tion de ces écorces, et surtont de leur prineipc fébrifugc, la quinine, "devient de plus en plus cousidérable, je crois qu'il peut être utile d'ap"peler l'attention sur les éeorces qui, un jour, devront remplnecr le quin"quina Calisaya, dont l'épuiscment devient de plus en plus immincnt. Cos "espèees, si elles sont bcancoup moins riches en principes aetifs, nous "offrent encore, par leur abondance, quelque sécurité contre la chance "prochaine de nous voir privés du médicament le plus précieux du règne "végétal."

\section{Zie verder aldaar p. 7.}

"Aujourd'hui, pour rencontrer des écorces de bonnc qualité, il faut aller, "eomme je l'ai fait, à une distance de huit à dix journées des lieux habités."

En p. 15.

"Il faut bien le reconnaître, lc mode d'exploitation de ce produit pré"cieux semble devoir rester toujours à la merci des demi-sauvages qui la "pratiquent; et si on ne trouve pas quelque moyen efficace de contreba"lancer cettc puissanee destructricc, nos descendants auront inévitablement "la douleur, sinon de voir s'éteindre les différentes races de Quinquinas, "du moins de les voir devenir d'unc cxtrême rareté. - L'opinion de ccux "qui voient les forêts se repcupler par les semis et les rejets partis de la "Southe des arbres abattus cst bien plus conforme à la vérité; mais, comme on "a pu le voir, cela ne peut sc vérifier que jusqu’à un ccrtain point. Trop souvent, "en effet, la souchc massacrée sans discernement, sans pitié, meurt arcc lc "trone qu'elle supportait; ct les r'cjets, quand ils se produisent, arrivés avec "une extrĉme lenteur ì un certain degré de dévcloppeinent, tombent ì "leur tour sous la hâche pour ne plus reparaitrc; il en cst de même dos "semis. Une surveillance cxercée sur les travailleurs, au moyen d'inspcc"teurs, empêchcrait sans doute jusqu'ì un certain point de tels vandalismcs; "mais, quoiqu'on en disc, une mesure sembable ne pcut mallicurcusement "avoir licu qu'en théorie. Il cst bicn différent, en cffet, d'inspecter un bois "de nos pays et d'inspecter une forêt dı nouvcau monde, surtont quancl "cettc forêt a unc ćtendue de vingt mille licucs carrées.

"En dófinitive, deux moyens seuls me paraissent capables d’être cm"ployés pour obvier ì la disparition trop rapide des arbres à quinquinia: 
"l'un est de limiter l'exportation à un chiffre proportionné à la puissance "productrice des forêts; le second est d'en fairc l'objet d'une eulture ré"gulic̀rc. Limiter l'cxportation serait sans doute le plus sûr; mais n'est il "pas à eraindre que la disproportion cntre la eonsommation ct la pro"duction ne soit déjì trop grande pour qu'il soit possible de rétablir la "balance; et nos besoins d'autic part, ne sont-ils pas devenus trop exi"geants pour se plier à des considérations qui ne regardent qu'un avenir "éloignć (I)? - Reste la ressouree de la eulture, et il faut l'employer. "S'il cst un arbre diguc d'être acclimaté dans une eolonie française c'est "eertes le Quinquina; et la postérité bénirait eeux qui auraient mis i "exécution une semblable idće."

\section{p. 32 .}

"La grande réputation du quinquina Calisaya l'a fait tellement reeher"eher qu'il devient d'une extrême rareté et il n'est pas doutenx qu'un jour "il ue disparaisse prosque complétement du commeree et qu'on ne soit "obligé de se eontenter enfin de quelques unes des espèces quc l'on mé"prise aujourd'hui. Dejà autour des lieux habités il ne se voit plus, pour rainsi dire qu'à l'état d'arbuste, et si par hasard quclque petit arbre est "resté inaperçı au milieu de la forêt, à peine sa eime s'élèvcra-t-elle, "que la hache l'amra aussitôt atteint. Quand, pour mon compte, j'ai voulu "voir cette espècc dans toute sa vigueur, il m'a fallu passer de longues "journées à pied dans les forêts, les traverser par des sentiers à peine "ouverts et éprouver quelques unes des fatigues qui sont le lot commun "des pauvres cascarilleros."

(1) "A l'appui de celte manièrc de voir, il me suffira de citcr l'cxcmple de la com"pagnie de La Paz à la quelle le Gouvernement Bolivien a concédé le monopole du "commerce des quinquinas de la Bolivie, avec la faculté d'en cxporter annucllement "4000 quintaus ou 40,000 livres espagnoles, ct qui cepcodant n'a pu se coutcuter de "ce chiffre imposant, puisqu'on l'accusc en cc moment d'avoir dépassé de bcancouj' "scs droits. Quc sernit-cc.donc si les restrictions étaient enlevées complétenent, comme "ccla existe du reste partout aillcurs, ct notamment au Pćrou, oil les cxportations se "sont ćlcvécs, pendant certaincs annécs, ì des quantités vrniment fabulcuscs. D Dans "la Nouvelle Grenalc, au moment oì la rnge de l'exploitation des ćcorces étnit ì sou "plus liaut degré, c'est-ì-dire au commenecment de ec siècle, la quantité d'écorecs "cmbarquiécs dans le scul port de Cnrthagène s'est élevéc, ell 1806 sculcment, an "chiflre ćnorme de 1,200,000 livies; nujourd'luni, par contre, on en exporte ì peine "quelques arrobes." 
1. $5 \dot{3}$

" - La rarelé croissante du quinquina Calisaya porte saus cesse les "Casearilleros it y môler les écorces de plusieurs autres Cinchonas, et ils "réussissent en grénéral d'autant plus faeilement ì faire passer eette fraude "qu'on y est déjì presque accoutumé, et qu’ì moins d'une très grande "habitude il est bien difticile quelquefois de la découvrir."

p. $\overline{5} 7$.

" - On peut se faire une idée de l'immense eonsommation de eette "éeoree par le fait que la compagnie bolivienne en exporte annuellement, "sauf sophistieation, plus de 4,000 quintaux ou 4:00,000 kilogrammes. Il "est diffieile que les forêts sulfisent longtemps à l'alimentation de semblables "besoins."

\section{In het rapport van DE Jussieu (1) en zijne mede-gecom- milteerjen Richard en Gaudichaud, ter zake van eene Mémoire de M. Weddell, intitule Histoire naturelle des Quinquinas, bij de Académie des sciences uitgebragt, leest men bl. II, de vol- gende merkwaardige woorden:}

" - Il est néanmoins un point trop important à l'humanité pour que "nous n'y fixions pas un moment l'attention: e'est le défaut eomplet d'é"quilibre entre la consommation et la produetion des meilleures écorees de "Quinquinas, et la destrnetion assez rapide qui mennee les espèces les "plus estimées. MI. Weddell n'y aperçoit que deux remèdes possibles: l'un "qu'il reconnaît lui-même bien diffieilement applieable, e'est l'établissement "de sages pratiques qui présideraient à l'exploitation, en évitant toute "perte de eette substance précieuse, et d'une sage législation qui modé"rerait l'exportation. Mais eomment assujettir à ees pratiques les bûche"rons au fond des forêts du nouveau monde, et comment mettre ees res"trietions d'aecord avee les demandes énormes du eommeree, et surtout de "l'Europe, qu'on doit supposer réglées par le besoin même? L'autre remède "serait la multiplieation par la eulture: son sueeès serait sans donte assuré "sur toute eette vaste étendue où les Quinquinas eroissent naturellement. "Peut-on l'espérer hors de eette région, et quelques points de nos eolonies "offient-ils les conditions de elimat et de sol néeessaires ì sa l'étissite?

(1) Compte rendu des séanees de l'Académie des seienees XXVIII. Séanee du 11 Juin 1849. 
"On ne peut que recommander les essais, et c'est aux gouvernements it "les tenter; car', quoiqu'on n'ait pas des donnécs préciscs sur le nombrc "d'annécs clont l'arbre a besoin pour que l'écolcc ait toute sa perfcction, "et quc lc rendcment attcignc lc maximum, on peut calculer sur unc clurée "assez longue, ct les gains sont trop incertains ct certaincment trop éloignés pour eugager l'industrie particulic̀re dans de pareilles tentatives."

Bij Delondre (die zell de bosschen van Zuid-Amerika bezochl heefl) en Boucrardat (1) vinden wij het volgende:

" - Ruiz sc plaignait amèrement, en 1792, du peu de soins que les "cascarilleros apportaient à l'exploitation de l'arbre; M. de Jussicu, dans "son savant rapport sur l'Histoire des quinquinas de M. Weddell, appuie "aussi les observations contenues dans ce bel ouvrage à l'occasion de la "perte de la plus grande partie des écorces. Maintenant, que toutes les "loépubliques de l'Amérique du Sud n’ont plus qu’à faire un sage emploi "de l'indépendance qu'elles ont si chèrement acquisc, nous ne doutons pas "que les gouvernements de Bolivic, du Pérou, de l'Equateur et de la "Nouvelle Grenade ne portent toute leur attention sur la conservation de "la plus utile richesse de ces beaux pays, en régularisant les coupes des "forêts par des lois répressives.

"Ruiz dit encore avee raison que le coca, cet arbuste si précieux qui "formait antrefois des forêts impénétrables, a fini par être cultivé avec "grand soin et que la culture en a augmenté le produit et la qualité. "Pourquoi ne prendrait-on pas les mêmes soins de l'arbre de quinquina, "pour le conserver aux générations futures, au lieu de l'abandonner à l'in"souciance des Indiens, qui le détruisent d'année en aunée par la manièrc "dont ils l'exploitent."

pag. 21.

"Après une course des plus fatigantes, à travcrs millc obstacles et cx"posé à une pluic finc qui cut bientôt traversé uos vêtements, nous cn"tendîmes le retentissement des coups de hache de l'Indien qui était "arrivé au laut de la unontagnc bicn avant nous, cal nous étions exténués.

"Mais les coups de hache, qui étaicnt le signal de notre conquêtc, "nous rendirent les forces commc par enchantemcut, et nous fûmes bicutôt "auprès de ce magnifique ct grand arbre que je voyais pour la preurièrc

(1) Quinologie, p. 14, 21, en daarbij angchaald Voyage dans lc Nord do Bolivie, par Wednelt, 1852, chap. XXIX. 
"fois et qui était depuis longtenuss le sujet de mes rêves. Je restai en ucxtase devant ses belles écorces argentées, ses larges feuilles d'un vert "elnatoyant, et ses fleurs d'un parfum si doux, qui rappcllent un peu "celles du lilas.

"L'arbre n'est pas tombé tout de suite, il est resté comme suspendu "au milien des lianes et des arbres de toutc cspècc dont il était cntouré, "et qu'il a fallu abattre à une certaine distance pour quc notre conquête "si désircée pût s'ćtendre sur la terre et nous permettre de l'admirer ¿̀ "notre aise, de eouper des écorces du trone et des branches, et de mâ"cher les feuilles, les fleurs ct les fruits, pour $\mathrm{y}$ chercher ì des degrès "différents l'amertume des éeorces.

"En descendant de la montagne, je ne pus m'empêcher de déplorer "l'indifférence avec laquelle l'Indien portait des coups de hachc à une "eertaine élévation du sol pour n'avoir pas la peine de se courber. Il cn cst "de même dans toutes les forêts de l'Amérique du Sud; ils abandonuent "aussi le tronc ì la naissance des branches, et l'ou peut calculer que, "génćralement, on ne récolte pas la moitié des éeorces que ehaque arbre "pourrait produire."

\section{In zijn Voyage au Nord de la Bolivie (1), zegt Weddel het volgende:}

"On m'a raconté que, dans les forêts à quinquina nouvellement décounvertes du département de Cochabamba, on se contentait très-solvent, "pour ne pas avoir la peine de couper l'arbre, d'en retirer l'éeorce jusqu'ì "la hauteur où la main pouvait facilement atteindre, et, si l'arbre était "abattu, on négligeait de prendre toute la partie de son écorce qui se "trouvait du eoté du sol, afin d'éviter le travail de retourner lc tronc.

"Quoiqu'on en dise, les forêts de la Bolivie, toutes riches qu'elles "sont, ne peuvent résister longtemps à des attaques contiuucs du.gemre "de celles qu'elles ont eu ì subir réeemment. Celui qui, cn Emope, roit "arriver ees masses ćnormes ct toujours eroissantes de quinquina, peut "bien eroire qu'il en sera toujours ainsi; mais celui qui eherche, dans alcs lieux mêmes où le quinquina se produit, ì savoir ce qui en est, "se voit obligé de penser autrement. Il suflit cffectivement d'un seul fait "pour montrer la diminution eonstamment progressive des arbres à quill-

(1) t. a. pl., p. 24. 
"quina (1), e'est qu'antrefois on en reneontrait partout aux environs des "lienx habités de la région, tandis qu'aujourd'hni, pour trouver un arbre "de quelqques dóeimètres de diamètre, il faut, en génćrnl, faire plusienrs "journées de chemin an sein des forêts. Or, ì moins que ees forêts ne "soient sans limites, ee qui n'est pas, ou que les arbres abattus soient "remplacés par d'autres, ee qui, par malheur, n’a lieu que très rarement, "eomment une exploitation eonduite comme eelle dont j'ai parlé pourrait"elle tronver à s'alimenter indéfiniment? Il est de tonte évidenee que "le quinquina ealisaya, si l'on eontinue à l'exploiter de la sorte, finira "tôt ou tard par disparaître plus ou moins eomplètement de nos marehés, "น̀ moins toutefois qu'on ne s'oceupe administrativement de sa reprodue"tion, et les espèces de quinquina plus ordinaires qui le remplaceront "finiront sans doute, à leur tour, par aroir le même sort."

Men vindt (2) in een vaderlandsch geschrift opgegeven, dat de Staat Bolivië alleen, in 1834, over de haven van Arica naar Engeland, Frankrijk en de Vereenigde Staten verzond 5,486 kivintalen Kina (vermoedelijk wel grootendeels Calisaya). In hetzelfde jaar verzond diezelfde Republiek $3,496_{2}^{1}$ kwintalen uit de haven van Islay naar Engeland, Frankrijk en Genua; alzoo te zamen $8,982 \frac{1}{2}$ kwintalen, gelijk staande aan 898,250 kilogr. Wij nemen dit over zonder de juistheid te liunnen waarborgen, hoewel wij evenmin reden hebben die te betwijfelen.

Behoefde men nog meer getuigenissen om zich reeds sedert lang te hebljen kunnen overtuigen van de schroomelijke ver. mindering en den teruggang der Kina-bosschen, hel steeds toenemende gevaar voor vermindering van de beste Kina-soort en van de onvermijdelijke noodzakelijkheid om maatregelen

(I) Je ne parle ici que da Cinchone Calisaya, car plusicurs antres espèces sont encore très communes.

(2) Nederl. Handals-Magazijn of Algemeen zamenvattend Woordenboek voor Handel en Nijverheid, 1843. Het zou van veel belang zijn de echte bron, nit welke dit berigt getrokken is, te kennen. 
te nemen tot het afweren van zulk een dreigend gevar? Ik heb mij in de bovenstaande uitwijdingen begeven, niet on eenen maatregel door het Nederlandsche Gouvernement in deze belangrijlke zaak genomen, te verdedigen, want hieraan was geen schijn van behoefte en de Regering zou dan ook veilig "non tali auxilio" op zulk een stelsel van mijne zijde, toepassen.

Ik wil evenmin den lof wegens het gebeurde gaan uitbazuinen, waartoe ik wel het minst van allen ben geroepen. De bloote en eenvoudige uiteenzetting van feiten is alleen mijn doel. Maar ik achtte het, tot regt verstand der zake, onverınijdelijk, en ik vleije mij dat mijne lezers dit zullen erkennen, om in haren geheelen omvang de aanleidingen en de gronden, aan wetenschap en ervaring ontleend, ja, ik zou bijna zeggen den drang, in welken de Regering was gekomen om den Kina-boom uit Zuid-Amerika naar Java te doen overbrengen, in het licht te stellen. $\mathrm{Na}$ de aangevoerde mededeelingen stel ik mij dan ook voor te mogen aannemen, dat niemand zal vragen: waarom was het noodig den Kinaboom uit Zuid-Amerika op vreemden bodem te gaan overbren. gen en op Java te kweeken?

Onderscheidene allezins bevoegde en bekwame Vaderlandsche geleerden, wier zucht tot bevordering van de belangen der wetenschappen, van het heil der menschheid en den roem van Nederland, uit eene lange loopbaan die daaraan geheel gewijd was, gebleken en boven allen lof verlieven is, heeft sedert meer dan vijf-en-twintig jaren, zoo hier als in Indië, bij het Gouvernement op de overbrengst van den Kinaboom uit Zuid-Amerika naar Java angedrongen. Het is eene billijke hulde, die men aan hunne verdiensten te dezen aanzien behoort te brengen, indien hier de namen worden genoemd van diegenen, die, in dien zin, der Hooge Regering voorstellen of adviezen aangeboden liebhen. Zij zijn Dr. C. L. 
Blume, Hoogleeraar, Directeur van 's Rijks IIerbarium (1829, $1830,1850)$, Dr. P. W. Konthals, toenmaals lid der Natuurkundige commissie van Nederlandsch Oost-Indië (1830), wijlen de Hoogleeraar C. G. C. Rennwandt (1830), Dr. G. J. Mulder, Hooglecraar aan 's Rijks Hongeschool to Utrecht (1838), de Staatsraad Dr. G. VroLık, Hooglecraar in de Kruidkunde en Verloskunde aan het Athenacum Illustre te Amsterdam (1859); Dr. F. A. W. Mrque L, Hooglecraar in de Kruidkunde en in de Geneeskunde aan dezelfde Inrigting aldaar (1846), de heer Dr. Fromberg, Agricultuur-chimist in Nederlandsch Indië (1848).

Het zal wel overbodig zijn te verzekeren, dat de opvolgende Ministers van Koloniën aan die voorstellen hunne aandacht hebben geschonlion, en dat allen, die ambtshalve daartoe waren gerocpen en ter zake licht konden geven of van raad en hulp vermogten te dienen, steeds hunne belangstelling hebben doen blijken en hunne gezindheid tevens om te pogen dit schoone doel te doen bereiken.

Eenigen van dezc gelecrden hiclden het voor waarschïnlijk, dat, na ecnige jaren, als de Kina-bosschen in Amerika zouden zijn uitgeput, op Java dic kultuur zou kunnen geslaagd zijn en daardoor schatten aan het moederland zouden worden verschaft. Anderen oordeelden, dat noch moeite, noch liosten behoorden te worden gespaard om cenen boom uit Peru naar Java over te brengen, die daar even welig als in Amerilia zon groeijen.

Men hicld nict op on de wenschelijkheid van die overbrengst te blijven betoogen. Maar de Hooge Regaring zag tegen de onkosten en de vermeende onuitvocrbaarlieid op. De wensch tot het verkrijgen van zaden dezer boomen, door tusschenkomst van de Nederlandsche Consuls in de verschillende Staten van Amerika, werd teleurgesteld, rooral sedert dat men van de moeijelijkheden orn die op hunne stations te te Valparaiso, te Lima, te Bogota, te Caracas, uit de veraf- 
gelegen bosschen en gebergten in de binnenlanden van Peru Bolivië en Nieuw Grenada te bekomen, was onderrigt geworden. Er waren zaden en planten door dezen en genen be. loofd, maar die beloften vermogten niet te worden verwezenlijkt, hoewel zij telliens op nieuw werden herhaald.

Het was op het laatst van 1850 dat de Minister van Koloniën de ervaring bekwam, dat de Fransche Regering de kultuur der Kina zou gaan beproeven in Algerië.

Uit de informatien, al dadelijk op 't vernemen van dat berigt door Zijne Excellentie ingewonnen, bleek het dat Fransche Agenten in Znid-Amerika werkelijk pogingen hadden aangewend, die ten minste in zoo ver're waren geslaagd, dat zij althans eenig zaad van den kinaboom liadden kunnen bekotnen.

In liet jaar 1851 werd ons Gouvernement van de omstandigheid onderrigt dat de Fransche Regering naar Algerië Kinazaden van Bolivië had doen overbrengen, door tusschenkomst van den Franschen Consul te Bogota ontrangen en dat de kultuur aldaar was aangevangen, door middel dier zaden.

Zulks gaf aanleiding tot het vragen van nadere inlichlingen bij hel Fransche Gouvernement. Men gaf tevens de verzekering dat de Nederlandsche Regering niet zoo zeer op het oog had om een nieuw produkt in de Overzeesche Bezittingen voor de Europesche markten aan te kweeken, als wel, om, bij de bekende uitputting der Kina-bosschen in Zuid-Amerika, die kultuur op Java te heproeven, tol heil der menschheid.

De Nederlandsche Regering had zich hierbij op het juiste standpunt gesteld. Het was toch geene zaak uitsluitend voor Nederland; - neen, het was in het belang van let geheele menschdom. Mlaar het zou toch Nederland tot eere zijn, indien 's Konings Regering mogl slagen om voor de menschheid in die schoone Oost-Indische Bezillingen orer te brengen en te hewaren, wat elders met vernieling wordt bedreigd.

In dien zin had de Fransche Regering de zaali dan ook 
opgevat; want Zij verklaarde zich genegen, om van het zaad, hetwelk door lare Agenten in Zuid-Amerika zou worden verstrekt, een gedeelte ten behoeve van liet Nederlandsche Gouvernement at te staan.

Men had in Amerika de zaden ten behoeve van Frankrijk (zoo werd later uit Frankrijk berigt) met zorg ingepakt en verzonden, en zij waren bij de aankomst in Algerië dadelijk gezaaid in bakjes met glas overdelit, onder de vereischte temperatuur; zij waren uitgeplant in overeenkomstige situatiën als welke de natuur der plant vereischte.

Het bleek later (in December 1851) dat aan de belofte, aan ons Gouvernement gedaan, geen gevolg kon worden ge. geven, daar de zaden over Marseille en niet over Parijs naar Algiers waren verzonden; tevens vernam men, dat van de jonge planten een groot deel was gestorven, terrijl later de overgeblevene aanplantingen in Algerië door een sirocco waren verwoest. Deze noodlottige omstandigheid moest de hoop van Frankrijk, om in die gewesten de nieuwe kultuur te beproeven, dan ook ten eenemale te leur stellen. Zij leverde eene reden te meer voor het Nederlandsche Gouvernement, om, indien er althans aan deze zaak een ernstig gevolg zou worden gegeven, tot doortastende maatregelen over te gaan.

Noch de beloften, noch de werkelijk gedane pogingen door de Consulaire Agenten in Zuıd-Amerika, noch de toezeggingen van partikulieren lieten zelfs de flaauwste hope op liet bekomen -van de verlangde zaden; en inderdaad moet men overtuigd zijn, dat die beambten daaraan, ook bij deu besten wil, niet konden voldoen, dewijl uit alles blijkt, dat de Commissie hun opgedragen, zonder belangrijke opofferingen en inspanningen, moeijelijk was ten uitvoer te brengen.

Men had nu genoegzame overtuiging bekomen, dat Nederland alleen door regtstreeksche pogingen bij magte zou liunnen zijn, om in die angelegene zaak werkelijk iets tot stand te brengen. 
De Mmister van Koloniën, op eigene overtuiging en op de inlichtingen van deskundigen afgaande, achtte de uitvoering dezer zaak zoo wenschelijk, dat, indien men zich op goeden grond mogt vleijen met eene lians op welslagen, de geldelijke opufferingen, die voor de Kina-overbrengst uit Zuid-Amerilia naar Java zouden worden vereischt, als nuttig aangewend zouden kunnen worden geacht.

Men was tot de overtuiging geliomen, dat hel eenige middel, om òf zaden òf planten van de Kina uil Zuid-Amerika te bekomen, alleen bestond in hel uitzenden van eenen daartoe bekwamen persoon.

Zoodanig eenen te vinden was niet gemakkelijk. Men moest in denzelven velerlei kennis, maar vooral van het botanische vak en bovendien Kina-kennis vereischen. Eene groote standvastigheid en onversaagdlıeid in gevaren en moejjelijkheden op groole reizen in vreemde werelddeelen, inaar bovenal eene goede gezondheid moesten hierbij allereerst in aanmerking komen bij hein, aan wien eene zoo gewigtige lastgering zou worden opgedragen.

Intusschen waren de ondervinding en de onldeklingen in Zuid-Anerika, door den Heer Weddell verkregen, voor de Nederlandsche Geleerden niet verloren gegaan. De roem, die daarvan uitging, maar bovenal zijne voortreffelijke geschriften, even als de basten en de gedroogde planten, door hem in Peru ingezameld, werden hier niet alleen bekend en gewaardeerd, maar kwamen mildelijk in het bezit van Nederlander's en van onze Inrigtingen voor Wetenschap. In het Museun te Parijs werden ze aan deskundigen en belangstellenden met eene loffelijke vrijgevigheid ter beschouwing of tot onderzoek afgestaan, en van die welwillendheid mogt ook de schrijver dezer medeleeling in ruime mate, bij cen verblijt in Frankrijk's hooldstad, gebruik maken.

Ik moet bijna verschooning vragen voor eene mededeeling 
hier ter plaatse, die niet op eene officiële wijze kan worden gestaafd. Zij betreft namelijk de bijzonderleid, dat eenige vau de meest beroemde Fransche Geleerden, waaronder ook de Hoogleeraren, die als Commissarissen waren benoemd gewcest van wege de Académie des Sciences, ter beoordeeling van het werk van Weddell (de Jussiev, Richard, Gauniciaud) mij destijds gezamenlijk en als hun eenparig gevoelen hebben te liennen gegeven, dat inzonderheid het Nederlandsche Gouvernement in staat zou zijn eenen grooten maatregel met goeden uitslag ten uitvoer te brengen, door de overbrengst van de Kina naar Java, alwaar zoo velerlei geschikte locale gesteldheden voor de Kina-kultuur moeten geacht worden voorhanden te zijn.

In de maand Junij 1852 deed de Minister van Koloniën aan den Koning het voorstel om een geschilit persoon naar Zuid-Amerika te zenden tot inzameling van planten en zaden en die van daar regtstreeks naar Java over te brengen.

Bij Hoogstdeszelfs Besluit van 50 Junij 1852, l. q., werd de gemelde Minister gemagtigd om de inzameling van de Kina-zaden en planten in Zuid-Amerika en de overbrengst naar Java op te dragen aan den Heer Justus $\mathbf{K}_{A R L}$ Hasskart, $_{\text {, }}$ eervol ontslagen Botanicus van 's Lands Plantentuin te Buitenzorg, met overlating aan Zijne Excellentie van alles wat tot den goeden uitslag van die zending zou worden vereischt.

De keuze van dien bekwamen man kon allezins gelukikig worden geacht. Gedurende een veeljarig verblijf op het eiland Java had de Heer Hassiarl zich kunnen gewennen aan den invloed van een tropisch klimaat. Hij had cene goede gezondheid en was van een iniddelbaren leeflijd. Hij had jaren achtereen blijken gegeven van eenen grooten lust roor wetenschappen en van veelomvattende kennis van de Flora van Java. Zijne talrijkie daarover bekend gemaakite geschriften droegen de blijken van groote naauwgezetheid, rolharding cu 
vlijt. Zijne reizen en uasporingen in Indië hadden hem eene ongemeene mate van oudervinding tot het doen van reizen, rooral in het overwinnen van de moejjelijkheden die zoo vaak uit den aard van het terrein in ees lropisch klimaat voortvloeijen, gegeven.

Van zijne vastheradenheid en beleid had nen reden te verwachten, dat hij voor deze missie bijzonder geschilit zou zijn; geen wonder derhalve, dat de Heer Minister op zijn persoon deszelfs aandacht vestigde en hem tot deze gewigtige missie aan den Koning voordroeg.

Die verwachting werd niet te leur gesteld; de uitkomst heeft geleerd dat men haar wèl had gevestigd; want het doel van de zending van den Heer HasskarL naar Zuid-Amerika is bereikt.

Een ontworpen reisplan werd gedeeltelijk vastgesteld, doch voor een groot deel aan zijn eigen beleid en oordeel overgelaten; alleen werd hem opgedragen, oin zich niet alleen te bepalen tot de inzameling van de Calisaya Kina-plant, maar zoo mogelijk ook andere Kina-soorten in te zamelen, welke hem zouden voorkomen en welke op verschillende hongten boven de oppervlakte der zee worden gevonden.

Het reisplan, voor zoo ver dit vastgesteld werd, liield iu, dat hïj van Southampton naar Chagres en verder over Panama naar Guayquil en Loxa zou reizen, van waar hij de togten naar liet binnenland zou ondernemen.

Ten einde geen tijd nutteloos te verliezen werd de voorkeur gegeven aan het reizen met stoomschepen naar Panama, boven den meur langdurigen weg om Kaap Hoorn, helgeen eell oponthoud van ten minste drie maanden zou liebben veroortaakt, alvorens de reiziger de plaatsen lion bereiken van waar hij zijne togten naar de binnenlanden van Zuid-Amerika zou kumnen aauvaugeus.

Den Aden December 1852 rerliel de Heer IIasskant 's Gra- 
venhage om zich naar Southampton te begeven van waar hij den 17 den December per stoomboot La Plala vertrok en den 1sten Januarij 1853 te St. Thomas, den 12den dier maand te Aspinwall bij Chagres en den 14den te Panama ankiwam, juist drie dagen te laat om zijne reize voorl te zetten mel de stoombool, die de havens van de Westkust van Zuid-Amerika aandoet.

Daardoor eenigzins opgehouden zette hij de reize den 25 sten daaraanvolgende voort naar Payta, om van daar naar Guayaquil te stevenen. $0 p$ het vernemen echter dat hij van daar zijne togten uit hoofde van het regensaizoen niet met vrucht zou doen, werd het reisplan veranderd en begaf hij zich naar Lima.

In het begin van Mei bevond hij zich achtereenvolgens op de eerste en op de tweede iets minder hooge Cordillières, en daarna in het lagere gedeelte van Perr. Het was daar dat hij voor hel eerst, sedert Panama, weder eenen weelderigen plantengroei zag, maar die toch op verre na niet met dien van laatstgenoemd land was te vergelijken.

Aan wolke moeijelijkheden nu zulke reizen onderhevig zijn, dit is in 't algemeen uit de berigten van natuuronderzoeker's bekend geworden maar het kan den lezer niet onbelangrijk wezen te vernemen, wat de heer Hassiorl te dien opzigte heeft ondervonden.

De wegen over het gebergte in Peru zijn slecht, veclal niet breeder dan van de ruimte voor één man te paard en aan de eene zijde zijn vaak diepe en gevaarlijlie afgronden. $0 \mathrm{~m}$ tegenkomende reizigers te passeren is niet mogelijk. Als men den kam van de tweede Cordillières voorbij is, vindt men meer trappen dan wegen. Hier moet men te roet gaan en zijne bagage door Indianen, indien men ze hier of daar mogt kunnen vinden, laten dragen. Te voet den togt roorlzellende over Vitoc naar Monohamba en Uchubamba, had lij ' genot voor het eerst Kina-hoonen in hunnen natumrlijlien 
toestand te zicn, hcewel dit nict de Calisaya-Kina was, die vooral in Zuidelijk Peru en Bolivië is te vinden. Van Monolamba terug getrokken over de tweede Cordillières, begaf hij zich naar de hoofdplaats van de provincie Zanja.

Bij Uchuhamba zag de Heer Hassiarl eenc groote hoevcellıcid cchte Calisaya-kina-boomen, doch kon hij van slechts cenige wcinige de zaden en planten verzamelen. Van dic goede soort verzamclde hij ecne grootc hoevcelheid zaden, benevens een vijftigtal planten, welke, na met veel moeite te zijn ingepakt, als ccrste bezcnding op den 28 Julij 1853 naar Lima, met bestemming naar Nedcrland, afgezonden werden. Dezc bezcnding hicld in zaden van de Calisaya, verder vier zakjes met zaden van Cinchona ovata en ecne klcinc hoeveclheid van Cinchona pubescens. In eenen hricf aan don Hecr Minister van Koloniön, onder dagteckening van 12 Augustus, zond de Heer Hasskaru later nog cen blasje met zaden van Cinchona amygdalifolia. Na ecne rcize van andcrhalve maand kwamen al deze voorwerpen gelukkig on in goeden staat te Lima aan. Zij werden aldaar door cen bevriend en nict de kultuur bckend persoon, dic tot deze medewcrling vooraf was uitgenoodigd, verzorgd, in Wardsche kisten geplant en met de zaden per stoomboot naar Panama gezonden. De kisten bleven daar, door een misverstand van den expcditcur slaan; zij ondervonden al den invloed ecner tropische hille, en toen zij almede ten gevolgc van hetzelfde noodloltige misverstand, in December 1853 te Lima terug kwamen, waren de planten allen gestorven. Hicrbij had men ook nog lici verlies van den grond, in welken de planten in die listen stonden, te betreuren; dezc toch had, indien hij hier te lande of in Inclië scheikundig ware onderzocht geworden, voor de kultunr licht litunen doen opgnan. De zaden arrivecrden inlusschen wel in Europa clì werden aan de zorgen van de Directeuren der Akademiesche Kruidtuinen en dien 
van den Hortus Botanicus te Amsterdam toevertrouwd, om daarmede overeenkomstig de inzigten des Minister's van Koloniën te lrandelen. Wij komen op die zaden later terug.

Van Uclulıamba begaf zich de reiziger meer zuidelijk, in streken, waar de tegen het Gouvernement opgestane en zich vrij verklaard hebbende bevolkingen, niet zelden zijn leven bedreigden, vermits zij in hem cen spion van liet Peruaansche Gouvernement meenden te zien. Vaak van zijne wegwijzers en dit niet zelden des nachts, geheel en al plotselijk verlaten, moest hij soms dagen lang, zonder een menschelijk wezen te zien en menigmaal van het noodigste voedsel verstoken, ronddolen, alvorens het goede spoor terug te vinden.

De meening van ten deze niet wel onderrigte personen, dat men thans nog de Kina-boomen in bosschen als 't ware gezellig groeijende, bijeen zou vinden, wordt ook nu weder op nieuws door de bevindingen des Heeren HASSKaRL weêrsproken. De naam Kina-bosschen wordt alzoo zeer ongepast. Zij zijn vaak verstrooid en zelfs in de Kina-streken somwijlen niet dan uiterst moeijelijk te vinden. Zou de tegenstrijdigheid, die in deze opgaven bij vroegere schrijver's met de tegenwoordige bestaat, ook zijn te verklaren uit de vernicling der bosschen, die in de laatste halve eeuw heeft plaats geliad?

In de provincie Carabaya aangekomen koesterde lijj de hoop om aldaar de kina-boomen nog vol vrucht en zaad te vinden, ell zulks op grond van hem gegeven berigten. Deze loop werd te leur gesteld, laar de zaden reeds waren verstrooid.

In lıet laatst van September 18303 kwam de Heer IIssliar te Cuzco, de oude Inka stad. Van daar te Sandia, de looofdplaats van lıet district van dien naam aangeliomen zijnde, waar alleen (volgens dezen reiziger) tegenwoordig de Kina voor zoo verre Peru betreft, wordt ingezameld, stelde liij zich onmiddellijli in betrekking met eenige oude en geoefende bast-verzamelaars (cascarilleros praclicos) oun door de anwijzingen van dezelven, berı- 
ten te behomen van en onderzoek te doen naar de plaatsen alwaar de Kina-boomen groeijen. Hij werd daardoor in slaal gesteld eene menigle en verschillende Kina-soorten te zien; maar hij moest levens tot zijn leedwezen ontwaren, dal hij te laat was geliomen om zaden te ver'zamelen, hebbende alle de nog aan de boomen zillende viuchten liare zaden reeds laten uitvallen. Het zij niet ongepast om te dezer plaatse te herlıalen dat hel Kina-zaad van de uiterste fijn- en ligtheid en rondom met een uiler'st dunvliezig uilbreidsel voorzien is; dat hel alzoo ligtelijk -verwaail en te loor gaal, maar ook dat hieruil de ontzaggelijke uitbreiding der Ginchonen in Zuid-Amerika mel eenige waarschijnlijkheid is af te leiden.

Er waren op dat tijdstip evenmin jonge planten van die boomsoorten te verkijgen. In Garabaya toch waren de boomen uitnemend schaarsch, zeer verstrooid en dus zeldzaam, ler* wijl de Kinabast-zoekers bijna alle de oude, dat is, de alleen zaaddragende boomen hebben uilgeroeid. Hel is daaronr vaak noodig over de groole rivier', dus over de grensscheiding van hel land der wilde Indianen te gaan, om althans eenigzins mel de hoop op goeden uilslag, deze boomen te gaan zoelien, en jonge planten die uil de zaden zijn opgekomen, hier en daar in de bosschen verstrooid te vinden.

Op deze wijze in zijue verwachtiug le leur gesteld zijnde, dat de reize in hel laatsl van 1855 zou kumnen ten einde loopen, beslool hij naar Lima terug te keeren en aldaar den droogen tijd door te brengen tot de maand April. Hij verwisselde echter die plaats, waar intusschen de gele koorts in sterken graad was uilgebroken, mel Chili, waar een koeler lilimaat lıem zijne verloren krachten el gescholite gezondlieid scheen te zullen terug geven.

Beriglen uil 's Gravenhage van het Ministerie van Kioloniën, wegens de legen Jammarịj le verwachten aankomst aan 
de Westkust van Zuid-Amerika van Zijner Majesteits Corvet, de Sumatra, onder kommando van den Kapitein-Luitenant Wippf (1), noopten hem zich voorloopig te Arequipa te vestigen, alwaar hij de tijding was wachtende, dat van Lima naar Islay zouden zijn afgezonden een twintigtal Wardsche kisten, welke hij te Lima had gekocht. Dit berigt werkelijk aangekomen zijnde, besloot hij zich intusschen weder tot op een afstand van 150 Spaansche mijlen (leguas) naar het binnenland, tot het doen van verdere nasporingen, te begeven. Hij liet te Arequipa eenen brief achter om aan den Kommandant, bij deszells arrivement, te worden bezorgd, wien hij daarbij van zijne voorgenomen reize naar de binnenlanden kennis gaf.

Met al wat tot die reize noodig was toegerust zijnde, werd die ondernomen in oostelijke rigting naar de grenzen van Bolivië.

Eene reeks van moeijelijkheden heeft zich echter hier voorgedaan, die het bekomen van Calisaya-planten bijjıa hadden onmogelijk gemaakt.

Peru en Bolivië waren tegen elkander in staat van oorlog. In het vorig jaar waren de grenzen van laatstgenoemd land geheel en al gesloten voor de Peruanen. De Heer Hass. KaRL verkeerde echter in de meening, dat het verbod om de grens te passeren was opgeheven, met die uitzondering, dat er zich slechts een kleine post bevond aan de zoogenaamde desaguaders (uitwatering), die zich aan den zuidhoek van het meer van Titicaca bevindt. Tot die gunstige verandering zou hebben aanleiding gegeven liet terugtrekkien van de Peruaansclre Legers op bevel van Echenique, ten einde Arequipa,

(1) Hicrin is later cone verandering gekomen, zijude in de plaats van lot. corvet, Sumatra, het fregat Prins Frederik der Nederlanden naar de Westkust. van Amcrika gezoudcn. 
waar de opstandelingen zich hadden geschaard onder de vanen van Castilla, ten onder te brengen.

Bolivië was vooral het land naar hetwelk hij zijne blikken rigtte, omdat, naar hetgene men liem, te regt of te onregte lıad berigt, aldaar de Kina-boomen niet zoo zeer verspreid, maar op sommige plaatsen, die men manchas noemt, in groote hoeveetheid voorkomen, terwijl de boomen daar in liet algemeen, veel liooger opgroeijen. Kron het den reiziger dus gelukken in de dieper gelegen districten van Bolivië door te dringen, dan was de lians om planten en zaden te bekomen, niet onvoordeelig, vooral daar de Calisaya in Bolivië de Kinla-bast bij uitnemendheid is, welke aldaar wordt ingezameld.

De grenzen van Bolivië werden spoedig bereikt. Men bevond zich weldra nabij La Paz, niet ver van het Boliviaansche sneeuw-gebergte te Sutchis, een Boliviaansclı grensdorp, waar men echter vernam dat de oorlogsmaatregel, die liet passeren der grens verbood, nog niet was opgelıeven, gelijk men dit den Heer Hassiarl verkeerdelijk lıad berigl.

Men moest dus besluiten zicl weder op het Peruaansche gebied terug te trekken, en hieraan werd dan ook greedelijk gevolg gegeven, met liet plan om zich langs de Boliviaanshe grenzen naar liet in oostelijke rigting gelegen Sandia te begeven. Met wellie moeite en bezwaren echter die togt vergezeld ging, kan men zich naauwelijks voorstellen, zonder zijne eigene mededeelingen in haar geheel voor te dragen, doch waarvan wij ons te dezer plaatse, om wijdloopigheid te rermijrlen, moeten onthouden.

Aan de grensplaatsen van Peru vindt men reeltijds verstrooide Bolivianen, dat meestal cascarilleros zijn. Voor dezen was dan ook de grens niet afgesloten, zoo als dit voor Peruanen liet geval was. Zij drijven daar lımnen lıandel, heb. ben lıunne woningen en lıunne familiën iı Bolivië. Zij voeren allerlei voorwerpen of produkten in en uil, en waren nict 
alleen genegen om deu Heer IIAsskarc te dienen, maar beLoonden hem inderdaad alle wenschelijke hulp, zoodanig, dat hem al spoedig door dezen levende planten, door genen zaden uit Bolivië, gelijk van zelve spreekt tegen eene billijke vergoeding, werden toegezegd. In afwachling nu hiervan begaf hij ziclı van de eene grensplaats naar de andere, ber'eikte eindelijk hel reeds bovengenoemde Sandia, alwaar hij beslool zijn hoofdkwarlier te vestigen, en waar men de le leveren voorwerpen zou aanbrengen, opdat hij die na hunne aankomst zou verpakken, waartoe alles te dier plaatse in tijds moest worden aangebragt. Hij verbond daaraan tevens het voorne. men om zelf de dieper landwaarls in gelegene streken te gaan bezoeken, om zoo veel als mogelijk was naa de Calisaya-kina uil te zien.

Intussclien werd de overeenkomst met Bolivianen, om planten en vruchten of zaden van Kina-boomen, waarloe nien aan die lieden leeflogt, geestrijke dranken enz. had gegeven om hunne muildieren te beladen en tot ruil te doen dienen, grootendeels verwezenlijkt en mogt liij inderdaad hierdoor slagen. Een der Bolivianen was namelijk, terwijl de Heer HassKARL zich van Sandia oostwaarts had begeven, met een zeer aanzienlijk getal levende planten aldaar aangekomen. Dit berigt ontvangen liebbende spoedde hij zich naar Sandia terug om alles in veiligheid te brengen, opdal de planten niel door lucht en hilte zouden lijden. Te dier plaatse aangeliomen vond hij werkelijli omtrent 400 Calisaya-planten, ecliter niet allen van de sterkte zoo als men was overeengeliomen. De aanvoerder had eene zeer moeijelijke reize moeten maken om met dien kostbaren last te Sandia te arriveren.

Wij treden lier niet in de vermelding van de onbesclurijfelijke moeijelijliheden en gevaren, welke de Heer HasskarL met die kostbare lading had te doorworstelen, alvorens hij 
eenen weg van 150 leguas (Spaansche mijlen) had afgelegd, on die voorwerpen in behouden staat tot nabij de plaatse der inscheping te brengen. Er werden bij herhaling de noodige middelen beraamd en in 't werk gesteld om den wensch te zien verwezenlijken wegens het bekomen van toegezegde zaden, die hij echter niet heeft mogen erlangen. De persoon, die de bezorging had op zich genomen en hem bij zijue ankomst te Sandia zou volgen naar Arequipa en Islay, waartoe een voldoend reisgeld was verstrekt, is niet gekomen. Ilet belang dat men in het behoud der levende planten moest stellen, maakte het tevens raadzaam niet te vertoeven.

Bij het verpakken van die planten was op onderscheidene omstandigheden te letten: vooreerst moesten de planten vochtig genoeg blijven, om, zonder uit te droogen, de liust te kunnen bereiken, niettegenstaande de sterk uitdroogende winden en de bijna loodregt neêrvallende zonnestralen. Vooral tegen deze laatste was het, dat zij moesten beschermd worden om de groote warmte gedurende den dag te weren; terwijl daarentegen des nachts en des avonds de koude, welke op die hoogten vrï sterk is, gebiedend vorderde om die kostbare voorwerpen, tegen het tegenovergestelde uiterste te beschermen. Juist in de maanden Junij tot Augustus is op die hooge plateaux het water (en dit vooral des nachts) tot ijs hevrozen. Indien het doel des onvermoeiden reizigers tevens geweest ware de planten in aarde geplant over te brengen, zoo zou het gewigt, en het daardoor noodwendig vermeerderde getal lastdieren groote hindernissen hebben opgeleverd. De planten zelve, maar bovenal hare wortels, zouden door het onophoudelijk schoklien der dieren stellig zijn beschadigd.

Het was ook nog uit andere oogpunten nuttig, om de planten derwijze te verzorgen, dat zijj niet zouden hebben 
te lijden. In aanmerking genomen toch, dat groote planten moejjelijli tegen de meer gemelde uitwendige schadelijke invloeden waren te beveiligen, moest men de stammetjes zeer kort insnoeijen en ze met de wortels in vochtig mos pak. ken. Ieder paksel werd gewikkeld in de schil van pisangstammen, daarin vastgebonden en met zaklinnen tot kleine pakjes of baaltjes gemaakt, die wel iets op wolbalen geleken, gelijk waarin goederen worden vervoerd op dusgenaamde slumas uit de binnenlanden naar de kusten. De tot dit verpakken benoodigde Pisang-stammen, moesten op de schouders van Indianen uit de laag liggende landen worden opgehaald; het mos, dat evenmin te Sandia groeide, moest uit de bergstreken worden verkiregen; al hetwelk, bij de groote onhandigheid en luiheid der Indianen, veel moeite, tijd en geld kostte.

Maar de grootste moeite veroorzaakte het verkirijgen van het noodige touwwerk. Er werden vier personen gezonden naar de lagere en boschrijke streken om den bast van eenen boom, door de inlanders panoho genoemd, te verzamelen en te bewerken om voor bindwerk te kunnen dienen. Sterkere touwen moesten dienen tot het vastbinden der pakien op de lastdieren. Deze werden van Gruzero outboden en hierin vond den Heer Hassikarl welwillende medewerling.

Het zamenbrengen van de noodige muildieren roor liet transport, was in deze eenzame en afgelegen plaats geene geringe zaak. Het waren zwakke dieren, die niet het lialve gewigt konden dragen, hetwelk de inuildieren van Arequipa verinogiten te torschen.

$\mathrm{Na}$ hel overwinnen van een legio van zwarigheden van allerlei aard, te vele en te verschillende, om alle hier te liunnen worden opgesonud, werd eindelijk op den Ssten Junij de expeditie van Sandia af in beweging gesteld. 
Intusschen scheen liet als of er aan de bezwaren geen einde zou komen. De dieren werden zooveel als mogelijk was ge. dreven; het was toch in het belang der planten noodig, de reize zoo veel mogelijk te bekorten. Van des morgens vroeg tol 's avonds laat reisde men bijna onverpoosd voort, om hel hooge land met zịjne sterke afwisselingen van temperatuur over dag en bij naclıt, achter den rug te hebben en van den grooten weg af te komen, opdat de cavalcade aan de troepenmassas, die alle transporten als contrabande des vijands in beslag namen, geen opzien zou baren en de planten, die, uit dien hoofde, door menig gevaar werden bedreigd, weldra in veiligheid mogten zijn.

Intusschen vernam men, te Azangora geliomen zijnde, dat er hoegenaamd geen lastdieren waren te verkrijgen, daar deze allen door de opstandelingen tot de partij van Castilla behoorende, waren gerequireerd, om de van Bolivia gearriveerde geweren enz. naar Cuzco te brengen; terwijl andere drijvers de wijk hadden genomen naar het gebergte, ten einde niet te worden gedwongen eene gelijlie dienst te doen voor liet corps van den Generaal Roman, die van Puno naar Cuzco onder weg was.

Het blijkt, dat de spanning der twee republieken tegen elkander en de onrustige toestand van de oorlogvoerende partijen in Peru zelve, de expeditie van den onvermoeiden en onverschrokken reiziger in groote meeijelijkheden gebragt en bijna de gewenschte uitkonst heeft doen missen.

Wij volgen hem ook hier niet in de optelling van al die tegenspoeden en nemen slechts over, dat lïj, afgerekend vij؟ dagen opontlioud, door het ontmoeten ran lirijgsvolli enz. met versnelde marschen in ééne week de reis van Sandia naar Arequipa heeft volbragt. 
'Te Arequipa vond de Heer II Asskarl een schrijven van den Kapitein ter zee, den Heer vas Brasm Houglaeest, Kommandant van Zijner Majesteits Fregat Prins Frederili der Nederlanden, welk fregat slechts weinige dagen vroeger ter kust was anngekomen. De Kommandant schreef daarin, dat hij tot zijne overbrengst en die der kina-planten van daar naar Oost-Indië was gearriveerd en dat zijne order's luidden, om, zoo hij den Heer Hasskarl te Islay niet aantrof, dadelijk naar Callao te vertrekken en hem aldaar op te wachten. Indien het fregat acht dagen later te Islay ware aangeliomen, dan hadden de planten dadelijk kunnen worden ingescheept. Het nog niel aangekomen zijn van de uit Lima over Iquique verzonden planten-kisten gaf hem aanleiding om den Kommandant te verzoeken, om hem te Islay te komen afhalen, ten einde van daar naar Iquique te stevenen om de kisten in ontvang te nemen, als wanneer hij tot de reize naar Java gereed zou zijn. Hij rekende den 26 Julij te Islay te zullen zijn en hoopte Zijner Majesteits fregat denzelfden dag daar te zullen vinden; hij ging daarbij uit van de onderstelling, die later bleek eene dwaling te ziju (ontleend aan Fitz-Roy's Beschrijving van de Zeevaart op de Westliust van Zuid-Amerika), dat el namelijk aldaar in Julij en Augustus noordelijke winden zouden heerschen.

Alvorens Arequipa te verlaten, werden aldaar door HAss. KARL bij een bevriend persoon de noodige order's gelaten, om, ingeval de verwachte Calisaya-zaden zouden annkomen, deze dadelijk naar Islay te zenden, of, ingeval de Heer HassKARL reeds mogt zijn vertrokken, die zaden in kleine listjes gepakt, over Panama naar Amsterdam te expediëren.

Nieuwe zwarigheden, als scheen hel dat er nog niet genoeg waren geweest om den moedigen reiziger' als 't ware bij 't eind der missie te beproeven. Islay was door de parlij van 
Ecirenique, lijdens de twisten in dit door burgeroorlog verscheurde land, hernomen. Er werd van daar een anval tot verovering op Arequipa voorlbereid. Maar hiertoe ontbraken haar de middelen van transport. De Heer Hasskarc had veel lastdieren noodig om zijne pakkaadjen over te brengen. Om die te verkirijgen bestond geenerlei uitzigl. Men vreesde, gelijk later bleek, niet te onregte, dat de dieren zonden worden in beslag genomen. De winst die de expeditie opleverde, was niet evenredig aan het rerlies helwelk de drijvers vreesden dat hun deel zou worden. De partij van Gss. tiLla, die de overhand in Arequipa had, stond bovendien de afreize naar Islay niet toe, en liet eene gevaar liwam bij het andere. Eindelijk, toen men des noods schadevergoeding voor het mogelijk verlies der dieren verzekerde en toen personen van invloed te Arequipa zich voor den Heer HassraRL in de bres stelden, werd hem de verlangde aftogt loegestaan. Op de reize naar Islay viel wel niets belangrijks voor; daar echter werden de dieren dadelijk tot militaire transporten geprest. Te Islay waren de Wardsche kisten gearriveerd, maar liel fregat scheen eerst na 14 dagen te zullen komen. Dit gaf hem aanleiding om met een aldaar liggend vaartuig, dat met ballast naar Callao zou vertrekken, alwaar de Prins Frederik der Nederlanden gestationneerd was, de reize derwaarts aan te nemen. Drie dagen later was men reeds ter reede van de laatslgenoemde plaats aangekomen. $0_{p}$ dien overtogt ontpakte de Heer Hassisarl zijne Kina-planten, hetgeen zonder stoornis kon geschieden. Hij mogl zich daarbij allezins over haren gunstigen toestand verheugen, daar zij, na gedurende meer dan vier weken van lucht en licht te zijn afgesloten geweest, bij het doorsnijdén der stammen, bijna zonder vilzondering, eene frisclie kleur vertoonden. Hij plantte ze nu dadelijk in de doelmalig ingerigte listen. 
Nen arriveerde den $7^{\text {den }}$ Augustus, des avonds zeer laat te Callao. De Ilecr Hassianu gaf den $8^{\text {sten }}$ in den vroegen morgen, dadelijk van zijne aankomst kennis aan den Kommandant van het op die reede liggende fregat. Den volgenden dag werden de planten-kisten mel de verdere zaken van den Heer Hassiarl aan boord van Zijner Majesteits Fregat overgebragt en gedeeltelijk op het achterdek, gedeeltelijk in en nevens de barkas geplaatst. Eerst den $21^{\text {sten }}$ Augustus was het fregat tot de afreize gereed, gedurende welken tij hij zich te Lima ophield.

Van Callao nam de Kommandant zijne directie over de Sandwichs-eilanden, en na een oponthoud van 10 dagen, werd de reize voortgezet over de Mariannes- of Ladroneneilanden naar de Chinesche zee, van waar men stevende naar Java.

Zoodra men de koelere luchtstreek van de westkust van Zuid-Amerika had verlaten, begon de warmte van dag tot dag grooter to worden, zoodat, voor 't grootste gedeelte van den dag, de thermometer van Farrenireit in de scliaduw tusschen 80 en $86^{\circ}$ teekende. Den Heer Hassirarl gaf dil te regt bezorgdheid over zijne planten, die, naar zijne waarnemingen in hare natuurlijke standplaatsen, gewoonlijk eene temperatuur niet boven de $60^{\circ}$ Fahr., maar meestal beneden de $50^{\circ}$ Fahr. en enkele malen nabij het vriespunt hebben. De bedoelde voorwerpen hadden in deze hitte veel te lijden, 't geen vooral daarom schadelijk moest zijn, vermits zij al ten naastenbij (met inbegrip van het vervocr in Bolivié zelve) eene landreize van zes weken gemaakt hadden. Beschaduwen met tenten enz. kon wel de heete zonnestralen afweren, maar de litte was zoo sterk, dat de glazen der kisten bijna dagelijks inwendig waren beslagen. De kisten werden geopend, ten einde den schimmel, 
die zich ontwikliclde weg te nemen en men vond het gepast, on dit dagelijlis te herhalen. De warme luchtstreek werkte blijkbaar nadeelig op de planten. De schimmel hernieuwde zich gedurig en moest dus telkens worden weggenomen. In het begin van de reize en later na de afreize van de Sandwicliseeilanden, werden alle kisten nog eens nagezien of $\mathrm{z} \ddot{\mathrm{y} j}$ water noodig hadden, en werden dic welke daar beloefte aan hadden, daarvan (echter zeer spaarzaam) voorzien, zoodat in 't geheel, in beide keeren, nog geen 5 putsen zoet water werden aangewend.

Slechts de sterkere planten begonnen voor een groot gedeelte uit te botten; de anderen toonden daarvan wel niels; maar de stammen bleven duidelijk nog leven. Eenige daarvan begonnen gedurende de reize ook nog uit den wortel uit te schieten, terwijl van de zwakkere planten het gedeelte, hetwelk ziclı boven den grond bevond, scheen tc zullen afsterven, doch het was blijkbaar te verwachten dat deze later zouden uitschieten, Het werd cvenwel niet raadzaam geacht on dic voorwerpen, door cen ontijdig onderzoek of losmaken van de aarde om de wortels, in gevaar te brengen.

Zijne Excellentie de Gouverneur-Generaal van Nederlandsch Indic̈ berigtte, onder dagleekening van 22 December $185 \%$, aan Zijne Excellentie den Heer Minister van Koloniën, dat de Heer Ilssskarl den $13^{\text {den }}$ dier maand te Batavia was aangekomen, ecn-en-twintig kisten met kina-planten aaubrengende.

Uit dit verslag van den Landvoogd blijkt tevens, dat het langer oponthoud van het fregat te Callao was reroorzaakt door de moeijelijkheid om levensmiddelen en brandstoffen te beliomen; alverder, dat deze bodem op cenen afstand van 110 mijlen van de Philippijnsche eilanden, door een zware orkaan was beloopen en veel schade-had bekomen. Het fregat liwam 
op $\breve{3}$ December te Macassar aan. Daar nu in dit jaargetijde eene langdurige reize naar Batavia tegen het belang der planten was te achten, was de Heer Hasskant met zijne verzameling overgegaan op Zijner Majesteits te Macassar gestationnecrd stoomschip Gedeh, waarmede hịj, gelijk hierboven gemeld is, den $15^{\text {den }}$ December le Batavia arriveerde.

Er zijn onmiddellijk door den Gouverneur-Generaal maatregelen genomen, om de kisten met planten naar Builenzorg en van daar verder naar het hooger gelegen Tjipannas over te doen brengen, waarin echter, wegens het onstuimige weder, eene vertraging van een paar dagen was gekomen.

De Heer HasskarL werd na zijne aankomst met de kultuur der Kina op Java belast.

Wij hebben boven reeds melding gemaalit van zaden door den Heer Hasskanc naar Nederland gezonden. De gevolgen van die zendingen zịn als een direct uitvloeisel van de door dien Heer uitgevoerde commissie te beschouwen en wat daarvan te vermelden valt, vindt dus hier voegzaam eene plaats.

Bï het Ministerie van Koloniën zịn achtereenvolgens uit Amerika, vooral van dien kruidkundige, ontvangen zaden van verschillende soorten van de hieronder genoemde Cinchonen.

1o. Cinchona Condaminea Lamb. S lancifolia Wedd. (C. lancifolia Mutis) in Nieuw-Grenada ingezameld en aldaar door den bekenden reiziger Karstes an Zr. Ms. Consul-Generaal te Garacas, den Heer van Lansberge, aangeboden. Van deze zaden zijn in den Nkademic-tuin te Leiden eenige planten opgelomen.

Van den Heer HassrarL werden ontvangen:

2o. Cinchona amygdalifolia Wedd., met de overlandpost naar Java verzonden. 
5o. Cinchona Cialisaya Wedl. uil de vallei van Sandia, provincie Carabaya in Peru. Van deze soort is ecne hoeveelheid zaad dadelijk bij de ontvangst mede per overlandpost naar Java gezonden. De andere hoeveelheid is in enkele botanische tuinen gezaaid.

4?. Cinchona Calisaya Wedd. var. $\beta$ Josephinae. Alhier gezaaid, doch in den tuin te Leiden slecht opgekomen.

$5^{\circ}$. Cinchona pubescens (Cascarilla crispilla grande). In de botanische tuinen gezaaid.

$6^{\circ}$. Cinchona ovata R. et P. (Cascarilla crispilla rhiqua of chiqua). Er werd bij berigt, dat deze, even als no. 4, als heesters groeijen in de nabijheid van Hohubamba (Peru) tusschen 5.6000 Par. voeten op vrij zonnige hellingen, terwijl no. 5 groeit op 6-7000 voeten, in hooge bosschen en ook wel op hellingen, in eenen humus-rijken grond, die met meer of minder groote stukken glimmerschiefer was verınengd; welke omstandigheden bij de tot kieming legging der zaden en kweeking der planten werden in aanmerking genomen.

De ontvangen zaden (voor zoo zerre zij niet onmiddellijk zijn verzonden naar Java) werden dadelijk bij de aankomst door Zijne Excellentie den Heer Minister van Koloniën aan Directeuren van de botanische tuinen der Hoogescholen en van den Hortus Botanicus te Amsterdain gezonden, om ze te doen kiemen ell verder aan te kweeken.

Het zal wel geheel onnoodig zijn te vermelden, dat deze genoemde bestuurder's van het belang der zaak doordrongen, zich alle mogelijke moeite hebben gegeven, om dis voorwerpen te doen beantwoorden aall het doel des Ministers. In het begin van 1854 en enliele zaden reeds op 't laatsl. van 1853 gezaaid zijnde, verkreeg Zijne Excellentie van wege de botanisclie tuinen, reeds liorten tijd na de uitzaaijing, gunstige berigten wegens de kieming.

Van het andere deel der zaden, hetwelk ter nitzaaijing 
door den Minister per overland-mail naar Java was gezonden, zijn van den Gouverneur-Generaal gunstige berigten bekomen, (zie lager) welke laatste gunstige omstandigheid den Minister aanleiding gaf, om de bij de Nederlandsche tuinen nog aanwezige hoevechlheden zaden op te vragen en met de overlandmail insgelijks naar Oost-Indië te verzenden.

Men zal ger'cedelijk inzien, dat de Itecr Minister, door de zaak op alle mogelijlic wijze te beproeven en te bevorderen, geen ander doel heeft gehad, dan om zich van het wèlslagen der voorgenomen overbrengst, immers zooveel mogelijk was, te verzekiren.

De Kina-planten, in de tuinen gekweelit, vorderden intusschen derwijze in hare ontwikkeling, dat men nog in 1854 verzendingen kon doen naar Java.

Deze hadden dan ook werkelijk plaats, en werden uit de tuinen van Leiden, Utrecht en Amsterdam de hierna te melden expeditiën gedaan:

1.. Uit Leiden, planten van Cinchona Calisaya, per NederLand, Gezagvoerder P. Huidekoper.

20. Uit Utrecht, planten van Cinchona ovata, per Hexdrika, Gezagvoerder Admiraal; welke bodem, gelijk bekend is, op 6 December jl. voor de Vaderlandsche liust is vergaan.

50. Uil Amsterdam, planten van Cinchona calisaya en Cinchona pubescens, per ZaAnstroon.

Omtrent de bezending no. 1 zijn vrij gunstige berigten uit Oost-Indië ontvangen. Omtrent de bezending no. 5, worden die nog verwacht.

Er blijven in de Botanische tuinen nog voorwerpen ter verzending naar Java over, wartoe ecrlang kan worden overgegaan.

Kon er bij lıct outvangen van de zaden door den Ileer 
Hasskanz onder den naam Cinchona Calisaya Wedd. gezonden, kwestie riju oul de juishleid van dic soortsbenaming te betwijfelen? Ili meende toen reeds, neen. De Hooge Regering laad naar Peru gezonden eenen door en door bekwamen en door eene lange ondervinding in liet onderzoeken der natuur ervaren geworden kruidlkundige, wiens talrijke geschriften getuigen van strenge naauwgezetheid en eene tot in de minste bijzonderheden voorlgezelte scrupuleuse naauwlieurigheid. Zijne liefde tot waarheid is boven den gewonen lof verheven. Zijne speciale kennis ter zake moest bovendien tegen elke mistasting vrïwwaren. Met zulke waarborgen voor mijne overtuiging meende ili a priori te kunnen voorzien, dat uit de kostbare zaken, welke de Regering aan de Botanische tuinen wel lieeft willen loevertrouwen, indien zij mogten kiemen, geene audere planten zouden te voorschijn komen dan de Calisaya-Kina-plant, onder welker naam ik die zaden had ontrangen.

De uitkomst heeft die verwachting niet te leur gesteld. De Kina-planten hier ontwikleld, zijn Calisaya-planteı. Een streng onderzoek heeft mij dit zóó zeker bewezen, als de wetenschap dit slechts mogelijk maakt.

Ik ben verpligt die wetenschappelijke gronden op to geven, oundat de zaak van grool gewigh is.

Wij bezitten van de meeste Kina-soorten goede besclirijvingen en afbeeldingen door Weddell. De Calisaya-Kina is boven alle de andere soorten (zij zijn $20 \mathrm{~m}$ getal) bijzonder karakteristiek. Die karakters, de uitwend:ge zoowel, als die, wellie aan de structuur (vooral van de bladen) ontleend worden, zịn bovendien door Wedoel ntel eene bijzondere uitvoerigheid en naauwkeurigheid opgegeven en afgebeeld. Ik heb die alle nagegaan en in onze planten alle, zonder onderscheid te vinden, aangetrolfen. 
Ik noem daaronder den bladvorn, die inderdaad van de gedaante der bladen in al de andere Cinehonen afwijkt. Iet blad is langwerpig of laneetvormig-eirond, aan de punt stomp, van onder smaller, zelden aan de beide einden in eenen selerpen hoek niteenloopende (puntig), onbehaard, blinkende, of (van onder vooral) nan de aders zeer fijn en zaelit behaard, in de oksels der aders voorzien met eigenaardige holten. De lengte der bladen, die naar den volwassen boom is opgegeven te zijn 8-15 Ned. duimen op eene breedte van 3-6 duimen, bedraagt in onze grootste bladen 13 op 5 breedte. Zaeht op het aanvoelen, zijn zij op de oppervlakte, gelijk boven is gezegd, onbehaard, uitgenomen dat zij hier en daar alleen staande, kromme, lange, stijve en over de bladvlakte neêrliggende borstelige haren hebben, die meestal later afvallen. Dit geldt ook van de lange haren aan den rand der bladen en van korte, fijne, digt overeenliggende haren (boven bedoeld) op de dusgenaamde ader's en hare takverdeelingen aan de ondervlakte van het blad. Hoogst merkwarrdig is de ondervlakte van het blad. Reeds met het bloote oog ziet men darrop eenen geheel eigenaardigen glans, en door een vergrootglas gezien, wordt die nog veel sterker. Maar heerlijk sehoon doet zieh dat versehijnsel voor, wanneer men in de rigting van de bladvlakte met een seherp mes eene zeer dunne laag afsnijdt en die cloor middel van een mieroseoop vergroot, aansehoumt. Het heeft een min of meer robbelig aanzien of biedt eene oppervlakte aan, die bestaat uit kleine, meer of min bolronde of kegelvormige an elkander grenzende blansjes. De zoo even vermelde haren bestaan uit onderseleidene met elkander verbonden eelletjes, en deze zijn hier en daar gestippeld. De eellen van het opperhuidsvlies hebben eenen eigenaardigen bogtigen vorm, gelijk dit in meerdere planten van hoogeren rang plaats heeft. De kleur der bladen is van boven donker, van onder liehter groen, of (zoo als WEDDELL zegt) smaragdgroen. Wat aaugant de eigenaardige boven reeds besproken holten, die in de hoeken of oksels van de aders voorkomeu, deze zijn hier namelijk zeer sterk ontwikkeld, veel meer dan in eenige andere soort van liet geslaeht Cinchona. Niet in alle bladen zijn die 'holten door eene verhevenheid an de bovenzijde even duidelijk zigtbaar, maar in de meesten zijn zij toeh aanwezig. Men vindt dan'van eene voortreffelijke af beelding bij WedDeli (Pl. I. 18.) De jeugdige bladrorm wijkt van den volwassen vorm meer of min af. De bladsteel, die sleehts 0,01 lang is, heeft eene groene, zelden eene roode kleur even als de middemrib. De aders zijn ran boven bleekgroen, van onder nu en dan lieht rood. De stoppeltjes, d. i. de blaadjes, relke het jonge bladpar ingesloten houden en later afrallen, zijn lingwerpig, rond ain de punt, van buiten onbehnard en aim de 
binncuzijde met kliertjes bezet (dit vooral nan de basis) en aun de overige oppervlakte zcer zacht behaard.

Onder dagteekening van 21 October 1854 heeft de Gouverneur-Generaal aan den Minister van Koloniën berigt, dat een groot gedeelte der te Tjibodas anwezige Kina-planten, uit de van hier door het Ministerie overgezonden zaden verkregen, dien groei hadden bereikt, dat zij in eenen geregelden tuin konden worden uitgeplant.

De latere berigten omtrent die uitplanting hebben wel niet het behoud doen kennen van het meerendeel der plantjes, welke te Tjibodas uit zaden waren opgekomen, maar dit was ook niet te verwachten. Dit heeft nimmer en nergens plaats bij uitplantingen; de ondervinding toch leert doorgaans, dat niet altijd alle planten uit een zaaisel ontstaan, opgroeijen en behouden blijven.

De uitkomsten nu van de Kina-kultuur, onder de leiding en zorgen van den Heer Teysmans, zoowel die, welke van de zaden van den Heer Hassisarl zijn bekomen, als van de planten uit de tuinen van Leiden en Ainsterdam bij vorige gelegenheden naar Java verzonden, komen, blijkens het verslag van den Hortulanus van Buitenzorg, in dato 15 December 1854, in afschrift gevoegd bij het liabinetschrijven van den Gouverneur-Generaal van Neêrlandsch Indië, in dato 22 December 1854, No. 224, Bijl. 3, aan den Minister van Kolonien, hierop neder:

In 't begin van de maand November 1854 lıad zich de Heer Teysmans naar Tjipannas in liet gebergte begeven om de voor de aanplanting der aanwezige Kina-plantjes benoodigde gronden in gereedheid te doen brengen.

Het terrein, wat daarvoor door den heer Teysuans geschilit werd geaclit, was toen nog met zwaar geboomte bezet. Dit echter 
daartoe later geheel in gereedheid zijnde gebragt, zijn de anplantingen onmiddellijk ingerigt. Zij hebben plaals gehad ongeveer $\frac{1}{2}$ paal boven den tuin te Tjibodas, welligt $5-400$ voeten hooger' dan deze plaats en hijgevolg ongeveer 4600-4700 voeten boven de opperrlakte der zee. De gronden zijn zeer rijk aan humus met eenen poreusen velachtig rooden ondergrond, waarin boomen van kolossale grootte, meestal 150 voeten hoog en 4 à 6 voeten in doorsnede, weelderig lierden, die nu echter allen zijn omgekapt. Het terrein ligt ten noord-ivesten van de diepe ravijn Tjibodas, aan de helling ran het Gedeh-gebergte, en biedt zoowel hooger op als meer beneden, even goede gronden an om deze kultuur verder uil te breiden, mils de zware bosschen vooral geveld worden. Het klimat is er hel gansche jaar door, maar vooral in den regentijd, zeer vochlig en de vegetatie bij afwisseling in de wollien gehuld.

De Kina-planten zijn geregeld en in verband op 20 voeten onderlingen afstand uitgeplant, zoodat daartoe een terrein van ruim $\frac{3}{4}$ bouws gebezigd is.

Er bevinden zich nu in die hultuur de Cinchona-soorten, welke men aan den Heer HassKarL verschuldigd is, bovenal de Calisaya.

Hierbij moeten nu nog liomen de Calisaya-planten uit Peru, direct door den Heer Hasskanc aangebragt, - de bezendingen van den Heer Wrulink te Amsterdam, de planten verzonden en nog te verzenden uit de Akademie-tuinen en dien van Amsterdam, en de planten die uit Nederland op verschillende lijjlen zijn gezonden naar Oost-Indië; voorts die, welke uit de zaden aldaar nog kumnen opkomen, waardoor men lian aannemen, dat de aanplantingen nu reeds gekomen of dit in korten lijd zullen zijn in veel grootcren getale, dan tot het slagen der kultuur vereisclıt werd.

Hoezeer wij innigg overluigh zijn, dal aan de planten door den Heer Tersuann alle wenschelijlie zorg is besteed, zoo is liel 
wel niet mogelijk, dat de kultuur door icmand beter zal kunnen worden behartigd, dan door hem, die ontelbare malen zijn leven in de waagschaal gesteld zag, in de landen van waar hij de levende boomen naar Java overbragt. De opmerlingen omtrent liunnen groei en de natunrlijke gesteldheid der plaatsen, waar men ze aantreft, liunnen door denzelven op Java bij de kultıur worden in praktijk gebragt. Talrijke bijzonderheden, die ook den meest opmerkzamen waarnemer, die de oorspronkelijke groeiplaatsen niet bezocht heeft, kunnen ontgaan, zijn door de ondervinding van den Heer HassKARL hier in toepassing te brengen. Het veeljarig vroeger verblijf van dien natuur-onderzoeker op Java, zijne bekendheid met de topographische gesteldheid van liet eiland, met de hoogten, de plateaux, de bergen, hunne hellingen, de gesteldheid der gronden en de vergulijking van deze met die. waarin liij de Kina zag groeijen, - die rịke schat van kemnis en ondervinding, meenen wij, kan van de reeds zoo goed geslaagde pogingen eene goede uilkomst doen verwachten.

De Heer Hassiarl heeft voor zijne moeijelijke en wel geslaagde pogingen, de hooge goedkeuring van Zijne Majesteit den Koning mogen verwerven. Dit blijkt uit zijne benoeming tot Ridder der Orde van den Nederlandsclıen Leeuw, waartoe hij door den Minister van Koloniën aan den Koning werd roorgedragen.

Aan de geleerde inannen, die de opmerkzaamheid der Hooge Regering op deze zaak hadden gevestigd, is mede op roorstel van Z. E. den Heer Minister, bij Kabinel-schrijven, Zijner Majesteits tevredenheid uilgedrulit, over lıet deel hetwelli zij aan die zaak hadden genomen.

Bij al hetgeen reeds ten aanzien van dezen grooten maatregel door liet Gouvernement genomen en van den directen Kina-invoer uil Zuid-Amerilia op Java door den licer H.sss- 
KAHL, is medegedeeld, achten wij liet evenwel niet ongepast, om ook voor te dragen, wat van tijd tot tijd van wege de Botanische tuinen en eenen enkelen particulier, den Heer J. A. Wrulink WZN., in Nederland, ten belıove dezer gewigtige zaak met goed gevolg is gedaan; hoezcer dic pogingen allecn en op zich zelve liet groote loel der invocring, naar ons oordeel, niet zouden hebben doen bereiken.

Uit den kruidtuin te Amsterdam waren door den Hooglecraar Mrquec onderscheidene Kina-planten naar Java gezonden. Zeer gunstig waren, onder anderen, de resultaten van de uitzending van eenen Kina-boom uit dien tuin in 1847 naar Java gezonden, onder den naam van Cincliona alba, die, na te Buitenzorg to hebben gebloeid, aldaar genocmd is Cascarilla Muzonensis Wedd. of Cinchona Muzonensis Gaud. (1).

De Heer Tersuans heeft zich met de behandeling, ook van dic plant, welke een struikgewas is, ijverig bezig gehouden en had al spoedig, door vermeerdering, meer dan 100 planten daarvan verkregen.

Ter bevordering van het scheikundig onderzoek dezer Kinasoort, werden eenige takjes door den Heer Teysuane gezonden aan den Heer Rost van Tonningen, destijds apotheker bij 's lands Laboratorium tc Batavia; cen onderzoek, dat echter',

(1) Aangenomen dat de bepaling der soort door de Botanici van Buitenzorg juist is, waaromtrent wij ons geen oordcel aanmatigen, sloegen wij op het Philos. Mag. van 1828, p. 132. of daar ook eenig nader berigt omtrent dic plant voorkomt. Fr staat niets bij opgegeven, dan dat zij grocit in de nabijhcid dcr Sadelluzo. WEDDELL heeft haar welligt niet gekend door eigen anselouwing, en wij vinden in zijn gesehrift gecne nadere mededeclingen over dezelve. De verzending van dien boom uit den tuin te Amsterdam wordt dus tot anvulling van de onvolledige bekende geschiedenis dezer soort nog belangrijker. Wij vernamen dezer dagen uit zeer reecnte berigten, dat $C$. Mruzonensis in den tuin van Weltevreden welig tiert. Dit geeft ook ten anuzien van andere scorten een goed vooruitzigt. 
wegens de kleine hoeveelheid bast, niet gemakkelijk was. Er was geen chinine in, maar wel eene hars, welke onmiskenbaar den reuk en de eigenschappen van de Kina-harsen bezat, en hoog noodig nader verdiende onderzocht te worden, zoodra grootere hoeveelheid zou voorhanden zijnr.

Hij nam zich voor, om, zoodra de boomen wat ouder zullen zijn, een herhaald ouderzoek te doen (1) met cenc grootere hoeveelheid bast.

Wij merken hicrbij op, dat het tot dusverre niet bekend is, op welke periode zich in de Kina-boomen de bewuste alcaloïden ontwikkelen, en wij kunnen dus door nadere analysen omtrent het nut van den bast dezer soort, door den te regt beroemden kruidtuin der hoofdstad aan Nederlandsch Indië geschonken, welligt later gunstige mededeelingen te gemoet zien. Wij ınogen niet voorbijgaan hier aan te merken, dat zich voor onze scheikundigen in Nederlandsch Indië een nieuw veld van onderzoek opent, hetwelk van groot belang kan worden voor de zoo hoogst moeijelijke en tot dusverre nog onvolkomene sclieikundige geschiedenis der Kina-basten.

Uit den Amsterdamschen kruidtuin werden, behalve de bezendingen, welke op last van luet Ministcrie hebben plaats gehad, achtereenvolgens nog naar Oost-Indië gezonden planten van Cinchona Calisaya, als:

In April 1851 zes planten.

In December 1851 dric planten.

In Julij 1852 vier planten.

Ook de Heer J. A. Wrulink Wzn. te Amsterdam, heeft een en andermaal Cinchonen gezonden naar Java en daardoor mede van zijne dadelịke belangstelling in de goede zaak doen blijken.

(1) Later zijn de resultaten van het onderzock des Hecren Rost vas ToxNINGEN bekend gemaakt in het Nat. Tijdsehrift te Batavia. 1852. 
Reeds in April 1850 zond gemelde Heer Withink ter derde Tentoonstelling van Amsterdamsche afdeeling der Itollandsche Maatschappij van Landbouw eene plant van Cinchona Calisaya in, waarvoor hem de zilveren medaille, wegens de inzending der nieuwst ingevoerde en belangrijkste plant, werd toegeliend. Dit schijnt den Fleer WiLLisk te hebben angemoedigd om eene zending van die planten te doen naar Java aan den plantentuin te Buitenzorg, welke in 1852 heeft plaats gehad, en van welke een berigt moet voorkomen in de Java-Bode van 4 December van dat jaar, welk blad ik echter niet gezien heb. Voorts heeft de heer WiLLink in 1854 en 1855 planten gezonden van Cinchona pubescens, waarvan de resultaten nog niet bekend zijn, alzoo:

In 1852 gezonden Cinchona Calisaya.

$\begin{array}{ccc}\text { " } 1854 \text { " } 1855 \text { " } & \text { pubescens. }\end{array}$

Het blijkt uit het bovenstaande, dat de Hoofdstad in ruime mate tot de goede zank heeft bijgedragen.

In den Plantentuin te Parijs had men uit zaden van de Cinchona Calisaya door Weddel uit Zuid-Amerika gezonden, eenige plantjes zien oplkomen. Deze wareı gedecltelijk naar Algerië gezonden en aldaar omgekomen, gedeeltelijk in den tuin te Parijs verbleven. Ik zag er in 1851, in eene der kassen twee planten van, welice, naar men mij verzekerde, toen de eenige nog overgebleven voorwerpen waren. Deze voorwerpen hadden, naar ik gis, toen eene hoogte van $2-2 \frac{1}{2}$ voeten en waren in gezonden staat. Het zou onbescheiden geweest zijn een van deze twee boompjes te vragen. Ik vernam echter, dat er zich bij de IIceren Tinbaut en KeteleỀn cen voorwerp bevond, hetwelk mij bleck dezelfde soort te zijn. Deze plant is aan mij afgestaan en op 21 Julij 1851 van Parijs naar Leiden verzonden. 
Aan de heeren 'Turbaut en Kételeskn werd van hier, als equivalent voor het afstaan van dien boom, die ook met de gelijktijdige zending van andere planten gepaard ging, eene verzameling van Javaansche gewassen gegeven, waardoor het verkiojgen van onze Calisayn-kina-plant, althans geene directe geldelijke uitgaaf lıad te weeg gebragt.

De bedoelde plant groeide hier zeer welig en bereikte na eenige weken eene lengte van 75 Ned, duimen. Deze plant werd op last van Zijne Excellentie den Heer Minister van Koloniën, op der 1 sten December 1851 , in een daartoe opzettelijk vervaardigden (1) toestel naar Java gezonden en is door mij en den Hortulanus van 's Rijks Akademie-tuiu gebragt aan boord van het koopvaardij-fregat Prins Frederiti der Nederlanden, gezagroerder den Heer P. Huidekoper.

Een schrijven van den gezagvoerder in dato Batavia 21 April 1852, gaf mij te kennen dat mijne expeditic volkomen was geslaagd; hetgeen voorzeker grootendeels aan zijne naauwlettende zorgen en aan de bijzondere inrigting van den toestel, waarin de plant bevat was, scheen te zijn te danlien.

Dit vond nadere bevestiging door een schrijven van Zijne Excellentie den Grouverneur-Generaal van Neêrlandsch-Indië aan den Minister van Koloniën, in dato 23 April No. 261/8; mij, bij 's Ministers schrijven van 18 Junij 1852, lett. A, No. 5 , medegedeeld, en door een particulier schrijven aan mij gerigt, door Z. Exc. den heer Mr. A. J. Dujunaer vas Twis'r, in dato 16 Augustus 1852.

(1) Door den Hecr J. Houtz, Akademiesch Arehitect alhicr, volgens cen plan door mij en den Hortulanus ScHudruass Stekroven uitgedacht. Van dezen toestel heb ik ecne besehrijving cn afbeclding gegeven in door mij uitgegeren Tuinbouro-Flora van Nederland en zijne Overzeesehe Bezillingen. I Decl, 1 S54. p. $111 \mathrm{cn}$ aldaar mijne verhandeling: Over dusgenartmde Wrardsche locstellen en de daaraan hier acngebragte voijzigingen. 
Het zal wel geheel onnoodig zijn te verzekeren, dat ook dit voorwerp door den Heer Teissmann met de grootste zorg is behandeld, aan welke zorg zijn behoud, na de welgeslaagde overkomst op Java, is te danken. Het blijkt dat Z. E. de GouverneurGeneraal even als Z. Exc. de Minister van Koloniën groote waarde aan dit voorwerp en zijne gelukkige overbrengst hechtteden; hetgeen, onder anderen, ook is op te maken uit de erkenning welke den Heer Huısdekoper door den GouverneurGeneraal, op uitnoodiging van den Minister, voor die welgeslaagde poging werd aangeboden.

Men nam van dit boompje al dadelijk cenige stekken af, en verzekerde zich langs dien weg van het behoud dezer plant, indien ongelukkig de hoofdstam eens kwame te sterven (1), waarvoor aanvankelijk eenige vrees bestaan hceft.

De stekken groeiden en de boom bleef behouden, waarloe zeker de overbrengst naar Tjipannas, in overleg van Z. E. den Gouverneur-Generaal met den Heer Teysmans, veel heeft toegebragt.

Van de uit den Leidschen Hortus aangebragte plant zij thans dit nog bij het reeds vermelde gevoegd, dat, luidens de laatste van 0ost-Indië ontvangen berigten, van dezen boom reeds zeer gunstige vooruitzigten zijn verkr'egen voor zijne vermeerdering, terwijl het voorwerp zelf nagenoog eene hoogte van $5_{2}^{1}$ voeten bereikt heeft. (2)

Zal die kultuur op Java slagen? Zullen aldaar de grond,

(1) Brief van Zijne Excellentic den Gouverneur Generaal van Ncêrlandsch Indië, dd. $23 \Lambda$ pril 1852, No. 261/s, aan Zijne Excellentic den Heer Minister van Koloniën met 2 bijlagen, als: brief van $J$. E. Tcijsmann, in dd. $16 \Lambda$ pril, aan den Baron van Hecrdt, Kapt. Adjdt. fung. Intendt. der GouvcrmementsHôtels en eveneens in dd. 18 April van denzelfden aau den Baron van Heerdt.

(2) Zie het artikel: Kina-kultuur op Java, door G. WAssınk, in het Nat. Tijdschr. voor Nederl. Indië, III. 1852, p. 343. 
de lucht, het licht, de graad van warmte, van vochtigheid en de andere atmospherische verhoudingen, zullen eindelijk de bijzondere situatien enz. voor die kultuur geschilkt zijn? Zal de plant, in één woord, dáár vinden, wat zij in lıaar vaderland vindt, wat zịj behoeft om zich in eenen normalen staat te ontwikkelen en daarbij al datgene te vormen wat haar tot de onschatbaarste van alle geneesrijke stoffen moet maken, die de oppervlakte der aarde ergens oplevert?

Van geene enkele nieuwe landbouw-onderneming is de uitslag a priori als zelser aan te nemen. De gehcele landbouw ontstond intusschen door den ruil of de overbrengst van planten van de eene naar de andere landstreek. Dit geldt den landbouw van geheel Europa, en wij kunnen zeggen (althans voor zoo verre wij daarmede bekend zijn) ook van de andere werelddeelen, maar bovenal betreft dit de kultuur in de tropische gervesten en in Europesche lsolonisatiën in andere werelddeelen. Het talloos heir van de gewassen van oeconomischen of technischen aard behoort bijna nergens oorspronkelijk te huis in de landen waar men ze kweekt. (1)

Maar die kultuur-planten zijn juist de nultigste der geheele aarde. Men zoekt en vindt ten laatste al die onstandigheden,

(1) VoN HUMBOLDT (en wij kunnen zeker geen grootere autoriteit aanvoeren) laat zich daarover aldus uit in zijn Essai sur la géogr. des plantes, p. 27. "l'homme inquièt et laboricux en parcourant les diverses partics du monde, a "forcé un certain nombre de végétaux d'habiter tous les elimats et toutes les "hauteurs; mais cet empire excreé sur ces êtres organisés u’a point dénaturé "Icur structure prinitive. La pomme de terre cultivéc an Chili à trois mille " six cent mètres (1936 toises) de hauteur, porte la même fleur que celle que "l'on a introduite dans les plaines de la Sibéric. L'orge qui nourrissait les che"vaux d'Achille étoit saus doute; la même que nous semons aujourd'hui. Les "formes caractéristiques des végétaux et des animaux, que présente la surface " aetuelle du globe ne paraíssent aroir subi aneun changement, depuis les épo"ques les plus réculées" - etc. 


\section{5}

welke zij behoeven, en dit wel (tenzij de plant voor de verandering van lucht en grond ten eenemale, 't geen al spoedig blijkt, ongeschilit moge wezen) met weinig moeite. Meerdere planten voor den liandel op Java en van wier producten. althans van sommigen, bij ons jaarlijlss millioenen in 's lands schatkist vloeijen, zijn geene natuurlijle inboorlingen van dat schoone land, inaar werden van elders daarhenen gebragt. «De koffij b. v. (zegt vor Humboudt) is van Arabië, de indigo van Zuid-Afrika, de suiker van China, de kaneel van Ceylon, de vanielje en de nopal zijn van Mexico, de tabak is van Amerika, de rijst van China en Japan, enz." Van sommige anderen is dé herkomst niet meer aan te wijzen. Andere planten waren er wel oorspronkelijli, maar zijn toch ook van elders aangevoerd en allen slagen zij uitmuntend. Dit in details hier voor te dragen, zou leiden tot de vermelding van overbekende zaken (1).

Het heerlijke Java zou wel moeten geacht worden niet alleen hooge maar ook lagere temperaturen en velerlei klimaten te hebben, al wist men het niet door ondervinding. In een en hetzelfde eiland Java groeijen kokos-palmen en eiksoorten (2). Van zịne

(1) Von Huмвоц, zegt, t. a. p. 27. "C'est ainsi que l'homme change à soll "gré la surface du globe et rassemble antour de lui les plantes des climats les "plus éloignés. Daus les colonies Enropéennes des denx Indes un petit terrain "cultivé présente le café de l'Arabie, la camne à sucre de la Chine, l'indigo "de l'Afrique et une fonle d'autres végétanx, qui apparticnnent aux doux "lémisphères."

Anderen honden de indigo voor cene Indische plant, hocwel men uit de verschillende berigten en gevoclens mag afleiden, dat de gelicele zaak ouzcker is. Zie Roxi. 1. ind. III. 379. Wigmt et ARN. prodr. p. 202. Royds, Ill. Him. t. 195. Aph. ne Candolise Googr. bot. II. 854.

(2) C. L. Buume, over de Javaunsche ciksoorten, voorkomende in de Forh. ean Batav. genootschap van Kunston on Wetenschappen, IX 1923. Flora Javac vau

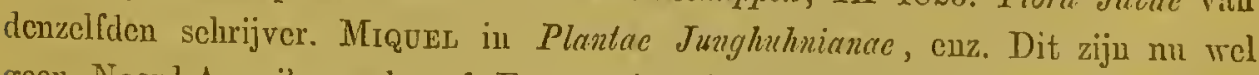
geen Noord-Amerikansele of Europesche eiksoorten of eikrormen, manr wij voeren dit slecht aan on te betoogen, welke hemelsbrecd versehillende planten- 
vlakten tot zijne verschillende hoogten vindt men al de overgangen der vegetatie, als die, welke men aantreft van den equator tot in de gematigde luchtstreken. Java levert op zijne vlakten en in al hare verscheidenheden de tropische Flora, en op zijne hoogten, zijne plateaux, zijne bergtoppen vindt men de Flora van $Z$ uid- en Midden-Europa. De vlakten van Nederland bieden in zeer vele opzigten overeenkomstige Flora's mel de meer dan 9,000 voeten hooge toppen der bergen van Java (1).

De vorderingen in onze kennis van de geographische verbreiding der planten en van de vetten, volgens welke die verbreiding plaats heeft, in verband met de kennis van de natuurlijke gesteldheid der landen, bieden eenen vasten grondslag aan voor ondernemingen van kultuur en van het overbrengen van planten, somwijlen van op duizenden mijlen afstands aangebragt.

De ligging van vele der Kina-streken in Zuid-Amerika, overeenkomstig met de geographische breedte van Java, moet niet worden uit het oog verloren. Biedt deze niet a priori eene gelijke temperatuur aan, - ten aanzien van de verdeeling der hueveelheid van het zonlicht, dien magtigen prikkel der vegetatie, zal dit toch eenige overeenkomst geven. Er is op

vol'men een en hetzelfde eiland Java, op versehillende hoogten, gerekend van de oppervlakte der zee tot op de hooge bergtoppen, oplevert.

(1) Wij verwijzen den lezer naar het uitstekende werk van Dr. Junghums, Java, zigne bekleeding, tweede druk, bij C. W. Mresing te 's Hage, enz. waar. van het laatste stuk handelt over de planten-geographic van dat eiland, in betrekking tot zijne klimatologisehe verhouding. Verder zie men, in betrekking tot dit onderwerp, vooral eehter tot de verseheidenheid der Flora's die Java op zijue versehillende hoogten aambiedt, de verhandeling van wijlen den Hoogleeraar C. G. C. REINwARDT, over de hoogte en verdere naturlijle gesteldheid van eenige bergen in de Preanger. Reyentsehappen, in de Verhandelingen ran het Batavianseh Genootsehap van Kunsten en Wetensehappen, IXde Deet. Batavia 1522, en aldaar p. 33 en 34 . 
Java bovendien eene voorname voorwaarde, die van het grootste gewigt is en den goeden uitslag bijna met zekerheid waarborgt. Zij is deze: "Van de overplanting van den Kina-boom uit zijnen geboortegrond naar een vreemd land kan alleen dan een goed resultaat verwacht worden, indien (behalve aan voorwaarden van minder gewigt) voldaan wordt aan één hoofdvereisclite, namelijk dat de boomen niet moeten geplant worden in eenig land buiten de keerkringen gelegen, dewijl alleen in de tusschen de keerkingen gelegene zone, die gelijkmatigheid van temperatuur gevonden wordt, die liet geheele jaar door nagenoeg onveranderd blijft en waarvan de vrije en natuurlijke ontwikkeling der Kina-boomen door de natuur afhankelijk gemaakt is, zoo als uit de geographische verbreiding dier boomen in Bolivië, Peru, Ecuador, Nieuw-Grenada blijkt. Hierom zullen de landen buiten de keerkringen gelegen, b. v. Algerië of het Himalaya-gebergte nooit tot de kultuur der Cinchonen kunnen dienen, als zijnde buiten de keerkringen gelegen, en alwar het jaarlijksche verschil van winter-en zomer-lemperatuur te grool is, om te kunnen veronderstellen, dat daar boomen zouden kunnen tieren, die het geheele jaar door aan een onveranderlijk klimaat gewoon zijn. (Junghums). Gelijke hoogten, met zoo veel mogelijk gelijke klimatische gesteldheid, met de variatiën vau den thermometer bij dag en bij nacht, zullen wel te vinden $\ddot{z} \ddot{j} n$. Overeenkomstige Flora's als die van de Kina-bosschen van Peru liunnen op de bergen van Java den weg, de plaats en welligt ook de gronden aanwijzen, waar men de Kina met goed gevolg zal kweeken.

Volgens het gevoelen van Dr. Jungruurs moel, men op Java, op 5,000 a 6,000 roeten of zelfs nog hooger de hoogte vinden voor de kultuur der Kina; vooral, indien men te regt bewecrt, dat de ondervinding in Amerilia zou hebben geleerd, 
dat die soorten, welke op de lagere stations overkomen, minder chinine opleveren en door de cascarilleros slechts gebruilit worden om onder de betere basten te mengen.

De aanvankelijk verkiregen ondervinding moet al darlelijk pleiten voor de juistheid der bewering van zoo vele uitstekende mannen onder onze Vaderlandsche geleerden, die zoo bij herhaling in 't belang dezer zaak hunne stemmen hebben doen hooren, en voor het regtmalig vertrouwen hetwelk in hun gevoelen werd gesteld, vooral door den tegenwoordigen Minister van Koloniën den Heer Chrs. F. Parud, onder wiens leiding deze zaak, ongetwijfeld ook tot zijne eigene voldoening, aangevangen en tot dusverre zoo gelukkig volbragt werd. Inderdaad is de kultuur reeds werkelijk geslaagd, gelijk wij meenen dat uit de boven gegeven mededeeling, maar ook bovendien uit directe berigten van Java is op te maken, luidens welke de Kina-kultuur aldaar zoo ver is gevorderd, dat men van meening is, dat die daar "NIET MEER KAN MISLUKKEN."

Men heeft alzoo deze vreemde planten geacclimateerd, vermenigvuldigd, uit zaden zien opkomen, in plantsoenen uilgeplant en dit alles met zulk een goed gevolg, dat de Kinaplantagie zich in zeer gunstigen staat bevindt.

Naar onze goede overtuiging zullen er, zonder groote en niet te voorziene rampen, na weinige jaren, op Java aanzienlijlie Kina-aanplantingen bestaan en dit wel van de beste soorten, dic Peru en Bolivië opleveren. Het aantal van de boomen waartoe die kultuur in liorte jaren kan leiden, is nict te berekenen; maar wanneer wij tot basis van berekening nemen de omstandigheid dat één boompje, 't welk drie jaren geleden op Java kwam en nu ongeveer $5_{:}^{1}$ roet hoog zijnde, reeds 60 steklingen heeft gegeven, dan zal in weinige jaren, 
bij eene evenredige voorzetting der kultuur, het getal der boomen tot eenige millioenen kunnen aangroeijen.

In de bovenstaande mededeeling zijn de feiten aangaande de overbrengst van den Kina-boom uit Zuid-Amerika naar Java, eenvoudig en naauwkeurig medegedeeld, met vermijding van al datgene, 't welk kon gerekend worden daartoe niet te behooren.

$\mathrm{Er}$ is naar gestreefd om der waarheid hulde te doen en verdiensten ran ieder, die tot deze zaak door raad of daad heeft bijgedragen, te vermelden. Ware welligt de vervulling van zoodanige taak, gelijk ik gaarne gelooven wil, van meer bevoegden en meer kundigen te verwachten geweest, ik zou toch met hescheidenlıeid meenen, door mijne middelmatige pogingen iets te hebben bijgedragen, om in hare aanleiding te doell waarderen en in eenige bijzonderheden te doen kennen de zaak der Kina-overbrengst van Zuid-Amerika naar Java, waarbij het geheele Menschdom een onberekenbaar belang heeft en door het welslagen waarvan Nederland eene regtmatige aanspraak op de hulde der beschaafde Wereld heeft verworven.

De geëerbiedigde naam van Koning WiLLem III, onder wiens Regering eene zoo nuttige en vreedzame verovering lieeft plaats gehad, die in de geschiedenis der negentiende eeuw met gulden letteren moet worden opgeteekend, zal ook daarom bij tijdgenoot en nakomcling g'ezegend zijn! 



\section{O VERZI G T.}

I. Voorrede, 1-4. - Inleiding, 5. - Eerste kennis aangaande de Kina, 8. - Tijd van invoer, 9. - Ontdekking van de Kina in Amerika, 9. - De eerste Kina, welke men leerde kennen was vermoedelijk loxa. - De Kina ingevoerd in den Kerkelijken Staat, 11. - Geschriften tegen de Kina, 11. - Geheime geneesmiddelen tegen de koorts, 12 - Talbot's arcanum, 12. - Eerste wetenschappelijke onderzoekingen, 12.-Door DE LA CONDAMine, 13. - Door Joseph de Jussieu, 16. - Door Mutts, Rutz en Pavon, 17. - Belangrijke ontdekkingen door Mutis, 18. Uitvoer uit de Noordclijke Staten van Zuid Amerika, 19. - Vermenging van basten, 19. - Minachting der Kina van NieuwGrenada, 20. - Soorten van basten, soorten van Cinçhonen, 20. - Verbreiding der Cinchonen volgens ron Humboldt, 21. Volgens Weddell, 23. - Exploitatie van de Kina, 29. - Inzameling, 30. - Ontschorssen, 31. - Droogen, 32. - Uitroer uit Bolivië, 33. - Uit Peru, 34. - Tegenstrijdige berigten, 35. De versche bast is ook koortsdrijvend, 35. - Tijdstip van inroer der soorten in den handel, volgens voN BERGEN, 38. - Karakteristiek dcr basten, volgens denzelfden, 39. - Naar uitwendige kenmerken, 39. - Naar chemische grondslagen, 40. - Methode ran Weddeld, 41. - Microscopisch ondcrzoek, 42. - De Kina in harc wanrde als gencesmiddel, 42. - Dc chinine, 45. - Cinchonine, 45. - Verdeeling der basten on soorten naar die bestanddeclen, 47. - WedDelL hecft de basten genoemd naar de botanische soortsnamen, 47. - Voornaamste soorten ran Cinchona, volgens WEDDELL, 48. - Calisaya of Konings-kina, 49. - Bevindingen van DrLondre, 49. - Gcbmik ran cone inindere hocrcclhcid chininc-bevattende basten, 51. - Calisaya van Nieuw Grenada, 51. - 
Hoogroode Kina, 52. - Loxa-kina, 52. - Huanuco-kina, 53. Roode Kina, 54. - Haar gebruik, 54. - Cinchonen zaden, in betrekking tot hetgeen de soorten, wantoc zij behooren, opleveren, 54. - Cinchona pubeseens Vahl., 54. - C. ovata $R$. \& P., 55. - C. lancifolia Mut., 58. - Cinehonen en basten vau Nicuw Grenada. Hunne groote waarde, 58. - De basten zijn wanrdiger, naarmate zij meer ehinine bevatten, 58. - Waarde van loxa- en Huanueo-kina, 59. - Van einehonine, 61. - Handel en statistiek van de Kina, 62. - In Bolivië, 63. - Statistiek van den Kina-handel in Nederland; haar gebruik, 65. - In Engeland, 67. - In Frankrijk, 68. - Algemeene resultaten afgeleid uit hetgeen aangaande de Kina bekend is, 69 .

II. Overbrengst der Kina naar Java, 71. - Teruggang der Kinabossehen in Amerika, 72. - Daaruit afgeleide noodzakelijkheid van de overbrengst naar andere landen, 79. - Aanbevelingen daartoe door Nederlandsehe geleerden, 80. - Overweging van dic voorstellen door de Hooge Regering, 81. - Vermeende onuitroerbaarheid, 81. - Proeve van invoer van de Kina in Algerië, 82.Onderlaandelingen met het Fransche Gouvernement, 82. - De kultuur in Algerië mislukt, 83. - Pogingen door Nederlandsehe Consuls enz. mislukt, 83. - De Minister van Koloniën aelit het tijdstip gekomen, om doortastende maatregelen te nemen, 84. Gevoelen van Fransehe geleerden over hetgeen men in Nederland zou kunnen doen, 85. Voorstellen door den Minister van Koloniën aan den Koning, 85. - Uitzending naar Zuid-Amerika van den Heer Hasskari, 86. - Aankomst te Panama, 87. - Payta, Lima, 87. - Het reizen over de bergen in Peru, 87. - Over de Cordillières, 87. - Eerste aansehouwing der ealisaya-boomen, 88. - Overzending van planten naar Lima, 88. - Mislukking van die zending, 88. - Aankomst der zaden, welke aan de botanisele tuinen worden gegeven om te doen kiemen, S8-59. Eigenlijke Kina-bossehen zijn er nict meer, 89. - Aankomst in Carabaya, 89. - Te Sandia, 89. - Hij ziet eene menigte soorten van Cinehonen, 90. - Terugkeer naar Lima, 90. - Reize maar het binnenland, 91. - Bolivië was afgesloten, 91. - Overeenkomst met easearilleros om Cinehona calisaya uit Bolivië te bekomen, 92. - Aankomst der planten uit Bolivie te Sandia, 93. Zij waren 4.00 in getal, 93. - Verpakking en verzending naar Islay . 94. - Mocijelijkheden en gevaren van de reize van Sandia naar de 
kust, 95. - Aankomst te Azangora, 96. - Te Arequipa, 97. - Te Islay, 98. - Inselıeping naar Callao, 98. - Vertrek van daar naar Java, 99. - Toestand der planten op de reize naar Java, 99. - Berigt van den Gouverneur-Generaal aan den Minister van Koloniën, wegens de ankomst van Hasskarl op Java, 100. - Overbrengst der planten naar Buitenzorg, 101. - De Heer HAssKarl belast net de kultuur der Kina op Java, 101. - Resultaten van de kultuur der zaden in Nederland, 101. - De zaden van Cinehona Calisaya, te regt als zoodanig door HassKarl besehouwd, 103. - De kenmerken van Calisaya, 105. - Aanvankelijke uitkomst der kultuur van zaden op Java, 106. - En. van de overgezonden planten uit Nederland, 107. - Onderseheiding door Z. M. DEN Kontsa aau den Heer Hasskarl gesehonken, 108. - Planten uit Nederland gezonden, 108. - Uit Amsterdam, 109. - C. Muzonensis, 109. De bast ontleed op Java, 109. - Andere planten uit Amsterdam, 110. - Zending van den Heer WilLtsk, 111. - Van Leiden, 111. - Vooruitzigten van de kultuur, 114. 
b. RD.YC. 221 